\title{
David Grant Medical Center Energy Use Baseline and Integrated Resource Assessment
}

\author{
E. E. Richman \\ R. K. Hoshide \\ A. L. Dittmer
}

\section{April 1993}

Prepared for

the U.S. Department of Energy

Federal Energy Management Program

under Contract DE-ACO6-76RLO 1830

Pacific Northwest Laboratory

Richland, Washington 99352

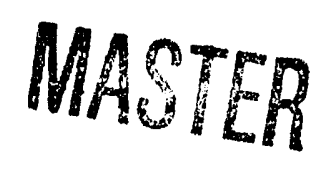




\section{Preface}

The goal of the U.S. Department of Energy (DOE) Federal Energy Management Program (FEMP) is to facilitate energy efficiency improvements at federal facilities. This is accomplished by a balanced program of technology development, facility assessment, and use of cost-sharing procurement mechanisms. Technology development focuses upon the tools, software, and procedures used to identify and evaluate energy efficiency technologies and improvements. For facility assessment, FEMP provides metering equipment and trained analysts to federal agencies exhibiting a commitment to improve energy use efficiency. To assist in procurement of energy efficiency measures, FEMP helps federal agencies devise and implement performance contracting and utility demand-side management strategies.

Pacific Northwest Laboratory (PNL)(a) supports the FEMP mission as the lead laboratory for energy systems modernization. Under this charter, the Laboratory and its contractors work with federal facility energy managers to assess and implement energy efficiency improvements at federal facilities nationwide. The U.S. Air Mobility Command (AMC) has tasked PNL to identify and evaluate all cost-effective energy rescurce opportunities at the David Grant Medical Center (DGMC) on Travis Air Force Base, California.

This report describes the methodology used to identify and evaluate the energy resource opportunities (EROs) at DGMC, provides a life-cycle cost analysis for each ERO, and prioritizes any life-cycle cost-effective EROs based on their net present value and value index.

(a) Pacific Northwest Laboratory is operated by Battelle Memorial Institute for the U.S. Department of Energy under Contract DE-AC06-76RLO 1830. 


\section{Summary}

The U.S. Air Mobility Command (AMC) has tasked Pacific Northwest Laboratory (PNL) with supporting the U.S. Department of Energy (DOE) Federal Energy Management Program's (FEMP) mission to identify, evaluate, and assist in acquiring all cost-effective energy resource opportunities (EROs) at the David Grant Medical Center (DGMC). This report describes the methodology used to identify and evaluate the EROs at DGMC, provides a life-cycle cost (LCC) analysis for each ERO, and prioritizes any life-cycle cost-effective EROs based on their net present value (NPV), value index (VI), and savings to investment ratio (SIR or ROI). Analysis results are presented for 17 EROs that involve energy use in the areas of lighting, fan and pump motors, boiler operation, infiltration, electric load peak reduction and cogeneration, electric rate structures, and natural gas supply.

The DGMC is an $820,000-\mathrm{ft}^{2}$ full-service medical facility that includes a central hospital, dental clinic, and supporting central energy plant. The facility is located at Travis Air Force Base in California for care of inpatients and for receiving earthquake casualties during and after any major seismic event. Typical current energy consumption is approximately $22,900 \mathrm{MWh}$ of electricity $(78,300 \mathrm{MBtu}), 87,600 \mathrm{kcf}$ of natural gas $(90,300 \mathrm{MBtu})$, and 8,300 gal of fuel oil $(1,200 \mathrm{MBtu})$.

A summary of the savings potential by energy-use category of all independent cost-effective EROs is shown in Table S.1. This table includes the first cost, yearly energy consumption savings, and NPV for each energy-use category. The net dollar savings and NPV values as derived by the life-cycle cost analysis are based on the 1992 federal discount rate of $4.6 \%$. The implementation of all EROs could result in a yearly electricity savings of more than $6,000 \mathrm{MWh}$ or $26 \%$ of current yearly electricity consumption. More than $15 \mathrm{MW}$ of billable load (total billed by the utility for a 12 month period) or more than $34 \%$ of current billed demand could also be saved. Corresponding natural gas savings would be 1,050 kef (just over $1 \%$ of current consumption). Total yearly net energy cost savings for all options would be greater than $\$ 343,340$. This value could be considered a conservative estimate of overall cost savings because it does not include any operations and maintenance (O\&M) savings.

Table S.1. DGMC Potential ERO Savings by Energy-use Category

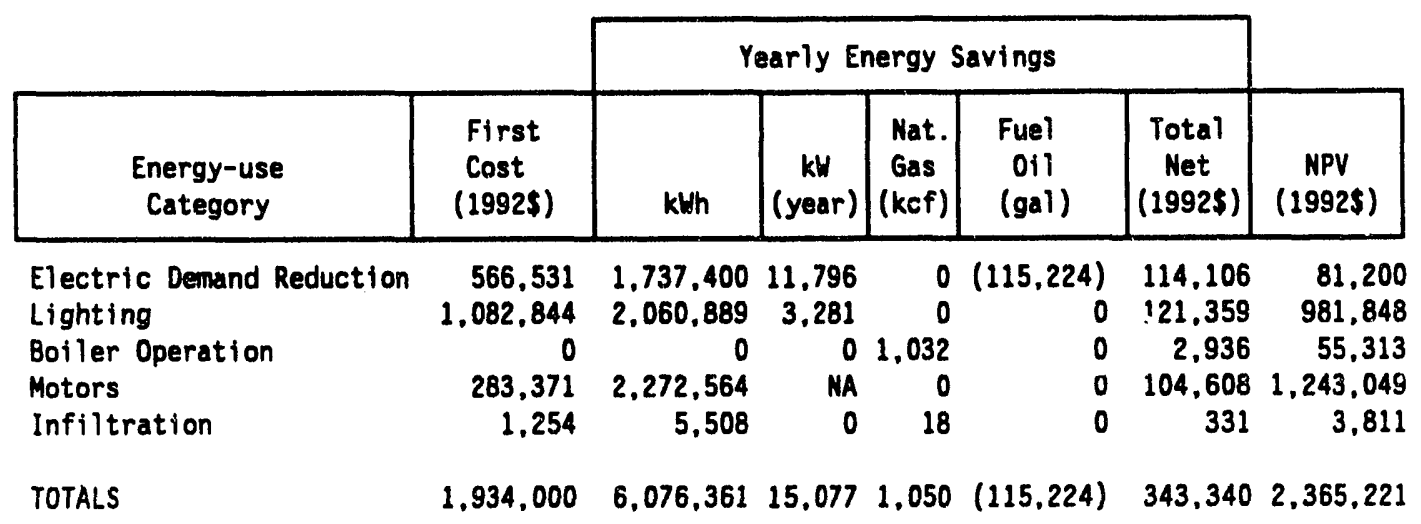


A yearly increase in fuel oil use of 115,224 gal to fire the peak-shaving generators, as well as installation costs of approximately $\$ 2.3 \mathrm{M}$, would be required to achieve this savings. Each of the energy-use categories where energy savings is available is represented by one or more individual EROs. Other EROs were found to je not cost effective.

The category of electric demand reduction includes the ERO that represents the best energysaving option of all the mutually exclusive demand-reduction options analyzed. It represents an electric demand peak-shaving system utilizing the backup generators and incorporating the use of waste heat from the generator cooling jackets. If implemented, this ERO would reduce peak electric demand by approximately $48 \%$. The lighting category represents 11 different lighting-related EROs including a variety of lighting technology retrofits, as well as daylight control and timers. These EROs, if implemented, would save $34 \%$ of the rotal lighting energy at DGMC. This represents approximately $9 \%$ of the site's total electricity use and $7 \%$ of total yearly demand. The boiler operation ERO involves adjustment of oxygen controls for natural gas savings of just over $1 \%$ of the current total use. Savings in the motors category consists of adjustable speed controls for a large number of ventilation fans. This ERO would save approximately $10 \%$ of current electricity use. The infiltration ERO involves the use of air curtain technology in loading dock areas, for an estimated savings of less than $1 \%$ of both natural gas and electric consumption.

The cost-effective EROs within each of the represented energy-use categories are summarized and ranked by VI in Table S.2. This table includes all mutually exclusive EROs. Where EROs affect the same energy use, only the one with the greatest yearly energy savings is listed.

Table S.2. DGMC ERO Summary Ranked by Value Index

\begin{tabular}{|c|c|c|c|c|c|c|c|c|c|c|}
\hline \multirow[b]{2}{*}{$\begin{array}{c}\text { Report } \\
\text { Section } \\
\text { No. }\end{array}$} & \multirow[b]{2}{*}{$\begin{array}{c}\text { ERO } \\
\text { Description }\end{array}$} & \multirow[b]{2}{*}{$\begin{array}{l}\text { First } \\
\text { Cost } \\
\text { (1992\$) }\end{array}$} & \multicolumn{5}{|c|}{ Yearly Energy Savings } & \multirow[b]{2}{*}{ NPV } & \multirow[b]{2}{*}{ VI } & \multirow[b]{2}{*}{$\begin{array}{c}\text { SIR } \\
\text { (ROI) }\end{array}$} \\
\hline & & & kWh & $\begin{array}{c}\mathrm{kH} \\
\text { (year) }\end{array}$ & $\begin{array}{l}\text { Nat. } \\
\text { Gas } \\
\text { (kcf) }\end{array}$ & $\begin{array}{c}\text { Fuel } \\
\text { oil } \\
(g a l)\end{array}$ & $\begin{array}{c}\text { Total } \\
\text { Net } \\
(1992 \$)\end{array}$ & & & \\
\hline 6.3 .1 & Boiler oxygen reset & 0 & 0 & 0 & 1.032 & 0 & 2,936 & 55,313 & NA & NA \\
\hline 6.1 .7 & Refrigeration light timers & 632 & 37.778 & NA & 0 & 0 & 1,923 & 27.400 & 43.40 & 44.35 \\
\hline 6.1 .5 & Incandescent upgrade & 2,051 & 57,494 & 102 & 0 & 0 & 3.447 & 51.609 & 25.20 & NA \\
\hline 6.1 .6 & Light intensity decrease & 438 & 23,829 & 22 & 0 & 0 & 1.033 & 10.712 & 24.50 & 25.46 \\
\hline 6.1 .8 & Daylight control (Fluor) & 3.815 & 23,884 & 55 & 0 & 0 & 1,497 & 16.447 & 4.30 & 5.31 \\
\hline 6.2 .1 & ASD fan control & 283,371 & 2.272 .564 & MA & 0 & 0 & 104,608 & $1,243,049$ & 3.78 & 5.4 \\
\hline 6.3 .2 & Air curtain & 1.254 & 5.508 & 0 & 18 & 0 & $0 \quad 331$ & 3,811 & 3.04 & 4.04 \\
\hline 6.1 .3 & 4-tube fluor. upgrade & 50,952 & 163.652 & 309 & 0 & 0 & 9,909 & 106,826 & 2.10 & NA \\
\hline 6.1 .8 & Daylight control (MH) & 6,804 & 15.186 & 35 & 0 & 0 & 950 & 11,389 & 1.70 & 4.81 \\
\hline 6.1 .3 & 3-tube fluor. upgrade & 99,682 & 209.176 & 365 & 0 & 0 & 12,512 & 118,397 & 1.19 & 8.07 \\
\hline 6.1 .3 & 2-tube fluor. upgrade & 445,543 & 902,103 & 1,592 & 0 & 0 & 54.043 & 389.500 & 0.87 & 2.99 \\
\hline 6.1 .3 & 6-tube fluor. upgrade & 54,171 & 96,458 & 135 & 0 & 0 & 5.601 & 36,477 & 0.67 & 2.74 \\
\hline 6.1 .3 & 1-tube fluor. upgrade & 407,222 & 515,538 & 650 & 0 & 0 & 29,559 & 209,993 & 0.52 & 2.69 \\
\hline 6.1 .4 & Exit sign upgrade & 11,534 & 15,791 & 16 & 0 & 0 & $0 \quad 885$ & 3,098 & 0.27 & 1.27 \\
\hline 6.4 .2 & Peak shave w/jacket cogen & 566,531 & $1.737,400$ & 11.796 & 0 & $(115,224)$ & 114.106 & 81,200 & 0.14 & 1.13 \\
\hline & TOTALS & $1,934,000$ & $6,076,361$ & 15,077 & 1,050 & $(115,224)$ & 343,340 & 2.365 .221 & & \\
\hline
\end{tabular}




\section{Contents}

Preface $\ldots \ldots \ldots \ldots \ldots \ldots \ldots \ldots \ldots \ldots \ldots \ldots \ldots \ldots \ldots \ldots \ldots \ldots \ldots$ iii

Summary $\ldots \ldots \ldots \ldots \ldots \ldots \ldots \ldots \ldots \ldots \ldots \ldots \ldots \ldots \ldots \ldots \ldots \ldots$

Acronyms $\ldots \ldots \ldots \ldots \ldots \ldots \ldots \ldots \ldots \ldots \ldots \ldots \ldots \ldots \ldots \ldots \ldots \ldots \ldots \ldots$

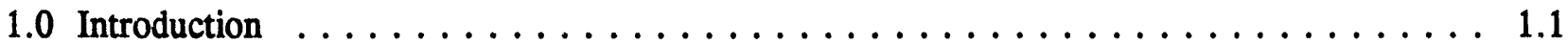

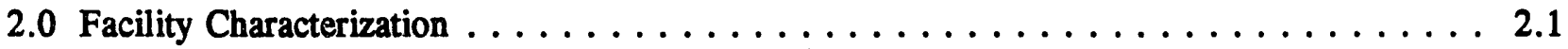

3.0 Energy Source Characteristics and Consumption $\ldots \ldots \ldots \ldots \ldots \ldots$

3.1 Electricity Supply and Consumption $\ldots \ldots \ldots \ldots \ldots \ldots \ldots \ldots \ldots \ldots$

3.1.1 Applicable Rate Configuration $\ldots \ldots \ldots \ldots \ldots \ldots \ldots \ldots \ldots \ldots \ldots$

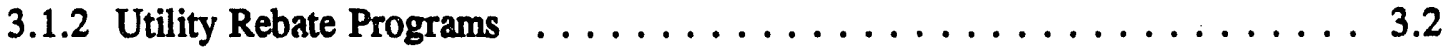

3.1.3 DGMC Electricity Consumption Characterization . . . . . . . . . 3.3

3.2 Natural Gas Supply and Consumption $\ldots \ldots \ldots \ldots \ldots \ldots \ldots \ldots$

3.3 Oil Supply and Consumption $\ldots \ldots \ldots \ldots \ldots \ldots \ldots \ldots \ldots \ldots \ldots \ldots \ldots$

4.0 Energy End-Use Allocation and Intensity Comparison $\ldots \ldots \ldots \ldots \ldots \ldots$

5.0 Selection of Energy Resource Opportunities $\ldots \ldots \ldots \ldots \ldots \ldots \ldots$

5.1 ERO Preliminary Selection Criteria $\ldots \ldots \ldots \ldots \ldots \ldots \ldots \ldots \ldots \ldots \ldots$

5.2 Master List of Screened and Selected EROs . . . . . . . . . . . . . . . . 5.3

6.0 Energy Resource Opportunity Evaluations $\ldots \ldots \ldots \ldots \ldots \ldots$

6.1 Lighting and Lighting Control EROs $\ldots \ldots \ldots \ldots \ldots . \ldots \ldots \ldots$

6.1.1 Data and Assumptions Common to All Lighting EROs $\ldots \ldots \ldots \ldots . \ldots .2$

6.1.2 Nonenergy Effects Common to All Lighting EROs . . . . . . . . . . . 6.3

6.1.3 Upgrade Fluorescent Lighting . . . . . . . . . . . . . . . . . 6.4 
6.1 .4 Upgrade Fluorescent Exit Signs . . . . . . . . . . . . . . 6.8

6.1.5 Upgrade Incandescent to Compact Fluorescent Lamps . . . . . . . . . . . 6.10

6.1 .6 Reduce Lighting Density $\ldots \ldots \ldots \ldots \ldots \ldots \ldots . \ldots \ldots . \ldots \ldots$

6.1 .7 Install Timers for Lighting $\ldots \ldots \ldots \ldots \ldots \ldots \ldots \ldots . \ldots \ldots$

6.1 .8 Install Daylight Lighting Control $\ldots \ldots \ldots \ldots \ldots . \ldots \ldots . \ldots . \ldots$

6.2 Fan and Pump Motor EROs $\ldots \ldots \ldots \ldots \ldots \ldots \ldots \ldots$

6.2.1 Install Adjustable Speed Drives for Ventilation Fans . . . . . . . . . . . 6.18

6.2.2 Install Energy-Efficient Motors for Energy Plant Pumps $\ldots \ldots \ldots \ldots . \ldots .22$

6.3 Boiler and Building Structure EROs $\ldots \ldots \ldots \ldots \ldots \ldots \ldots \ldots . \ldots \ldots$

6.3 .1 Boiler Oxygen Reset . . . . . . . . . . . . . . . . . . 6.25

6.3 .2 Instal Infiltration Air Curtain $\ldots \ldots \ldots \ldots \ldots \ldots \ldots . \ldots \ldots$

6.4 Electricity Demand-Reduction EROs $\ldots \ldots \ldots \ldots \ldots \ldots \ldots \ldots$

6.4.1 Electric Load Peak Shaving Using Emergency Generators . . . . . . . . 6.29

6.4.2 Peak Shaving with Jacket Coolant Cogeneration . . . . . . . . . . . . . 6.32

6.4.3 Peak Shaving with Jacket Coolant and Exhaust Cogeneration . . . . . . . . . . . . . . . . 6.35

6.4.4 Peak Shaving with Direct or Indirect Absorption Cooling $\ldots \ldots \ldots \ldots \ldots . \ldots \ldots$

6.4.5 Emergency Generator Fuel Switching . . . . . . . . . . . . . 6.40

6.5 Electric Rate Structure Resource Opportunity . . . . . . . . . . . . . . 6.42

6.6 Natural Gas Supply Source Resource Opportunity . . . . . . . . . . . . . . . . 6.44

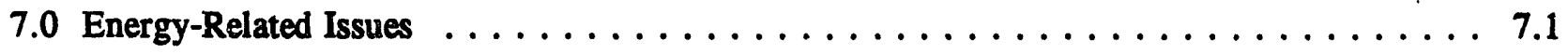

7.1 Chiller Heat Recovery $\ldots \ldots \ldots \ldots \ldots \ldots \ldots \ldots \ldots \ldots \ldots \ldots \ldots \ldots \ldots$

7.2 Energy Management Control System $\ldots \ldots \ldots \ldots \ldots \ldots \ldots \ldots \ldots \ldots$ 


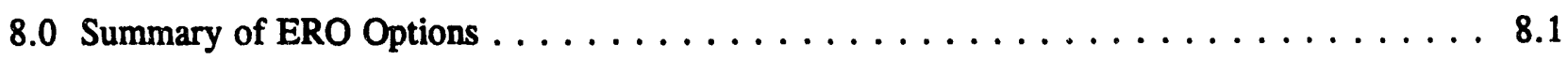

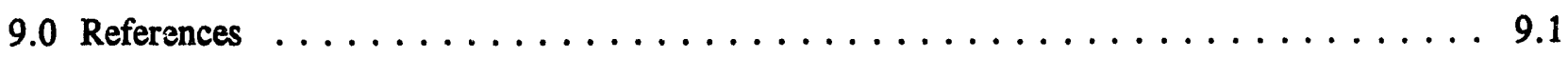

Appendix - Analysis Details and Electricity Demand Profiles . . . . . . . . . . . A.1 


\section{Figures}

A.1 " $\mathrm{Z1} 1^{\mathrm{N}}$ 24-Hour Electricity Demand Profile - Friday $\ldots \ldots \ldots \ldots \ldots \ldots \ldots$

A.2 "Z1" 24-Hour Electricity Demand Profile - Saturday $\ldots \ldots \ldots \ldots \ldots \ldots \ldots \ldots$

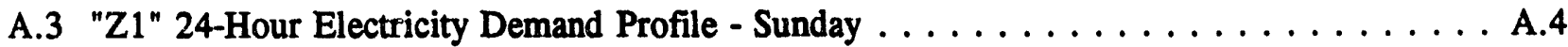

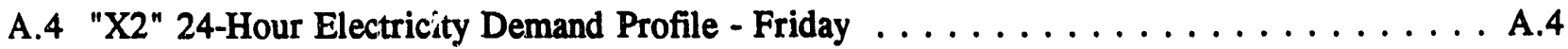

A.5 "X2" 24-Hour Electricity Demand Profile - Saturday . . . . . . . . . . . . . . A.5

A.6 "X2" 24-Hour Electricity Demand Profile - Sunday . . . . . . . . . . . . . . A.5

A.7 "Z2" 24-Hour Electricity Demand Profile - Monday/Tuesday $\ldots \ldots \ldots \ldots \ldots$

A.8 "Z3" 24-Hour Electricity Demand Profile - Wednesday/Thursday . . . . . . . . . . . A.6

A.9 "Z1" + "Z2" + "Z3" + "X2" 24-Hour Electricity Demand Profile - Weekday . . . . . . . . A.7

\section{Tables}

S.1 DGMC Potential ERO Savings by Energy-use Category $\ldots \ldots \ldots \ldots \ldots \ldots \ldots \ldots$

S.2 DGMC ERO Summary Ranked by Value Index $\ldots \ldots \ldots \ldots \ldots \ldots$

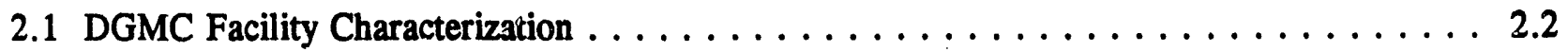

3.1 Typical Yearly DGMC Energy Consumption and Costs $\ldots \ldots \ldots \ldots \ldots \ldots$

3.2 Firm Service Rates for Primary and Transmission Service Voltages . . . . . . . . . . . 3.2

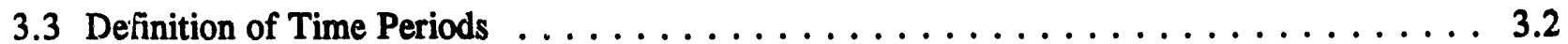

3.4 Primary Service Voltage Consumption $\ldots \ldots \ldots \ldots \ldots \ldots \ldots$

3.5 Transmission Service Voltage Consumption $\ldots \ldots \ldots \ldots \ldots \ldots \ldots \ldots$

3.6 Total DGMC Electricity Consumption $\ldots \ldots \ldots \ldots \ldots \ldots \ldots$

3.7 Natural Gas G-CS Schedule Rates $\ldots \ldots \ldots \ldots \ldots \ldots \ldots$ 
3.8 Natural Gas Yearly DGMC Consumption $\ldots \ldots \ldots \ldots \ldots \ldots \ldots$

4.1 Allocation of Energy Consumption by End Use $\ldots \ldots \ldots \ldots \ldots \ldots$

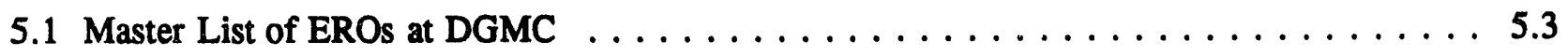

6.1 Fluorescent Lighting Fixtures at DGMC $\ldots \ldots \ldots \ldots \ldots \ldots$

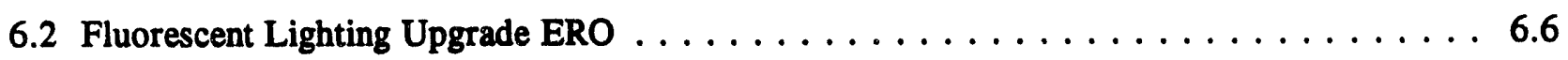

6.3 Fluorescent Exit Sign Retrofit $\ldots \ldots \ldots \ldots \ldots \ldots$

6.4 Incandescent to Compact Fluorescent Retrofit $\ldots \ldots \ldots \ldots \ldots \ldots \ldots$

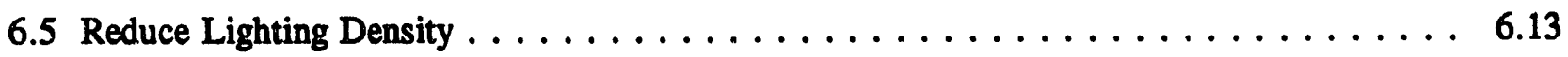

6.6 Reduce Refrigeration Lighting with Timers $\ldots \ldots \ldots \ldots \ldots \ldots$

6.7 Corridor Daylighting Control $\ldots \ldots \ldots \ldots \ldots \ldots \ldots \ldots \ldots \ldots$

6.8 Roof Top AHU Characteristics . . . . . . . . . . . . . . . . . . . 6.19

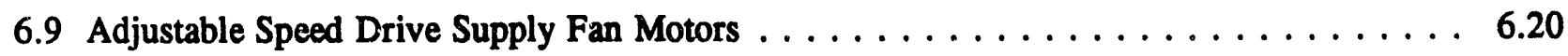

6.10 Adjustable Speed Drive Exhaust Fan Motors $\ldots \ldots \ldots \ldots \ldots \ldots \ldots \ldots$

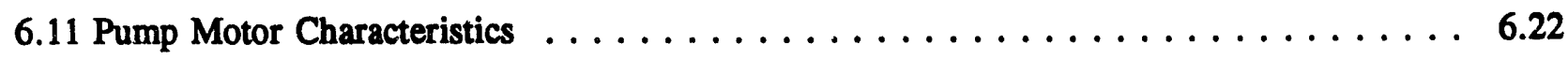

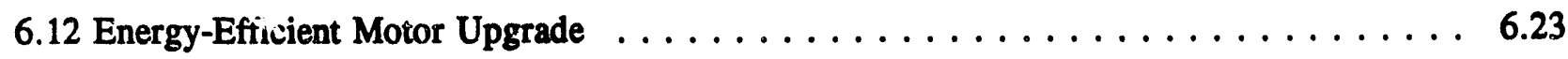

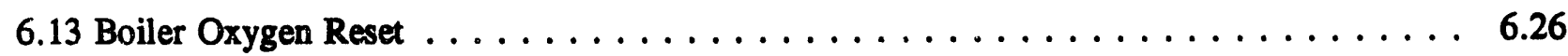

6.14 Air Curtain at Loading Door . . . . . . . . . . . . . . . . . . 6.28

6.15 Peak Shaving with Emergency Generators . . . . . . . . . . . . . . . 6.32

6.16 Peak Shaving With Jacket Waste Heat Cogeneration $\ldots \ldots \ldots \ldots \ldots . \ldots \ldots$

6.17 Peak Shaving With Jacket And Exhaust Waste Heat Cogeneration . . . . . . . . . 6.36

6.18 Electricity Savings With Direct Or Indirect Absorption Cooling . . . . . . . . . . 6.39

6.19 Peak Shaving With Natural Gas Emergency Generators $\ldots \ldots \ldots \ldots \ldots . \ldots \ldots$

8.1 DGMC ERO Summary and Ranking by Value Index $\ldots \ldots \ldots \ldots \ldots \ldots$ 
8.2 DGMC ERO Summary and Ranking by Net Present Value $\ldots \ldots \ldots \ldots \ldots$

8.3 DGMC ERO Summary and Ranking by Total Energy Savings $\ldots \ldots \ldots \ldots . \ldots$

8.4 DGMC ERO Summary and Ranking by First Cost $\ldots \ldots \ldots \ldots \ldots \ldots$ 


\section{Abbreviations and Acronyms}

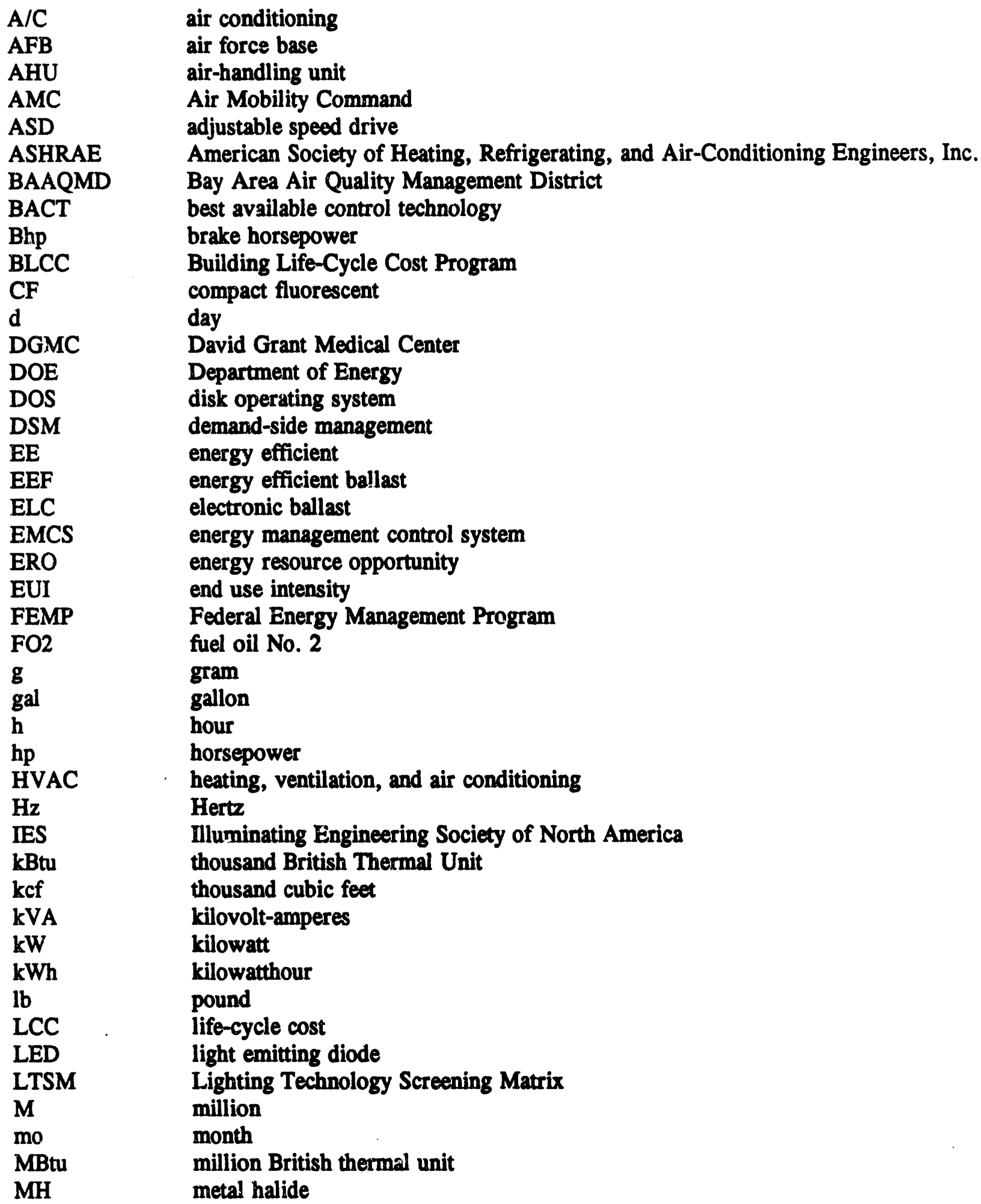




$\begin{array}{ll}\text { MW } & \text { megawatt } \\ \text { MWh } & \text { megawatthour } \\ \text { NBS } & \text { National Bureau of Standards } \\ \text { NG } & \text { natural gas } \\ \text { NIST } & \text { National Institute of Standards and Technology } \\ \text { NPV } & \text { net presant value } \\ \text { O\&M } & \text { operations and maintenance } \\ \text { oF } & \text { degrees Fahrenheit } \\ \text { PCBs } & \text { polychlorinated biphenyls } \\ \text { PCF } & \text { permanent compact fluorescent } \\ \text { PG\&E } & \text { Pacific Gas and Electric Company } \\ \text { PNL } & \text { Pacific Northwest Laboratory } \\ \text { REF } & \text { parabolic reflector } \\ \text { ROI } & \text { return on investment } \\ \text { RTU } & \text { rooftop unit } \\ \text { IPm } & \text { revolutions per minute } \\ \text { SIR } & \text { savings to investment ratio } \\ \text { V } & \text { volt } \\ \text { VI } & \text { value index } \\ \text { W } & \text { watt } \\ \text { WSEO } & \text { Washington State Energy Office } \\ \text { yr } & \text { year }\end{array}$




\subsection{Introduction}

An Executive Order on federal energy management signed April 1991 sets a goal of $20 \%$ reduction (from 1985 levels) in federal facility energy use by the year 2000 . The goal for each facility is to be achieved by the implementation of life-cycle cost-effective energy end-use technologies, using utility demand-side management (DSM) programs wherever possible. A major oustacle to reducing energy use in large federal facilities is often an inability to characterize energy consumption and energy reduction resources in sufficient detail. This often leads to only partial or incomplete energy resource assessment and project completion. In some cases, complete savings packages are pre-emptied by partial energy-saving measures.

The U.S. Air Mobility Command (AMC) tasked Pacific Northwest Laboratory (PNL) to assess the practical and achievable energy-reduction potential at the David Grant Medical Center (DGMC). This includes an energy-use baselin'; and integrated resource assessment. Once assessed, the process of acquiring funding from utility DSM programs and other sources can proceed, along with the design of specific energy projects.

This assessment report covers the energy use and reduction potential found within the boundaries of the DGMC, including the main hospital, dental clinic, and power plant. Section 2.0 presents an overview of the medical center site and facilities. Section 3.0 provides detailed descriptions of the electricity (consumption and demand), natural gas, and fuel oil supply systems and consumption characteristics at the medical center. A general comparison of the medical center's energy consumption with other similar facilities, as well as an end-use breakdown of energy consumption, is provided in Section 4.0. Section 5.0 describes the process of selection and analysis of potential energy resource opportunities (EROs). The specific assessment and life-cycle cost analysis of possible energy reduction opportunities is detailed in Section 6.0. This section also includes data assumptions, analysis results, and other pertinent information on each ERO analyzed. Some energy-related issues are discussed in Section 7.0, and a summary and ranking of all cost-effective EROs is provided in Section 8.0. References are found in Section 9.0. The appendix contains analysis details and electricity demand profiles. 


\subsection{Facility Characterization}

David Grant Medical Center (DGMC) is located on 155 acres at Travis Air Force Base (AFB), approximately 4 miles northeast of Fairfield, California, at about $38-1 / 4^{\circ}$ North and $122^{\circ}$ West. This facility was designed for medical care to inpatients and for receiving earthquake casualties during and after any major seismic event (Seismic Zone 4).

The facility includes a separate entrance, gatehouse, and complete supporting infrastructure with street and utility systems. This hospital has more than 1800 parking spaces and consists of three buildings. They are the medical center (Building No. 777), dental clinic (Building No. 775), and energy plant (Building No. 779). With more than 3400 rooms, the medical center covers a land area of almost seven football fields. The inpatient side of the structure has four stories, while the outpatient zone has three stories. An 18-ft-high berm creates a second main entrance at the south side of the hospital. It provides street-level access to high-use clinics and departments, such as the emergency room, family practice, pathology, radiology, and pharmacy. This medical center has 298 beds, 75 aeromedical staging flight beds, 52 dental treatment rooms, a hyperbaric chamber, linear accelerator, and a magnetic resonance imaging unit. This facility is designed to expand to 190 additional inpatient beds to support readiness missions. The number of occupants varies with estimates of 3000 to 4000 persons during business days and about 1500 persons during nonbusiness days and weekends.

The DGMC, completed in December 1988, was designed and built as a single megastructure. It is the first Air Force facility to incorporate the interstitial space concept, which has proven to be effective in Veterans Administration studies. The mechanical, electrical, and air-handling systems are located above each floor to facilitate maintenance and repair without interference to the hospital medical functions. The facility combines both stiel frame and concrete construction with flexibility to allow for future expansion and internal changes with minimum disruption and cost. The triangular nursing towers are structural tubes surrounded by concrete shear walls. The remaining exterior is California stucco and ceramic tile.

The main building is divided into three separate patient zones: nursing units, support/diagnostic treatment, and clinics. Each zone is served by separate system components and can function and expand independent of the other zones. These modular systems are arranged according to functional use (surgery, radiology, clinics, nursing units). These functional areas can be separated to accommodate maximum area limitations, after-hours shutdown, special conditions (surgery), or complete shutdown (repairs, closure of nursing unit or clinics during low occupancy). Main parient corridors and waiting rooms are designed around four major flow patterns (inpatient, cutpatient, staff, and materials). Courtyards provide orientation for staff and patients, natural light, and outlooks for patient rooms. All elevators are separated according to their intended use or physical location to decrease cross-contamination, disturbance to patients, and traffic congestion. A 600,000-gal water tank and a 90,000-gal sewage-holding tank provide service in the event of an emergency. The DGMC characterization for the three buildings is provided in Table 2.1. 
Table 2.1. DGMC Facility Characterization

$\begin{array}{llccc}\text { Buflding } & \text { Eneray Types } & \begin{array}{c}\text { Total } \\ \text { Floorspace } \\ \left(\mathrm{ft}^{2}\right)\end{array} & \begin{array}{c}\text { Total } \\ \text { Floorspace } \\ \text { (percent) }\end{array} \\ \text { Medical Center } & \text { Electricity/Gas } & 782.903 & 95.44 \\ \text { Dental Clinic } & \text { Electricity/Gas } & 23.597 & 2.88 \\ \text { Energy Plant } & \text { Electricity/011/Gas } & \frac{13.843}{820.343} & \frac{1.68}{100.00}\end{array}$

Utilities at DGMC include electricity, natural gas, water, and sewer. Supplies of No.2 diesel fuel oil are delivered by truck from local distributors. Electrical service is provided by Pacific Gas \& Electric Company (PG\&E) at two substations (Nos. 1 and 2), located at the east side of the energy plant. The electrical service is further distributed by five switchir. 6 stations. These stations individually serve each of the four quadrants of the hospital and the power plant. Both primary (E-20P) and transmission (E-20T) service voltages are provided on a firm service rate basis. Natural gas service is also provided by PG\&E. Charges for natural gas service under this schedule include those for customer transportation and procurement. Fuel oil is obtained from local suppliers and used as fuel backup to the energy plant as well as to supply the six emergency generators. Typical yearly energy usage based on 1991 and 1992 data is as follows:

- electricity $=22,946,000 \mathrm{kWh}$

- natural gas $=87,677 \mathrm{kcf}$

- fuel oil $=8,352 \mathrm{gal}$. 


\subsection{Energy Source Characteristics and Consumption}

Total energy consumption and costs at DGMC for March 1991 through February 1992 are summarized in Table 3.1. For each energy type, this 12-month total is shown in units appropriate to the energy type (megawatthour [MWh], thousand cubic feet [kcf], and gallon [gal]), as well as the common million British thermal unit (MBtu) for comparison. These total consumption values are based on the usage values chosen for analysis in this report as typical current yearly usage. This typical year is based on the best available data gathered from both the 1991 and 1992 consumption levels. Fuel oil consumption for this period is made up of the energy plant boilers usage (dual fuel capability check) and estimated emergency generators usage. These values are considered representative of normal medical center energy consumption.

Table 3.1. Typical Yearly DGMC Energy Consumption and Costs

\begin{tabular}{|c|c|c|c|c|c|}
\hline nergy Type & Yearly Total & $\begin{array}{c}\text { Yearly Total } \\
\text { (MBtu) }\end{array}$ & $\begin{array}{l}\text { Percent of } \\
\text { Total (\%) }\end{array}$ & $\begin{array}{c}\text { Energy Cost } \\
(19925)\end{array}$ & S per MBtu \\
\hline $\begin{array}{l}\text { Electricity } \\
\text { Natural Gas } \\
\text { No. } 2 \text { Fuel Oil } \\
\text { TOTALS }\end{array}$ & $\begin{array}{r}22,946 \mathrm{mh} \\
87,677 \mathrm{kcf} \\
8,873 \mathrm{gal}\end{array}$ & $\begin{array}{r}78,315 \\
90,307 \\
1,217 \\
169,839\end{array}$ & $\begin{array}{r}46.10 \\
53.20 \\
0.70 \\
100.00\end{array}$ & $\begin{array}{r}1,973,985 \\
249,311 \\
6,668 \\
2,229,964\end{array}$ & $\begin{array}{r}25.20 \\
2.76 \\
5.55 \\
13.13\end{array}$ \\
\hline
\end{tabular}

\subsection{Electricity Supply and Consumption}

Electricity is currently supplied to DGMC by the PG\&E utility. This section provides relevant details about applicable PG\&E rates in effect at DGMC, typical rebates offered by the utility for installation of energy conservation measures, and actual electricity and demand consumption.

\subsubsection{Applicable Rate Configuration}

The PG\&E E-20 schedule for commercial/industrial/general electrical service to customers with maximum demands of $1,000 \mathrm{~kW}$ or more is presently in effect at DGMC. Both primary (E-20P) and transmission (E-20T) service voltages are currently available at DGMC and have been used during the analysis period of March 1991 through February 1992. Only one of these voltage services is used at any one time and serves the entire medical center. For the primary voltage class, DGMC is served from a single customer substation from PG\&E's serving distribution system at 21,000 V. For the transmission voltage class, DGMC is served without transformation at $60,000 \mathrm{~V}$. The transmission service lines were installed at DGMC early in 1991 and have been used predominantly since that time. Table 3.2 summarizes the firm service rates for both primary and transmission service voltages. The time periods for the year and for the day are defined in Table 3.3. 
Table 3.2. Firm Service Rates for Primary and Transmission Service Voltages

\begin{tabular}{|c|c|c|c|c|}
\hline \multirow[b]{2}{*}{ Rate Structure Items } & \multicolumn{2}{|c|}{$\begin{array}{c}\text { Prinary Voltage } \\
\text { (E-2OP) }\end{array}$} & \multicolumn{2}{|c|}{$\begin{array}{c}\text { Transmission Voltage } \\
\text { (E-20T) }\end{array}$} \\
\hline & Summer & Winter & Summer & Winter \\
\hline $\begin{array}{l}\text { Demand Charges (per WH) } \\
\text { Maximum peak-period demand } \\
\text { Maximum denand }\end{array}$ & $\begin{array}{r}\$ 10.90 \\
\$ 3.25\end{array}$ & $\$ 3.25$ & $\begin{array}{l}\$ 9.00 \\
\$ 0.60\end{array}$ & $\$ 0.60$ \\
\hline $\begin{array}{l}\text { Energy Charges (per klwh) } \\
\text { Peak period } \\
\text { Partial-peak period } \\
\text { Off-peak period }\end{array}$ & $\begin{array}{l}\$ 0.10278 \\
\$ 0.06976 \\
\$ 0.05326\end{array}$ & $\begin{array}{l}- \\
\$ 0.05965 \\
\$ 0.05166\end{array}$ & $\begin{array}{l}\$ 0.08485 \\
\$ 0.05759 \\
\$ 0.04397\end{array}$ & $\begin{array}{l}- \\
\$ 0.04924 \\
\$ 0.04265\end{array}$ \\
\hline
\end{tabular}

Table 3.3. Definition of Time Periods

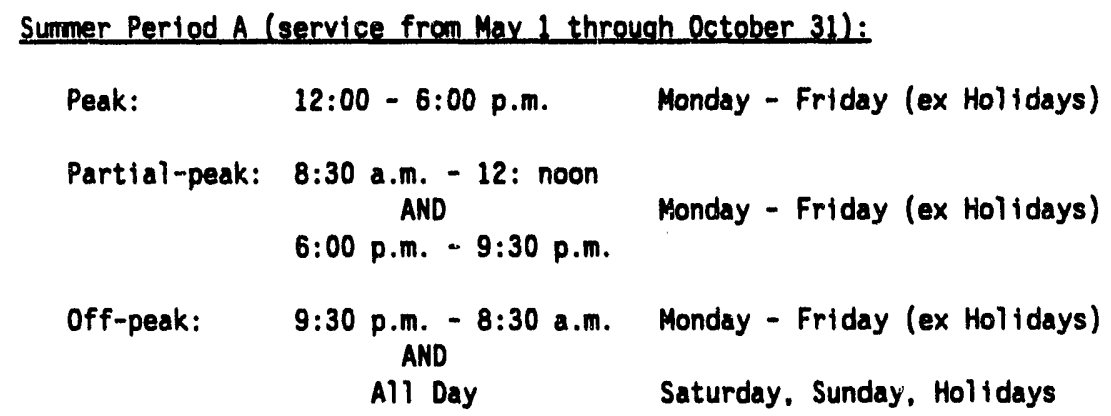

Winter Period B (service November 1 through April 30)

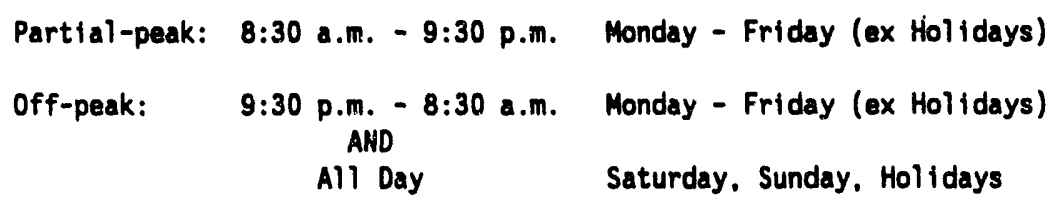

Both the primary and transmission service voltage charges were incurred by DGMC for the selected annual time period. Because the transmission rate charges are less than the primary rate charges (see Table 3.2), the hospital is now using the transmission electrical supply most of the time.

\subsubsection{Utility Rebate Programs}

PG\&E has offered a range of electric technology rebates in past and present years. These include rebates on various lighting and motor options. Because it is a relatively new facility, virtually all of the motors in use at DGMC are above or near the efficiency at which rebates are available. Many of the lighting options are applicable because lighting area technology is advancing at such a fast rate. The lighting items offered in 1992 and their incentive amounts for that year include: 
- compact fluorescent lights - $\$ 15.00 /$ complete fixture

- energy-saving fluorescent lamps - \$ 0.90/4-ft lamp

- electronic ballasts - $\$ 5.00 /$ lamp controlled

- optical reflectors - $\$ \mathbf{8 . 0 0 / 4 - f t ~ l a m p ~ r e m o v e d ~}$

- T-8 lamp/fixture retrofits - $\$ 10, \$ 25, \$ 30, \$ 35 / 1,2,3,4$-lamp kit

- lighting timers $-\$ 10.00 /$ timer.

In the past, PG\&E has also offered customized electric and natural gas cost-sharing programs. These programs have been open to any utility-approved technology other than cogeneration, wind, solar, and fuel conversions. Typical cost-sharing under these programs has been up to $50 \%$ of direct project costs.

Available 1992 specific rebate incentives are used in this report analysis to identify potential cost savings with rebates applied, assuming no up-front financing. However, as with any utility DSM prog?am, funding is usually limited and programs are not always carried from year to year. Applicable utility rebates and cost sharing must be determined and negotiated with the utility at the time that specific or site-wide projects are proposed.

\subsubsection{DGMC Electricity Consumption Characterization}

The DGMC monthly demand and consumption values for primary and transmission distribution for March 1991 through February 1992 are shown in Tables 3.4 and 3.5, respectively. Both distribution services have been utilized during the year. In some cases, zero use is recorded for one of the services when the other is exclusively used. The total DGMC demand and consumption are shown in Table 3.6. Also included is the total cost incurred for both services for that month.

Table 3.4. Primary Service Voltage Consumption

\begin{tabular}{|c|c|c|c|c|c|c|}
\hline Month, Yr & $\begin{array}{l}\text { Demand } \\
(k N)\end{array}$ & $\begin{array}{c}\text { Peak } \\
\text { Demand } \\
(k U)\end{array}$ & $\begin{array}{l}\text { Peak } \\
(\mathrm{k} / \mathrm{h})\end{array}$ & $\begin{array}{c}\text { Partial } \\
\text { Peak } \\
\text { (kWh) } \\
\end{array}$ & $\begin{array}{l}\text { Off Peak } \\
(\mathrm{k} W \mathrm{~h})\end{array}$ & $\begin{array}{l}\text { Total } \\
(k W h)\end{array}$ \\
\hline March 91 & 16 & NA & NA & 0 & 0 & 0 \\
\hline April & 0 & NA & NA & 0 & 0 & 0 \\
\hline May & 0 & 0 & 0 & 0 & 0 & 0 \\
\hline June & 4,028 & 4,028 & 228,960 & 233,2804 & 617,760 & $1,080,000$ \\
\hline July & 4,504 & 4.504 & 450,256 & 69.192 & $1,184,552$ & $2,104,000$ \\
\hline August & 3,976 & 3.976 & 458,380 & 492,492 & $1,181,128$ & $2,132,000$ \\
\hline September & 4,120 & 4.120 & 448,272 & 468,648 & $1,347,080$ & 2.264 .000 \\
\hline October & 3.981 & 3,981 & 455,820 & 492,200 & $1,191,980$ & $2,140,000$ \\
\hline November & 3,333 & NA & NA & 524,948 & 527,052 & $1,052,000$ \\
\hline December & 3,326 & MA & NA & 722,352 & $1,065,648$ & $1.788,000$ \\
\hline January 92 & 3,204 & NA & NA & 735,184 & 948,816 & $1.584,000$ \\
\hline February & 3,420 & NA & NA & 741,108 & $1,070,892$ & $1,812,000$ \\
\hline
\end{tabular}


Table 3.5. Transmission Service Voltage Consumption

\begin{tabular}{|c|c|c|c|c|c|c|}
\hline Month, Yr & $\begin{array}{l}\text { Demand } \\
(k Y)\end{array}$ & $\begin{array}{l}\text { Peak } \\
\text { Demand } \\
\text { (kU) }\end{array}$ & $\begin{array}{l}\text { Peak } \\
(k \cup h)\end{array}$ & $\begin{array}{c}\text { Partial } \\
\text { Peak } \\
\text { (kWh) }\end{array}$ & $\begin{array}{c}\text { Off Peak } \\
(\mathrm{k} W \mathrm{~h})\end{array}$ & $\begin{array}{c}\text { Total } \\
\text { (kth) }\end{array}$ \\
\hline March 91 & 3.174 & NA & NA & 718,542 & $1,000,458$ & $1.719,000$ \\
\hline April & 3,321 & NA & NA & 813.582 & 947,418 & $1,761,000$ \\
\hline May & 3.756 & 3.702 & 305,892 & 504.546 & 947.562 & $1,758,000$ \\
\hline June & 0 & 0 & 198,162 & 191,799 & 519,039 & 909,000 \\
\hline July & 0 & 0 & 5.313 & 3.780 & 11,907 & 21,000 \\
\hline August & 0 & 0 & 3.633 & 4.389 & 12.978 & 21,000 \\
\hline September & 0 & 0 & 3.255 & 3,855 & 13,860 & 21.000 \\
\hline October & 0 & 0 & 3.654 & 4.410 & 12,936 & 21,000 \\
\hline November & 0 & NA & NA & 251,505 & 477,495 & 729,000 \\
\hline December & 0 & MA & NA & 2.718 & 3.282 & 6,000 \\
\hline January 92 & 0 & NA & NA & 1.392 & 1.608 & 3.000 \\
\hline February & 0 & MA & NA & 6.216 & 14,784 & 21.000 \\
\hline
\end{tabular}

Table 3.6. Total DGMC Electricity Consumption (Primary and Transmission)

\begin{tabular}{|c|c|c|c|c|c|c|c|}
\hline Month, $Y_{r}$ & $\begin{array}{l}\text { Demand } \\
\text { (kV) }\end{array}$ & $\begin{array}{c}\text { Peak } \\
\text { Deinand } \\
(k H)\end{array}$ & $\begin{array}{l}\text { Peak } \\
(k \text { k h) }\end{array}$ & $\begin{array}{c}\text { Partial } \\
\text { Peak } \\
(k: h)\end{array}$ & $\begin{array}{c}\text { Off Peak } \\
(k \text { k })\end{array}$ & $\begin{array}{l}\text { Total } \\
(\mathrm{k} t h) \\
\end{array}$ & $\begin{array}{c}\text { Total } \\
\text { Cost }(\$)\end{array}$ \\
\hline March 91 & 3.190 & NA & NA & 718,542 & $1,000,458$ & $1,719,000$ & 184,305 \\
\hline April & 3.321 & NA & MA & 813,582 & 947,418 & 1.761 .000 & 177,065 \\
\hline May & 3,756 & 3.702 & 305.892 & 505,546 & 947.562 & 1.758 .000 & 170.926 \\
\hline June & 4,028 & 4.028 & 427,122 & 425,079 & $1,136,799$ & $1,989,000$ & 180,404 \\
\hline July & 4,504 & 4,504 & 455,569 & 472,972 & $1,196.459$ & $2,125,000$ & 205,949 \\
\hline August & 3.976 & 3.976 & 462,013 & 496,881 & $1.194,106$ & $2,153,000$ & 200,896 \\
\hline September & 4.120 & 4.120 & 451,527 & 472.533 & $1,360,940$ & $2.285,000$ & 208.878 \\
\hline October & 3.981 & 3.981 & 459,474 & 496.610 & $1,204,516$ & $2,161,000$ & 201.138 \\
\hline November & 3,333 & NA & NA & 776,453 & $1,004,457$ & 1.781 .000 & 118,254 \\
\hline December & 3.326 & NA & NA & 725,070 & 1.068 .930 & $1.794,000$ & 110,974 \\
\hline January 92 & 3.204 & MA & MA & 636,576 & 950.424 & $1,587,000$ & 101,012 \\
\hline February & 3,420 & NA & NA & 747,324 & $1,085,676$ & $1.833,000$ & 114.184 \\
\hline Totals & 44,159 & 24,311 & $2,561,597$ & $7,286,168$ & $13,098,235$ & $22,946,000$ & 1.973 .985 \\
\hline
\end{tabular}

From Table 3.6, the following information was obtained:

- percent peak $\mathrm{kWh}=11.2 \%$

- percent part peak $\mathrm{kWh}=31.7 \%$

- percent off-peak $\mathrm{kWh}=57.1 \%$

- average total cost (including demand) or "blended" cost per $\mathbf{k W h}=\$ 0.086$.

A characterization of the electric demand profile for the motor control centers serving the central plant can be found in the Appendix. These data provide some detail concerning the shape of the demand profile for major equipment. 
In addition to the PG\&E-supplied electricity, six emergency diesel engine generators located at the energy plant provide a standby source of electrical power for the hospital complex in the event of an interruption of electrical service. Each generator is rated at $600 \mathrm{~kW}$ with 0.8 power factor, 750 $\mathrm{kVA}, 3$ phase, $60 \mathrm{~Hz}$, and 1,800 rpm. These units are considered by DGMC to be "Class C" plants, according to Air Force regulations, and are rated for a maximum use of $1000 \mathrm{~h} / \mathrm{yr}$. Emergency electrical power is generated at $4,160 \mathrm{~V}$ and distributed directly to four energy plant chillers and to five unit substations. These units are normally operated $1 \mathrm{~h} / \mathrm{wk}$ at no load and $2 \mathrm{~h} / \mathrm{mo}$ under load for testing and operational status only.

\subsection{Natural Gas Supply and Consumption}

Natural gas is supplied to DGMC through PG\&E. It is supplied at the noncore commercial/industrial customer schedule (G-CS). Table 3.7 summarizes the customer, transportation, procurement, and transportation shrinkage charges under the G-CS schedule.

Table 3.7. Natural Gas G-CS Schedule Rates

1. Customer Charge:

$0-5,000$ therm

$5,001-10,000$ therm

$10,001-50,000$ therm

50,001 - 200,000 therm

$200,001-1,000,000$ therm

$1,000,001$ therm and above

2. Iransportation Charqe:

For gas delivered in the current billing month (per therm):

Sumer (April 1 - October 31)

Winter (November 1 - March 31)

$=\$ 0.12016$

$=\$ 0.13724$

3. Procurenent Charqe:

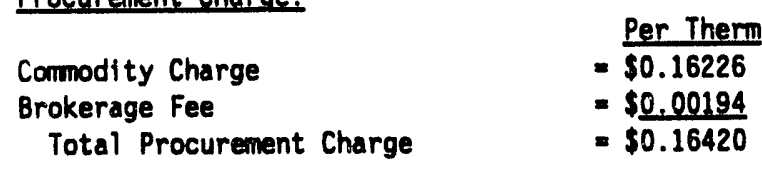

4. Iransportation Shrinkage Charae:

For gas delivered in the current billing month (per therm): 0.035 times the Commodity charge

The natural gas system supplies gas to the energy plant's three steam boilers, hospital incinerators, laboratory, and shop areas throughout the hospital. Four gas meters (GM-101, GM-1001, GM-1002, and GM-1003) measure gas use. Meter GM-101 supplies the hospital incinerator and other minor equipment in the following areas: 
- Frozen Section Laboratory

- Allergy-Dermatology-Immunization Laboratory

- Hematology-Oncology Laboratory

- Urology Laboratory

- Pediatric Hematology Laboratory

- Environmental Health Laboratory

- Bioenvironmental Engineering

- Dental Clinic

- Oral Surgery

- Nuclear Medicine

- Pathology

- Clinical Investigation Facility (CIF)

- Medical Equipment Repair Center

- Therapeutic Radiology.

The other three meters (GM-1001, GM-1002, and GM-1003) are used to measure gas use for steam boilers B-1001 (125 Bhp), B-1002 (500 Bhp), and B-1003 (500 Bhp), respectively.

Table 3.8 summarizes the gas consumption in thousand cubic feet (kcf) with the total price paid for this fuel source.

Table 3.8. Natural Gas Yearly DGMC Consumption (kcf)

\begin{tabular}{|c|c|c|c|c|c|}
\hline \multirow[b]{2}{*}{ Month } & \multicolumn{4}{|c|}{ Meter } & \multirow[b]{2}{*}{ Totals } \\
\hline & GH-1001 & $6 M-1002$ & $84-1003$ & $G M-101$ & \\
\hline March 91 & 1.2 & 7.433 .3 & 128.8 & 76.0 & 7.639 .3 \\
\hline April & 96.2 & 4.804 .9 & 3.514 .4 & 193.0 & $8,608.5$ \\
\hline May & 20.8 & 4.206 .4 & 2.135 .5 & 112.8 & 6.475 .5 \\
\hline June & 2.5 & 5.515 .0 & 36.3 & 160.7 & 5.714 .5 \\
\hline July & 21.1 & $2,808.4$ & $3,790.0$ & 102.3 & $6,721.8$ \\
\hline August & 42.3 & $3,901.9$ & 1.426 .2 & 179.8 & $5,550.2$ \\
\hline September & 48.0 & $1,556.5$ & $4,163.3$ & 156.8 & 5.924 .6 \\
\hline October & 148.3 & $3,683.2$ & $1,371.6$ & 110.7 & $5,313.8$ \\
\hline November & 58.3 & 5.425 .4 & $2,002.8$ & 153.9 & 7.640 .4 \\
\hline December & 101.8 & $4,357.0$ & 1.914 .4 & 59.1 & 6.432 .3 \\
\hline January 92 & 238.4 & 10.824 .2 & 398.8 & 210.3 & $11,671.7$ \\
\hline February & 222.2 & 2.791 .5 & $6,839.0$ & 132.5 & $9,985.2$ \\
\hline $\begin{array}{l}\text { Total (kcf) } \\
\text { Total (\$) }\end{array}$ & $\begin{array}{l}1.001 \\
2.847\end{array}$ & $\begin{array}{r}57.308 \\
162.954\end{array}$ & $\begin{array}{l}27,721 \\
78,825\end{array}$ & $\begin{array}{l}1,648 \\
4,686\end{array}$ & $\begin{array}{r}87,678 \\
249,311\end{array}$ \\
\hline
\end{tabular}

Of the total consumption, only $1.9 \%$ is used for incinerators, miscellaneous laboratory equipment, and burners, with the remaining $98.1 \%$ used for space heating, water heating, and cooking. The average cost per therm over the 1991-1992 period was $\$ 0.284$. 


\subsection{Oil Supply and Consumption}

Fuel oil Nc. 2 is supplied to the base by local distributors on a tank fill basis at a cost of $\$ 0.76 /$ gal based on a negotiated contract. This fuel oil is used primarily for operation of the six 860net brake horsepower (Bhp) diesel engines that drive the emergency generators, as well as backup to the dual-fuel central boilers. Fuel storage for the emergency generators consists of two 25,000-gal fuel tanks located at the west yard of the energy plant. Additional floot-mounted, 400-gal day tanks are located adjacent to each generator. Fuel storage for the steam boilers consists of one aboveground 25,000-gal fuel tank also located at the west yard of the energy plant. The fuel oil consumed by the three steam boilers in the energy plant is used during dual fuel operational checks. The boiler operational logs show fuel consumption as follows:

\begin{tabular}{|c|c|c|}
\hline Boiler & Month & Gallons \\
\hline GM-1001 & August 91 & \\
\hline GM-1002 & July 91 & 206 \\
\hline GM-1003 & August 91 & 15 \\
\hline
\end{tabular}

Total for the year 421

The emergency generator units are operated once a week for 1 hour without load and once a month for 2 hours with load to meet the hospital's emergency generator test requirements. Fuel oil use for these generators is estimated as follows:

No load:

$$
\begin{array}{r}
6 \text { units * } 9 \mathrm{gal} / \mathrm{h} \text { ounit } * 40 \mathrm{wk} / \mathrm{yr} * \\
1 \mathrm{~h} / \mathrm{wk}=2,160 \mathrm{gal} / \mathrm{yr}
\end{array}
$$

With load:

$$
\begin{array}{r}
6 \text { units * } 43 \mathrm{gal} / \mathrm{h} \text {-unit } * 12 \mathrm{wk} / \mathrm{yr} * \\
2 \mathrm{~h} / \mathrm{wk}=6,192 \mathrm{gal} / \mathrm{yr} \\
\text { TOTAL }=8,352 \mathrm{gal} / \mathrm{yr}
\end{array}
$$

The total annual fuel oil consumption for the 12-month period of March 1991 through February 1992 is estimated at $8,773 \mathrm{gal}(1,217 \mathrm{MBtu})$ valued at $\$ 6,668$ at $\$ 0.76 / \mathrm{gal}$. Fuel oil represents only $0.7 \%$ of the total energy use at DGMC. 


\subsection{Energy End-Use Allocation and Intensity Comparison}

The total yearly medical center energy consumption of $169,839 \mathrm{MBtu}$ can be further divided among major end uses. This division is often useful in identifying opportunities for energy improvement and assessing the reasonableness of proposed EROs. Although proposed energy improvements are based on actual site-collected data and specific analysis, the energy consumption split by end use is useful in ensuring reasonable results.

For reference, the estimated allocation of energy by major end use $s$ presented in Table 4.1. Tnese consumption values represent a "best estimate" of the actual consumption at DGMC for major end uses.

Table 4.1. Allocation of Energy Consumption by End Use

\begin{tabular}{|c|c|c|c|c|}
\hline End Use & $\begin{array}{l}\text { Percent of } \\
\text { Electricity }\end{array}$ & $\begin{array}{l}\text { Percent of } \\
\text { Natural Gas }\end{array}$ & $\begin{array}{c}\text { Percent of } \\
011\end{array}$ & $\begin{array}{l}\text { Percent of } \\
\text { All Fuels }\end{array}$ \\
\hline $\begin{array}{l}\text { Lighting } \\
\text { Heating/Water Heating } \\
\text { Cooling/Ventilation } \\
\text { Power Generation } \\
\text { Miscellaneous }\end{array}$ & $\begin{array}{r}26 \\
0 \\
48 \\
0 \\
26\end{array}$ & $\begin{array}{r}0 \\
98 \\
0 \\
0 \\
2\end{array}$ & $\begin{array}{r}0 \\
5 \\
0 \\
95 \\
0\end{array}$ & $\begin{array}{l}12 \\
52 \\
22 \\
<1 \\
13\end{array}$ \\
\hline
\end{tabular}

The lighting value is based on inventories of interior lighting fixtures, wattage, and estimated on times. A similar estimate for exterior lighting was added to arrive at an overall lighting estimate. The cooling and ventilation value is similarly derived based on inventories of the existing equipment and run time estimates. The remaining electrical energy is allocated to all other uses. The natural gas values are based on the metered consumption at each boiler and the hospital. Oil values are derived from recorded fuel use at boilers and calculations of emergency generator run times. Each of these values is within reasonable limits of standard accepted industry estimates for these uses and considered applicable to the medical center.

Sometimes, it is also useful to compare a facility's energy use with that of other similar facilities in order to assess potential for savings. Care must be taken, however, to assure that the comparison is valid. Factors such as varying climate, operational differences, and age all contribute to energy use and must be considered. A standard comparison format for building energy is the energy-use intensity (EUI) in units of energy per square foot per year (e.g., kBtu/ft'-yr). This value can be used to normalize energy use of different buildings by applying it on a square footage basis. The EUI value calculated for DGMC is

$$
\text { EUI }=(169,839,000 \mathrm{kBtu} / \mathrm{yr}) / 820,343 \mathrm{ft}^{2}=207 \mathrm{kBtu} / \mathrm{ft}^{2} \cdot \mathrm{yr}
$$

National aggregated hospital EUI ranges taken from the Washington State Energy Office (1991) publication Commercial Energy Auditing: Getting Organized were used for comparison with this 
calculated value. These ranges are

- above median $=363$ to $413 \mathrm{kBtu} / \mathrm{ft}^{2} \cdot \mathrm{yr}$

- below median $=225$ to $363 \mathrm{kBtu} / \mathrm{ft}^{2} \cdot \mathrm{yr}$.

After comparing these national values with the DGMC EUI (207 $\left.\mathrm{kBtu} / \mathrm{ft}^{2} \cdot \mathrm{yr}\right)$, the DGMC facility appears to be even more efficient than the lowest below-median value $\left(225 \mathrm{kBtu} / \mathrm{ft}^{2} \cdot \mathrm{yr}\right)$. This may be due to many factors, including:

- efficient hospital equipment and operation

- mild climate

- inherent efficiency of newer hospital.

Although not conclusive, this comparison does give an indication that there are probably no major deficiencies or losses in the standard energy flow of the hospital. However, because this is a relatively new facility, and is expected to be more efficient than a national aggregate, the possibility of energy improvements should not be ruled out. Virtually every facility has some cost-effective energy savings that can be acquired with appropriate technologies, administration, and investment. 


\subsection{Selection of Energy Resource Opportunities}

The DGMC was completed in December 1988 and the design is state of the art. Most of the equipment is already energy efficient, and the lighting levels are currently at the mid to lower end of the Illuminating Engineering Society (IES) of North America recommendations. However, potential EROs that can save energy and energy costs for the hospital were identified. Some of the EROs could have a relatively large impact on energy consumption. Others are considered "low incidence" because a very small fraction of the site energy use may be eliminated. These EROs are still costeffective energy-reduction strategies and should be considered. Like all changes in facility energy use, the health, comfort, and safety of the occupants must be maintained or improved in the selection of potential EROs.

A three-part process was used to make the ERO selection, evaluation, and prioritization manageable.

Preliminary Screening. PNL selected promising EROs from a master list of possible EROs. Consideration was given to the site's mission, building characteristics, existing equipment types and performance, utility rate structure, climate, energy types, and other site-specific conditions that affect ERO viability.

Cost and Performance Analysis. PNL established, with a reasonable degree of accuracy, the technical and economic feasibility of each ERO that passed the preliminary screening. An analysis was performed comparing the operating and economic performance of the existing equipment and the ERO. Where applicable, impacts on energy security and the environment were included in the analysis.

Life-Cycle Cost Analysis and Prioritization of EROs. PNL performed a life-cycle cost analysis as required by 10 CFR Part 436 and determined the NPV of the technology options for each ERO. The NPV was used to identify the best energy-saving technology for the ERO (highest NPV). PNL prioritized the EROs based on their energy-saving capability versus the dollar expenditure required using the VI. The VI is a ratio of NPV divided by installation cost. A ranking of EROs by the VI identifies the order in which EROs might be completed to maximize the benefits of limited dollar resources.

A primary purpose for the identification and prioritization of all major EROs at a site is the acquisition of available funding sources, including utility DSM funding. Many electric service utilities offer DSM programs that are sources of up-front financing and/or incentives for energysaving improvements. Programs vary from specific dollar rebates for installation of specific equipment to custom programs based on total site consumption and demand reduction (see Section 3.1.1 for PG\&E programs).

The remainder of Section 5.0 describes the process used for preliminary selection of EROs and 
presents a master list of screened and selected EROs. The technical and cost assumptions, impacts, and results of the life-cycle cost analysis and ERO prioritization process are detailed in Section 6.0.

\subsection{ERO Preliminary Selection Criteria}

The ERO selection process tests the applicability of a long list of EROs (see Table 5.1) using a set of rational criteria that can be applied with relatively little "hard data." This step filters out EROs that are unlikely to be economically feasible, or have significant and persistent energy impact at the site, making them not cost effective for further analysis. The eight basic criteria used to characterize and select possible EROs are listed below.

Low Incidence. EROs that apply to end-use equipment representing a very small fraction of site energy use may be eliminated. However, such EROs can be retained where the end use is concentrated, rather than diffused, or where it has previously been identified in a detailed audit and passed the other criteria without difficulty.

Economic Feasibility. A preliminary assessment of economic feasibility can often be made. EROs, whose costs and performance are well established and fairly uniform across applications, can be screened with respect to the utility's marginal energy supply cost (cost to purchase or produce).

Technical Feasibility. Sometimes, conditions at the site will preclude implementation of a certain ERO. Conditions that make retrofit difficult, or use patterns that complicate operation or maintenance of the equipment in question, may result in elimination of an ERO prior to formal analysis.

Primarily O\&M. A measure that is only a no- or low-cost change in operation or maintenance activity will generally be rejected as inappropriate to the integrated resource acquisition program. Cases where initial O\&M functions will have immediate energy reduction effects may be analyzed.

Mission Critical. Equipment that serves mission-critical areas may not be accessible for retrofit or replacement. The operation may be so critical to mission objectires that any change in the service provided is not tolerable.

Site Preference. The site may have particular objections to certain EROs based on O\&M or other infrastructure support requirements, or on unfavorable past experience, with similar measures. In cases where the ERO appears to be very attractive in other respects, it may be analyzed because the savings might incite a reevaluation of the measure.

Insufficient Data. Sometimes, the performance or operational characteristics of existing end-use equipment is unknown and the cost to determine these characteristics cannot be justified. 
Complexity. Sometimes, the complexity of the analysis precludes the analysis of an ERO as part of a comprehensive site assessment program.

Immature Technology. Some retrofit equipment has not achieved sufficient market acceptance or penetration in the federal sector to be considered reliable and effective in the field. The persistence for savings and the sensitivity of savings to O\&M, and the tendency of equipment to degrade in energy performance while continuing to operate, are factors that could disqualify a technology. Usually, such measures will not be considered.

Other ERO Dependent. A ricasure may be rejected because it depends on one or more other EROs that have been rejected or whose feasibility is too uncertain. It may also be rejected because it has already been implemented for a majority of existing end-use opportunities.

\subsection{Master List of Screened and Selected EROs}

A master list of generic conse:vation measures, aggregated from a variety of sources, was used as an origination point in the identification of EROs at DGMC. This master list is presented in Table 5.1. For each ERO listed, there is an indication of whether or not it passed the preliminary selection process. If the ERO did not pass, a brief explanation is provided.

Table 5.1. Master List of EROs at DGMC

\begin{tabular}{|c|c|c|c|}
\hline ERO Name & ERO Description & $\frac{\text { Evaluated }}{(Y / N)}$ & Comment \\
\hline \multicolumn{4}{|l|}{ FANS AND FAN MOTORS } \\
\hline Align sheaves & $\begin{array}{l}\text { Align sheaves and shafts; replace belt } \\
\text { with high-efriciency belt(s). }\end{array}$ & N & $\begin{array}{l}\text { This is primarily an } \\
\text { O\&M measure }\end{array}$ \\
\hline Reduce hours & $\begin{array}{l}\text { Install clock, EMCS switch, or other } \\
\text { control means to reduce operating hours. }\end{array}$ & $N$ & Previously tried \\
\hline Efficient motor & $\begin{array}{l}\text { Replace motor with high-efficiency model } \\
\text { and reduce size if appropriate. }\end{array}$ & $N$ & $\begin{array}{l}\text { Motors are high- } \\
\text { efficiency }\end{array}$ \\
\hline Two-speed motor & $\begin{array}{l}\text { Replace existing motor with two-speed } \\
\text { motor and controller. }\end{array}$ & $\mathbf{N}$ & $\begin{array}{l}\text { Adjustable speed drive } \\
\text { preferred }\end{array}$ \\
\hline Adjustable speed drive & $\begin{array}{l}\text { Install adjustable frequency motor drive } \\
\text { and control to modulate airflow; also } \\
\text { reduce motor size if appropriate. }\end{array}$ & $Y$ & \\
\hline $\begin{array}{l}\text { Adjustable-speed, } \\
\text { elactronically commutated } \\
\text { motor }\end{array}$ & $\begin{array}{l}\text { Replace existing motor with adjustable- } \\
\text { speed electronically comimutated permanent } \\
\text { magnet motor and control; also reduce } \\
\text { motor size if appropriate. }\end{array}$ & N & $\begin{array}{l}\text { Most fans are single } \\
\text { zone }\end{array}$ \\
\hline
\end{tabular}


Table 5.1. (contd)

ERO Name

CO2 sensor

Duct transitions

Duct cross-section

Face velocity

PUMPS AND PUMP MOTORS

Align shafts

Reduce hours

Efficient motor

Trim impeller

Two-speed motor

Adjustable speed drive

Adjustable-speed. electronically cormutated motor

Pipe transitions

Pipe size

Fittings
ERO Descriotion

Install CO2 sensors for ventilation control to reduce heating of outside air and air volume moved by fans.

Redesign duct transitions to reduce friction loss by using turning vanes, long radius turns, and gradual changes in cross-sectional area.

Increase duct cross-section to reduce friction loss.

Redesign filters, coils, etc. to reduce friction loss by operating at lower face velocities.

Align shafts and replace coupling with high-efficiency coupling.

Install clock, EMCS switch, or other control means to reduce operating hours.

Replace motor with high-efficiency model.

Replace (or trim) impeller and reduce motor size to match actual load.

Replace existing motor with two-speed motor and controller.

Install adjustable frequency motor drive and control to modulate fluid flow; also reduce motor size if appropriate.

Replace existing motor with adjustablespeed electronically commutated permanent magnet motor and control; also reduce motor size if appropriate.

Redesign system with long radius elbows and other low-loss type fittings to reduce friction loss.

Redesign system with increased pipe dianeter to reduce friction loss.

Redesign filters, heat exchangers, and valves to reduce friction loss by operating at lower velocity.

Eveluated

$(Y / N)$

N

Not advisable for hospital

N

Not applicable

N Not applicable

N Not applicable

N

Most pumps operate on demand

$Y$

N Insufficient data

N

N Most pumps operate on demand

N Incorporated into design

$N$ Incorporated into design

N Incorporated into design 
Table 5.1. (contd)

ERO Name

\section{REFRIGERATORS \\ Efficient refrigerator \\ COMMERCIAL LIGHTING \\ Upgrade fluorescent to \\ higher efficiency \\ De-lamp}

Upgrade incandescent to PCF fixture

Replace fluorescent exit signs

Reduce lighting density

Timers

Occupancy sensors

Daylight sensor

EMCS control

EXTERIOR LIGHTING

De-l amp

Zoned security lamp circuits

Motion detectors

Install time clocks
ERO Description

Evaluated

$(Y / N)$

Replace existing refrigerator with highefficiency model.

Upgrade fluorescent fixture to highefficiency. T-8 or similar improvements.

Replace, modify or move/renove fixtures to reduce lighting density to level that provides correct illumination.

Upgrade incandescent fixture to permanent compact fluorescent fixture.

Replace fluorescent exit signs with LED technology.

Replace, modify, or move/remove fixtures to reduce lighting to appropriate density.

Install timers to control lighting.

Install occupancy sensors to control lights.

Install daylight sensor to control lights in hall. foyer, or other areas that have windows and low ambient light requirement.

Install EMCS or add field panel and necessary relays to control lights.

Remove or disconnect bulbs or ballasts to reduce lighting density to level of reduced, but satisfactory lllumination.

Rewire building exterior light circuits into zones so that night work lights and security lights are under separate control.

Install motion detectors in series with security light timeclock switch so that selected zones are off except when activated by motion detectors.

Install time clock to turn off/reduce light level at low traffic hours.
N

Units are new

Y

Comment

$Y$

N Local control preferred Hospital security

N Hospital security Zoning preferred 
Table 5.1. (contd)

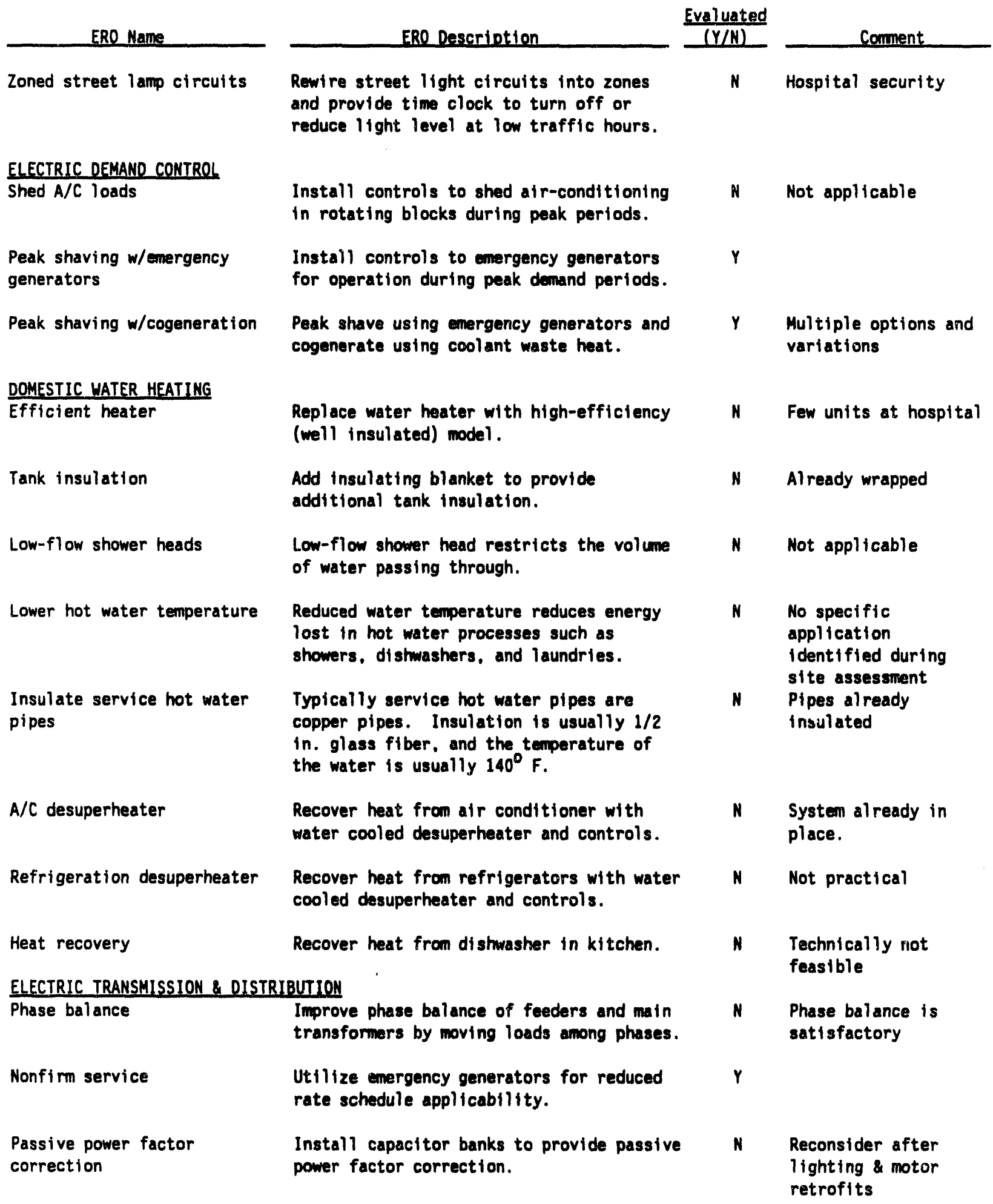


Table 5.1. (contd)

ERO Name

Switched power factor correction

\section{BOILERS}

Preheat combustion air

Feedwater economizer

Air atomizing burner

Boiler tune-up

Flue gas analyzer

Barometric damper

Automatic electric damper

New efficient boiler

Pulse or condensing boiler
ERO Descrintion

Install capacitor banks, power factor transoiucers and automatic switches to provide active power factor correction.

Use gas-to-air heat exchanger or heat pipe to transfer heat of exhaust gasns to the primary contistion air.

Use gas-to-water heat exchanger consisting of feedwater tubes located in the path of the exhaust stream. Economizer can also be employed to heat domestic hot water. space heating water, or process hot water.

Proper atomization of fuel oil is critical to ensure complete combustion with minimum excess air. Air atomizing burners use steam or air for atomization, minimizing excess air and unburnt combustibles, and improving botler efficiency.

A simple tune-up can generally be accomplished within a day, and involves adjusting fuel air ratios at optimal levels at various load conditions.

Flue gas analysis and regular tuning can assist in maintaining optimal boiler efficiency. Gas analysis will monitor oxygen, carbon dioxide, carbon monoxide, and exhaust temperature.

Installing an automatic damper will reduce the standby loss in a boller or furnace. When the burner is off, the damper closes to minimize heat loss through the stack.

Installing an autonatic damper will reduce the standby loss in a boller or furnace. When the burner is off, the damper closes to minimize heat loss through the stack.

When the refurbishment cost of an existing boiler is not economical, boiler replacenent may be considered.

Pulse or condensing boilers have an instantaneous efficiency of more than 90\% and a seasonal efficiency 8 percentage points higher than conventional units.
Evaluated

(Y/N)

Neconsider after lighting \& motor retrofits

N

Not applicable

$N$

Not applicable

Not applicable

Y

N

In place

N

Not applicable

N

Include as standard feature in replacement heaters

N

Boilers are new

N

Boilers are new 
Table 5.1. (contd)

\begin{tabular}{|c|c|c|c|}
\hline ERO Name & ERO Descriotion & $\frac{\text { Evaluated }}{(Y / N)}$ & Comment \\
\hline Fire-tube turbulators & $\begin{array}{l}\text { Turbulators improve overall combustion } \\
\text { efficiency in fire-tube bollers. } \\
\text { Efficiency increases due to better heat } \\
\text { transfer and lower stack temperature. }\end{array}$ & N & Not applicable \\
\hline $\begin{array}{l}\text { Automatic boller-blow-down } \\
\text { system with heat recovery }\end{array}$ & $\begin{array}{l}\text { Controlled boller blow dow: has the } \\
\text { potential to reduce the blow-down losses. } \\
\text { The continuous blow-down system senses the } \\
\text { TOS level and controls blow-down rate. }\end{array}$ & N & $\begin{array}{l}\text { Not applicable, } \\
\text { system al ready } \\
\text { installed }\end{array}$ \\
\hline Oxygen trim control & $\begin{array}{l}\text { Oxygen trim controls assist in maintaining } \\
\text { low excess air levels by continuously } \\
\text { monitoring oxygen in the stack and } \\
\text { adjusting the dampers accordingly. }\end{array}$ & N & $\begin{array}{l}\text { Not appl fcable, } \\
\text { system al ready } \\
\text { installed }\end{array}$ \\
\hline \multicolumn{4}{|c|}{ BOILER AUXILIARIES \& DISTRIBUTION } \\
\hline ASD feedwater pump & $\begin{array}{l}\text { Install adjustable-speed drive to } \\
\text { feedwater punp controlled by steam drum } \\
\text { water level. }\end{array}$ & N & Not appl lcable \\
\hline ASD combustion fan & $\begin{array}{l}\text { Install adjustable-speed drives for } \\
\text { combustion air and stack fans controlled } \\
\text { by firing rate and static pressure. }\end{array}$ & N & Too few units at site \\
\hline \multicolumn{4}{|l|}{ CHILLERS } \\
\hline Chilled water reset & $\begin{array}{l}\text { Add controls to reset chilled water } \\
\text { temperature on chiller load. }\end{array}$ & N & $\begin{array}{l}\text { Light cooling } \\
\text { loads/few units }\end{array}$ \\
\hline Efficient chiller & Replace chiller with high-efficiency unit. & N & $\begin{array}{l}\text { Light cooling } \\
\text { loads/few units }\end{array}$ \\
\hline Insulate ceilings & $\begin{array}{l}\text { Batt type fiberglass insulation and blown- } \\
\text { in fiberglass or cellulose are most } \\
\text { frequently used as celling insulation. }\end{array}$ & N & $\begin{array}{l}\text { Roof al ready } \\
\text { insulated }\end{array}$ \\
\hline Insulate walls & $\begin{array}{l}\text { Insulate with rigid, nonrigid, poured-in } \\
\text { or blow-in insulation. For wood frame } \\
\text { wall or cavity wall renove top strip of } \\
\text { siding or drill holes in sheathing or } \\
\text { inside gyp-board and completely fill each } \\
\text { stud space with blown-in insulation. }\end{array}$ & N & $\begin{array}{l}\text { Walls already } \\
\text { insulated }\end{array}$ \\
\hline $\begin{array}{l}\text { Insulate floor above crawl } \\
\text { space }\end{array}$ & $\begin{array}{l}\text { Fiberglass batt or blanket insulation is } \\
\text { ideally suited for insulating floors above } \\
\text { crawl spaces. Typically, the insulation } \\
\text { is hung using a wire mesh, nails, and } \\
\text { staples. Vapor barrier is installed } \\
\text { against the floor surface prior to } \\
\text { installation of the insulation. }\end{array}$ & N & Not applicable \\
\hline
\end{tabular}


Table 5.1. (contd)

ERO Name

Storm windows/doors and multi-glazed windows

Tinted/reflective window film

Insulate supply and return ducts

Weatherstripping

Caulking

Reduce infiltration through doors

SPACE HEATING

Infrared heaters
ERO Description

Storm windows create a "dead-air" space

for insulation and also reduce

infiltration. Multi-glazed windows

replace existing windows.

Window tinting or micro-louver screens can be applied to an existing window to reduce solar heat gain.

Add insulation to supply and return ducts.

Install weatherstripping to door and window perimeters to provide a tight seal limiting or eliminating infiltration.

Caulk should be applied in building structures where air can infiltrate.

Install air curtain or vestibule at high infiltration entrances.

Provide spot or space heating by overhead infrared heating system to provide comfort Evaluated $(Y / N)$

N with lower air temperature and corresponding lower envelope loss: also reduces energy used to power fans and pumps.
All windows are double-glazed

Not applicable

Not applicable Not applicable

Comment$$
\text { Not applicable }
$$

N Not applicable

$Y$ Not applicabie 


\subsection{Energy Resource Opportunity Evaluations}

A narrative description of each ERO, including information on the initial cost, energy and dollar savings, impacts on operations and maintenance, energy security, and environmental issues, is provided within each ERO analysis section. Brief descriptions of the evaluation methodologies and technical and cost assumptions are also included.

The ERO life-cycle cost analysis for all EROs was completed using either the Lighting Technology Screening Matrix (LTSM) or the Building Life-cycle Cost Program (BLCC). This technical and economic analysis was performed in fiscal year 1992 and uses the 1992 discount factor of 4.6\% for federal projects and the 1992 energy price indices as published by the National Institute of Standards and Technology (NIST 1991) (See Appendix for descriptions of the LTSM and BLCC software). A similar analysis using the 1993 discount rate of $4.0 \%$ would show increases in most present values of between 5\% and 10\%, but would have no effect on energy savings, and probably no effect on the ranking of EROs. Material and labor costs for lighting EROs are taken from the LTSM unless otherwise noted.

At the end of each ERO analysis section, a summary table presents the operational performance of energy end-use equipment before and after the implementation of the ERO. The summary tables also provide the results of the life-cycle cost analysis, including the net present value (NPV) and value index (VI) of each ERO. The "NPV \$" (NPV in 1992 dollars) value in the third section of each analysis results table is the difference in the total life-cycle cost between the existing and retrofit option. All options must show a positive NPV to be considered a viable ERO. The "value index," also in the third section of each analysis results table, is a value used to prioritize resource opportunities in terms of their efficient use of dollar resources (NPV divided by the first cost of the retrofit). Recent 1992 PG\&E rebates generally apply to some of the lighting retrofit or replacement EROs. In these cases, additional NPVs and VIs are calculated that reflect the possible first cost savings associated with the 1992 rebate level. These NPVs and VIs are included solely for reference.

Unless otherwise noted, the energy cost used in this analysis is based on the transmission rate schedule for typical operating time periods. This relates to an average cost of $\$ 0.0509 / \mathrm{kWh}$ derived from the actual consumption and costs shown in Tables 3.4, 3.5, and 3.6. The demand charges were based on an average cost of $\$ 5.10 / \mathrm{kW}$ for the entire year since the summer and winter months are of equal length (six months each). Analysis results and potential savings are presented by fuel type: fuel oil No. 2 (FO2), natural gas (NG), and electricity. Each ERO is evaluated as an independent measure, which allows direct economic comparison of all EROs.

Demand savings are based on assumptions of equipment and lighting operating schedules compared with utility peak and off-peak schedules. Any additional air conditioning (A/C) savings attributable to reduced cooling loads from lighting improvements are estimated based on standard methodologies found in the ASHRAE Handbook HVAC Systems and Applications (ASHRAE 1987) or "The Domino Effect: Lighting/Air Conditioning/Energy/Environment" (Mendelson and Rundquist 
1991). Local factors including climate area, cooling degree days, building characteristics, and loading were used to derive the estimate. A value of $16 \%$ of the kilowatthour (kWh) savings associated with reduced lighting loads is estimated as the additional $A / C$ savings for most of the standard lighting EROs (see each ERO in Section 6.0 for actual values). The demand and A/C savings values are represented in the tables and are used to estimate total savings potential whenever applicable. For consistency between EROs, the life-cycle cost portion of the analysis was conservatively calculated without the added cost and energy savings of demand reduction or $\mathrm{A} / \mathrm{C}$ savings. This practice is considered generally acceptable because the life-cycle cost analysis is primarily used in determining the viability and ranking of resource opportunities; and in most cases, demand and A/C savings are proportional to energy consumption savings. Those cases where they are not necessarily proportional (i.e., peak shaving) will be specifically noted.

\subsection{Lighting and Lighting Control EROs}

Approximately $26 \%$ of the electrical energy supplied to DGMC is used for lighting. Few of the existing ballasts used for fluorescent lighting are as efficient as those that are currently available. Cost-effective lamps and ballasts, installation of timers, occupancy sensors, reduction of light level, and installation of timeclock EROs are evaluated in this section. In many cases, energy can be saved by installing lighting controls and making wiring modifications that result in reduced lighting operation. In only a few cases can the lighting levels be reduced and still maintain federal design levels.

\subsubsection{Data and Assumptions Common to All Lighting EROs}

Data and assumptions that apply to most, or all, of the EROs are presented as follows for convenient reference.

- fixture modification vs fixture replacement - Because the hospital is less than four years old, all of the lighting fixtures are in good condition. Therefore, lighting EROs normally pertain to fixture modification instead of fixture replacement. Conversion from incandescent to fluorescent technology, where fixture replacement was necessary, was the exception.

- fixture type and quantity - The existing fixture inventory was obtained from the hospital equipment inventory listing, equipment drawings, and site plan drawings. Some of the specialty lights were inventoried during the energy walk-through audit. Thus, the numbers representing fixture quantities in each analysis section are not exact, but are believed to reasonably characterize existing lighting at the site.

- existing ballasts - The ballasts used in all existing fluorescent fixtures were assumed to be the energy-efficient $60 \mathrm{hz}$ magnetic "Wattmizer" type.

- light levels - Unless otherwise noted, existing light levels are adequate for visual activities 
conducted in a space as compared with the values presented in the Illuminating Engineering Society of North America Lighting Handbook (IES 1981). The retrofit fixtures will provide the same light level, or just slightly less, in most cases.

- operating hours - The hours of operation for fluorescent light fixtures were averaged at $16 \mathrm{~h} / \mathrm{d}$. Some lighting types were singled out and the hours of operation were estimated based on an energy audit.

- maintenance costs - Maintenance cost savings are expressed as annualized values. Maintenance savings are chiefly because of longer lamp life (i.e., fluorescent lamps have a much longer life than standard incandescent), resulting in lower lamp replacement costs. In cases where the retrofit maintenance cost is only slightly less than the existing maintenance cost, the savings are assumed to be zero. This results in a slightly conservative assessment of NPV and resource potential.

- penetration of EROs - Unless otherwise stated, all feasible retrofits are assumed to be implemented (100\% penetration) in the resource assessments for each ERO.

\subsubsection{Nonenergy Effects Common to All Lighting EROs}

Except in the few cases where additional impacts will be explicitly mentioned, the following statements of maintenance, energy security, and environmental impact apply.

- operation and maintenance - The replacement or retrofit of incandescent to fluorescent fixtures results in reduced maintenance. All other EROs result in post-retrofit maintenance requirements that are identical or nearly identical to the existing maintenance requirements. All nonenergy O\&M costs are reported as annualized values based on all major maintenance costs over the analysis period of 25 years. The operation of lighting systems will not be adversely affected by implementation of any of the EROs.

- energy security - None of the lighting EROs have significant impact on energy security.

- environmental impact - There are no new negative environmental impacts associated with any of the equipment proposed for use in the lighting EROs. The implementation of the lighting EROs will decrease the need for electricity that is produced from sources that have environmental impacts. All lighting EROs will have beneficial environmental effects due to reduced power generation. All ballasts were manufactured after 1979 and, therefore, do not contain polychlorinated biphenyls (PCBs). The issue of lamp disposal may need to be addressed. The replacement of current lamps with high-efficiency models may temporarily increase the quantity of lamp disposal concerned with mercury or other trace elements found in fluorescent lamps. 


\subsubsection{Upgrade Fluorescent Lighting}

\section{Description}

This set of EROs consists of upgrading the existing fluorescent lighting in the hospital to more efficient technologies. In addition to the most efficient primary retrofit option for each fixture type, two other upgrade options were analyzed to take into consideration characteristics of hospital operations that may preclude implementation of maximum energy savings. The three options analyzed for each fixture type are

- Option A - Upgrade all fluorescent lighting to high efficiency T-8 lamps, electronic ballasts, and de-lamping with reflectors where applicable.

- Option B - Upgrade all fluorescent lighting tc slectronic ballasts and de-lamping with reflectors where applicable.

- Option C - Upgrade all fluorescent lighting with electronic ballasts only.

Option A incorporates the highest lighting efficiency with the replacement of the major lighting components. It also involves partial de-lanining and reflector installation in more than $40 \%$ of the fixtures (see Table 6.1 items 2, 3, 4). Of this $4 \overline{0} \overline{7}$, nost fixtures (see Table 6.1 items 2 and 4) may exhibit approximately $14 \%$ light reduction (the remaining $65 \%$ of the fixtures will exhibit light level increases of $4 \%$ to $14 \%$ ). In addition, some reflector products tend to redirect light in a narrower beam that can create lower light levels between fixtures depending on the fixture layout and ceiling height. A pilot installation of several rooms may be useful in determining if this option has any negative aspects.

Option B retains the use of the existing lamps with replacement of the ballasts. This option also involves de-lamping and reflector use in the same $40 \%$ of the fixtures noted in Option A. In this case, light reductions of around $20 \%$ might occur in $<4 \%$ of the fixtures (the remaining $96 \%$ will exhibit virtually undetectable decreases of $2 \%$ or increases of up to $7 \%$ ). As with Option A, a pilot installation is recommended.

Option $C$ also retains the use of existing lamps with replacement of ballasts, but without any delamping or reflector installation. All light levels should show virtually undetectable decreases of $2 \%$ or increases up to $5 \%$.

Some of the two-, three-, and four-lamp fixtures have dimmer control ballasts (ID No. FRA5, FRA7, FRB, FRB5, FRB7, FRC5, and FRC7). These fixtures are always on full power. In converting these ballasts to electronic, the dimmer control should be disconnected. 


\section{Data and Assumptions}

In addition to the general assumptions stated at the beginning of Section 6.1, the following assumptions apply. The only 4-ft long fixtures that use $\mathrm{T}-12,40-\mathrm{W}$ lamps are the ID No. FRB, 2-ft by 4-ft troffer, six-lamp fixtures. One switch controls two lamps while the second controls the remaining four lamps. All remaining 4-ft lamps are the T-12, 34-W type. Additional A/C savings are estimated to be $16 \%$ of the total kilowatthour savings. The existing fixture types and quantities taken from design drawings and walk-through audits are shown in Table 6.1.

Table 6.1 Fluorescent Lighting Fixtures at DGMC

\begin{tabular}{|c|c|c|}
\hline Flxture Iype & $\begin{array}{c}\text { Drawing } \\
\text { Code }\end{array}$ & $\begin{array}{l}\text { Fixture } \\
\text { Count }\end{array}$ \\
\hline One 4-ft lamp. T-12, $34 \mathrm{~W}$ & $\begin{array}{l}\text { FCA } \\
\text { FCB } \\
\text { FRE2 } \\
\text { FRF } \\
\text { FRF3 } \\
\text { FRG } \\
\text { FSB } \\
\text { FSD }\end{array}$ & $\begin{array}{r}1.647 \\
247 \\
19 \\
254 \\
29 \\
667 \\
232 \\
2.313 \\
5.408\end{array}$ \\
\hline Two 4-ft lamps, T-12, $34 \mathrm{~W}$ & $\begin{array}{l}\text { FRC } \\
\text { FRC3 } \\
\text { FRC5* } \\
\text { FRC7* } \\
\text { FRE } \\
\text { FSA } \\
\text { FSC } \\
\text { FSE } \\
\text { FSF }\end{array}$ & $\begin{array}{r}771 \\
396 \\
27 \\
11 \\
781 \\
654 \\
221 \\
221 \\
19 \\
3,081\end{array}$ \\
\hline Three 4-ft lamps, T-12, $34 \mathrm{~W}$ & $\begin{array}{l}\text { FRB } \\
\text { FRB3 } \\
\text { FRB5* } \\
\text { FRB7* }\end{array}$ & $\begin{array}{r}542 \\
41 \\
23 \\
22 \\
600\end{array}$ \\
\hline TOTAL & & 628 \\
\hline $\begin{array}{l}\text { Four 4-ft lamps, T-12, } 34 \\
\text { TOTAL }\end{array}$ & $\begin{array}{l}\text { FRA } \\
\text { FRA3 } \\
\text { FRA5* } \\
\text { FRA7* }\end{array}$ & $\begin{array}{r}221 \\
43 \\
11 \\
46 \\
321\end{array}$ \\
\hline $\begin{array}{l}\text { Six 4-ft lamps, T-12, } 34 \mathrm{~W} \\
\text { TOTAL }\end{array}$ & FRD & $\frac{215}{215}$ \\
\hline
\end{tabular}




\section{Analysis Results}

The quantitative results of this lighting ERO assessment appear in Table 6.2. This table contains specific energy, cost, and economic evaluation information for each fixture group. The "Lumen Ratio" item in the second section of the table is specific to lighting ERO analysis and relates the expected lighting level after retrofit as a percentage of the existing lighting level. A value of 1.00 indicates no expected change in lighting levels after retrofit. A value $<1.00$ indicates an expected percentage reduction in lighting level. A lumen ratio $>1.00$ indicates an expected increase in lighting levels.

Table 6.2. Fluorescent Lighting Upgrade ERO

Existing lighting operating paramaters

\begin{tabular}{|l|l|l|l|l|l|}
\hline \multicolumn{3}{|c|}{ Existing Equipment } & \multicolumn{2}{|c|}{ Annual Energy Consumption } \\
\hline $\begin{array}{l}\text { Item } \\
\text { No. }\end{array}$ & $\begin{array}{l}\text { Fixture Type } \\
\text { (4-ft lamps) }\end{array}$ & $\begin{array}{l}\text { Watts } \\
\text { Each }\end{array}$ & $\begin{array}{l}\text { No. of } \\
\text { Units }\end{array}$ & $\begin{array}{l}\text { Energy } \\
\text { (kWh) }\end{array}$ & $\begin{array}{c}\text { Demand } \\
\text { (kW/month) }\end{array}$ \\
\hline 1 & One lamp T-12, 34-W & 43 & 5408 & 1365033 & 211 \\
2 & Two lamp T-12, 34-W & 72 & 3081 & 1302154 & 222 \\
3 & Three lamp T-12, 34-W & 112 & 628 & 412872 & 70 \\
4 & Four lamp T-12, 34-W & 138 & 321 & 260029 & 46 \\
5 & Six lamp T-12, 40-W & 260 & 215 & 328133 & 53 \\
\hline
\end{tabular}

Efficient lighting operating paramaters

\begin{tabular}{|c|c|c|c|c|c|c|}
\hline \multicolumn{5}{|c|}{ Energy Resource Opportunity } & \multicolumn{2}{|c|}{ Annual Energy Consumption } \\
\hline $\begin{array}{l}\text { Item } \\
\text { No. }\end{array}$ & $\begin{array}{l}\text { New Fixture } \\
\text { (4-ft lamps) }\end{array}$ & $\begin{array}{l}\text { Watts } \\
\text { Each }\end{array}$ & $\begin{array}{l}\text { No. of } \\
\text { Units }\end{array}$ & $\begin{array}{l}\text { Lumen } \\
\text { Ratio }\end{array}$ & $\begin{array}{l}\text { Energy } \\
\text { (kWh) }\end{array}$ & $\begin{array}{l}\text { Demand } \\
\text { (kW/month) }\end{array}$ \\
\hline $\begin{array}{l}1 A \\
1 B \\
1 C\end{array}$ & $\begin{array}{l}\text { One lamp T-8 ELC } \\
\text { One lamp } 34-W \text { ELC } \\
\text { One lamp } 34-W \text { ELC }\end{array}$ & $\begin{array}{l}29 \\
34 \\
34\end{array}$ & $\begin{array}{l}5408 \\
5408 \\
5408\end{array}$ & $\begin{array}{l}1.11 \\
0.96 \\
0.96\end{array}$ & $\begin{array}{r}920604 \\
1079329 \\
1079329\end{array}$ & $\begin{array}{l}157 \\
184 \\
184\end{array}$ \\
\hline $\begin{array}{l}2 A \\
2 B \\
2 C\end{array}$ & $\begin{array}{l}\text { One lamp T-8 ELC REF } \\
\text { One lamp } 34-W \text { ELC REF } \\
\text { Two lamp } 34-W \text { ELC }\end{array}$ & $\begin{array}{l}29 \\
34 \\
63\end{array}$ & $\begin{array}{l}3081 \\
3081 \\
3081\end{array}$ & $\begin{array}{l}0.86 \\
1.01 \\
1.04\end{array}$ & $\begin{array}{r}524479 \\
614906 \\
1139385\end{array}$ & $\begin{array}{r}89 \\
105 \\
194\end{array}$ \\
\hline $\begin{array}{l}3 A \\
3 B \\
3 C\end{array}$ & $\begin{array}{l}\text { Two lamp T-8 ELC REF } \\
\text { Two lamp } 34-W \text { ELC REF } \\
\text { Three lamp } 34-W \text { ELC }\end{array}$ & $\begin{array}{l}65 \\
63 \\
94\end{array}$ & $\begin{array}{l}628 \\
628 \\
628\end{array}$ & $\begin{array}{l}1.14 \\
1.07 \\
1.04\end{array}$ & $\begin{array}{l}239613 \\
232241 \\
346518\end{array}$ & $\begin{array}{l}41 \\
40 \\
59\end{array}$ \\
\hline $\begin{array}{l}4 A \\
48 \\
4 C\end{array}$ & $\begin{array}{l}\text { Two lamp T-8 ELC REF } \\
\text { Two lamp } 34-W \text { ELC REF } \\
\text { Four lamp } 34-W \text { ELC }\end{array}$ & $\begin{array}{r}65 \\
63 \\
122\end{array}$ & $\begin{array}{l}321 \\
321 \\
321\end{array}$ & $\begin{array}{l}0.86 \\
0.80 \\
1.04\end{array}$ & $\begin{array}{l}122478 \\
118709 \\
229881\end{array}$ & $\begin{array}{l}21 \\
20 \\
39\end{array}$ \\
\hline $\begin{array}{l}5 A \\
5 B \\
5 C\end{array}$ & $\begin{array}{l}\text { Six lamp T-8 ELC } \\
\text { Six lamp } 40-W \text { ELC } \\
\text { Six lamp } 40-W \text { ELC }\end{array}$ & $\begin{array}{l}194 \\
220 \\
220\end{array}$ & $\begin{array}{l}215 \\
215 \\
215\end{array}$ & $\begin{array}{l}1.04 \\
1.05 \\
1.05\end{array}$ & $\begin{array}{l}244838 \\
277651 \\
277651\end{array}$ & $\begin{array}{l}42 \\
47 \\
47\end{array}$ \\
\hline
\end{tabular}


Table 6.2. (contd)

Efficient lighting ERO economics

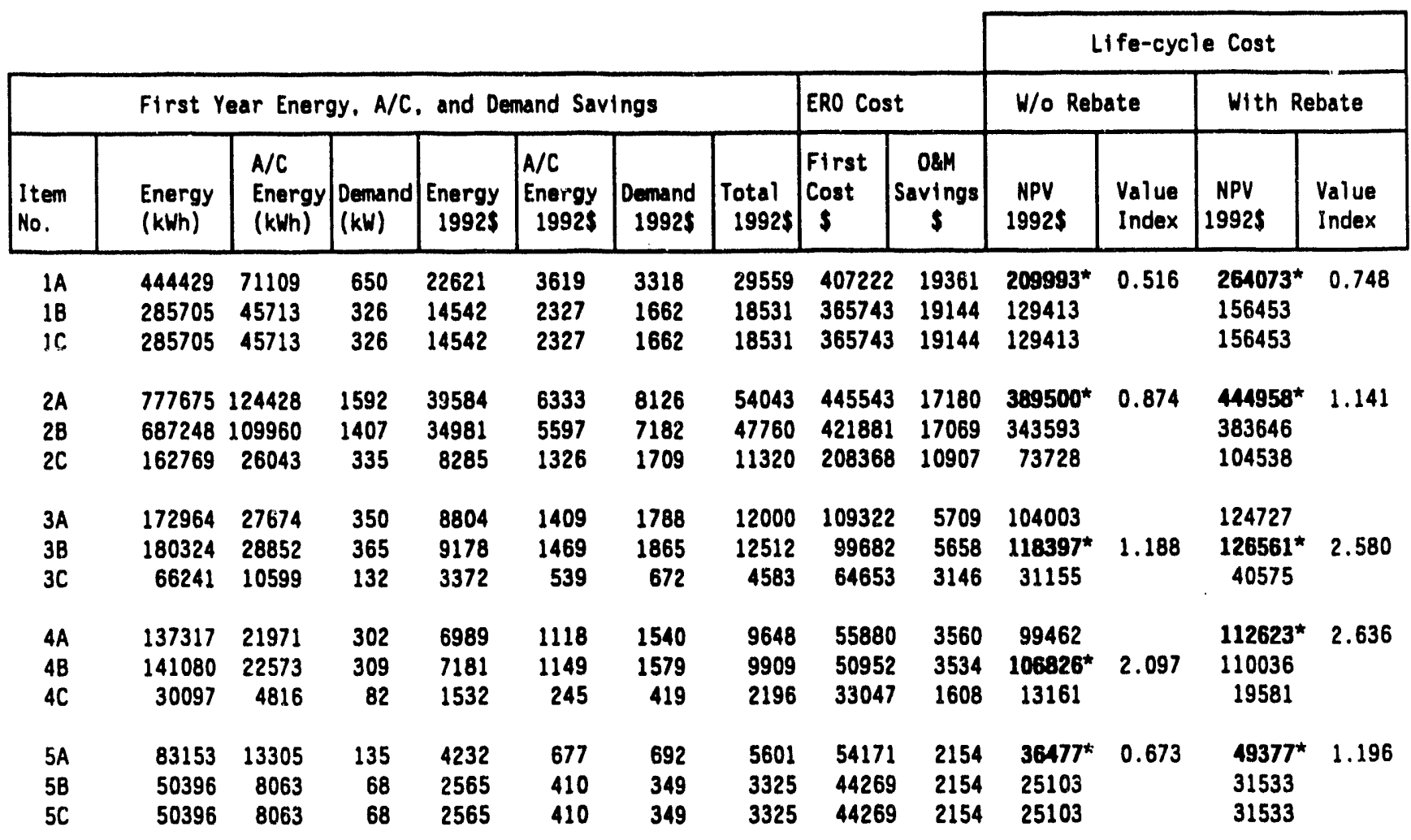

* The NPV values in bold type represent the retrofit options that should be selected based on greatest NPV of all options.

The "New Fixture" descriptions in the second section of Table 6.2 indicate the proposed technology changes. This generally includes replacement of existing ballasts with an electronic version (ELC), the addition of a parabolic reflector (REF), or the conversion to a T-8 lamp and ballast system (T-8). The life-cycle cost information in the third section of the table is shown with and without utility rebate values factored in.

\section{Budget Information}

The total first cost of implementing the maximum NPV options (see Table 6.2 items 1A, 2A, 3B, $4 \mathrm{~B}$, and $5 \mathrm{~A}$ ) without rebates would be $\$ 1,057,572$. This includes material and associated labor costs. If standard rebates (recently offered by the utility) are considered, the first cost of the maximum NPV options (now 1A, 2A, 3B, 4A, and 5A) is estimated to be reduced to $\$ 925,644$. The effect of this reduction is also seen in the increase in the $\mathrm{VI}$ of these options. 


\section{Operation and Maintenance Impacts}

Yearly maintenance cost savings for the maximum NPV options are estimated to be $\$ 47,887$.

\section{Energy, Demand, and Cost Savings}

The first year electric energy savings would be 1,626,661 $\mathrm{kWh}$, for the maximum NPV options, because of the technology change alone. The first year additional electric savings, because of reduced A/C load, would be $260,266 \mathrm{kWh}$. First year electricity demand savings for these same options (excluding possible A/C demand reduction) would be 3,052 kW. The first year total cost savings based on these energy reduction values would be $\$ 111,624$. These savings are based on $100 \%$ implementation of this ERO for a typical operating year.

\section{Recommendations}

Tn receive the maximum benefits detailed above, the options in each category with the highest NPV (see Table 6.2, third section, bold characters) should be implemented. In this case, fixture types 3 and 4 (949 of 9,653 fixtures) would retain the 34-W lamps. One possible advantage of this option would be the eventual use of any remaining stocks of 34- $\mathrm{W}$ lamps. A disadvantage would be the mix of lamp types (T-8, 34-W) that must be stocked and appropriately replaced at burnout for an indefinite period of time. Maintenance personnel would need to be aware and prepared to re-lamp all three- and fc:r-lamp fixtures with 34-W lamps only. Because this dual-lamp-type situation already exists (34-W, 40-W), ii may not be an added burden. The critical data for all three options in each fixture type are represented in the table in case a mix of lamps, use of reflectors, or some other retrofit constraint prohibits the use of only the best option in each fixture type. It is understood that de-lamping with reflector installation has been implemented in selected areas of the hospital with unsuccessful results. With this in mind, it would be important to choose lighting retrofits that retain acceptable light leveis (lumen ratios in Table 6.2 that are near 1.0).

\subsubsection{Upgrade Fluorescent Exit Signs}

\section{Description}

The existing exit light fixtures (ID No. XA) are in excellent condition. They are currently illuminated by T-6, 20-W fluorescent lamps. While these fluorescent lamps are relatively afficient, light emitting diode (LED) fixtures draw less wattage, have a lamp/sign life that exceeds 50 years, and incur virtually no O\&M cost. This ERO proposes the replacement of the existing exit signs with comparable LED signs.

\section{Data and Assumptions}

The inventory of existing fixtures is 74 . Instead of the hours described in the general 
assumptions, exit lights are assumed to be on $24 \mathrm{~h} / \mathrm{d}, 365 \mathrm{~d} / \mathrm{yr}$. Cost estimates are based on vendor quotes and labor estimates from MEANS Electrical Cost Data (R.S. Means Co., Inc. 1991a). A/C savings are estimated to be $16 \%$ of the total kilowatthour savings.

\section{Analysis Results}

The analysis results appear in Table 6.3.

\section{Budget Information}

The total first cost of implementing this ERO is estimated to be $\$ 11,534$. This includes the installation, which requires replacement of the entire fixture.

Table 6.3. Fluorescent Exit Sign Retrofit

Existing lighting operating parameters

\begin{tabular}{|l|l|l|l|l|l|}
\hline \multicolumn{3}{|c|}{ Existing·Equipment } & \multicolumn{2}{|c|}{ Annual Energy Consumption } \\
\hline $\begin{array}{l}\text { Item } \\
\text { No. }\end{array}$ & Fixture Type & $\begin{array}{l}\text { Watts } \\
\text { Each }\end{array}$ & $\begin{array}{l}\text { No. of } \\
\text { Units }\end{array}$ & $\begin{array}{l}\text { Energy } \\
\text { (kWh) }\end{array}$ & $\begin{array}{c}\text { Demand } \\
\text { (kW/month) }\end{array}$ \\
\hline 1 & Exit Sign (Fluor.) & 24 & 74 & 15,558 & 1.7 \\
\hline
\end{tabular}

Efficient lighting operating parameters

\begin{tabular}{|l|l|l|l|l|l|l|}
\hline \multicolumn{2}{|l|}{ Energy Resource Opportunity } & \multicolumn{2}{|l|}{ Annual Energy Consumption } \\
\hline $\begin{array}{l}\text { Item } \\
\text { No. }\end{array}$ & New Fixture & $\begin{array}{l}\text { Watts } \\
\text { Each }\end{array}$ & $\begin{array}{l}\text { No. of } \\
\text { Units }\end{array}$ & $\begin{array}{l}\text { Lumen } \\
\text { Ratio }\end{array}$ & $\begin{array}{l}\text { Energy } \\
\text { (kWh) }\end{array}$ & $\begin{array}{l}\text { Denand } \\
\text { (kW/month) }\end{array}$ \\
\hline 1 & Exit Sign (LED) & 5 & 74 & NA & 3.241 & 0.37 \\
\hline
\end{tabular}

\begin{tabular}{|c|c|c|c|c|c|c|c|c|c|c|c|c|c|}
\hline \multicolumn{10}{|c|}{ Efficient lighting ERO economics } & \multicolumn{4}{|c|}{ Life-cycle Cost } \\
\hline & \multicolumn{7}{|c|}{ First Year Energy, $A / C$, and Demand Savings } & \multicolumn{2}{|c|}{ ERO Cost } & \multicolumn{2}{|c|}{ W/o Rebate } & \multicolumn{2}{|c|}{ With Rebate } \\
\hline $\begin{array}{l}\text { Iten } \\
\text { No. }\end{array}$ & $\begin{array}{l}\text { Energy } \\
(k W h)\end{array}$ & $\begin{array}{l}\text { A/C } \\
\text { Energy } \\
(\mathrm{kWh})\end{array}$ & $\begin{array}{l}\text { Dernand } \\
(\mathrm{kW})\end{array}$ & $\begin{array}{r}\text { Energy } \\
1992 \$\end{array}$ & $\begin{array}{l}\text { A/C } \\
\text { Energy } \\
199 ? S\end{array}$ & $\begin{array}{l}\text { Demand } \\
19925\end{array}$ & $\begin{array}{c}\text { Total } \\
1992 \$\end{array}$ & $\begin{array}{l}\text { First } \\
\text { Cost } \\
\$\end{array}$ & $\begin{array}{c}\text { O\&M } \\
\text { Savings } \\
\$\end{array}$ & $\begin{array}{c}\text { NPV } \\
1992 \$\end{array}$ & $\begin{array}{l}\text { Value } \\
\text { Index }\end{array}$ & $\begin{array}{l}\text { NPV } \\
1992 \$\end{array}$ & $\begin{array}{l}\text { Value } \\
\text { Index }\end{array}$ \\
\hline 1 & 13,613 & 2,178 & 16 & 693 & 111 & 82 & 885 & 11.534 & 217 & 3098 & 0.27 & NA & NA. \\
\hline
\end{tabular}

\section{Operation and Maintenance Impacts}

Maintenance cost savings are estimated at $\$ 217 / \mathrm{yr}$ because of elimination of periodic lamp replacement. 


\section{Energy, Demand, and Cost Savings}

The first year electric energy savings, because of the technology change alone, would be 13,613 $\mathrm{kWh}$. The additional first year electricity savings, because of reduced A/C load, would be 2,178 kWh. First year electricity demand savings for these same options (excluding possible A/C demand reduction) would be $16 \mathrm{~kW}$. The first year total cost savings based on these energy reduction values would be $\$ 885$. These savings are based on $100 \%$ implementation of this ERO for a typical operating year.

\section{Recommendations}

The replacement of current fluorescent exit signs with LED models will reduce energy consumption, as well as maintenance costs, because of the long life of the LED lights. This long life may also reduce the possibility of exit signs remaining unlit if maintenance personnel are unable to replace existing lamps on the routine schedule required by fluorescent technologies. One characteristic of the LED technology that must be considered is the intensity of light produced by the fixture. While LED exit sign technologies appear to meet the requirements of exit sign light levels, some concern has been raised as to their relative effectiveness in heavy smoke conditions. This relative difference in light level between fluorescent and LED technologies should be considered prior to any retrofits.

\subsubsection{Upgrade Incandescent to Compact Fluorescent Lamps}

\section{Description}

This ERO consists of the replacement of limited accessibility interior incandescent lamps with compact fluorescent (CF) lamps. In addition to reduced wattage, the compact fluorescent lamps will last longer, requiring less replacement. The targeted lamps are located in the dining room servery, nurses' stations, and commander's dining room. The lamps currently in use are 150-W incandescent lamps. The replacement compact fluorescents will not provide as much light, but are considered here for wall accent or background lighting where higher exact light levels are not required.

\section{Data and Assumptions}

The inventory of existing lamps is

- servery $=36$

- nurses stations $=24$

- commander's dining room $=9$.

Hours of operation are estimated at $16 \mathrm{~h} / \mathrm{d}$ throughout the year. Cooling savings are estimated to be $16 \%$ of the lighting efficiency savings. 


\section{Analysis Results}

The analysis results appear in Table 6.4 .

\section{Budget Information}

The total first cost of implementing this ERO without rebate would be $\$ 2,051$. With the standard utility rebate included, the first cost would be reduced to only $\$ 1,016$.

\section{Operation and Maintenance Impacts}

Maintenance cost saving is estimated at $\$ 1,114 / \mathrm{yr}$ based on reduced need for lamp replacement.

Table 6.4. Incandescent to Compact Fluorescent Retrofit

Existing lighting operating parameters

\begin{tabular}{|l|l|l|l|l|l|}
\hline \multicolumn{3}{|c|}{ Existing Equipment } & \multicolumn{2}{|c|}{ Annual Energy Consumption } \\
\hline $\begin{array}{l}\text { Item } \\
\text { No. }\end{array}$ & Fixture Type & $\begin{array}{l}\text { Watts } \\
\text { Each }\end{array}$ & $\begin{array}{l}\text { No. of } \\
\text { Units }\end{array}$ & $\begin{array}{l}\text { Energy } \\
(\mathrm{kWh})\end{array}$ & $\begin{array}{c}\text { Demand } \\
\text { (kW/month) }\end{array}$ \\
\hline
\end{tabular}

1 Ceiling 150-W Incan. $150 \quad 69 \quad 60.444 \quad 10.3$

Efficient lighting operating parameters

\begin{tabular}{|l|l|l|l|l|l|l|}
\hline \multicolumn{2}{|l|}{ Energy Resource Opportunity } & \multicolumn{2}{l|}{ Annual Energy Consumption } \\
\hline \begin{tabular}{l|llll} 
Item \\
No.
\end{tabular} & New Fixture & $\begin{array}{l}\text { Watts } \\
\text { Each }\end{array}$ & $\begin{array}{l}\text { No. of } \\
\text { Units }\end{array}$ & $\begin{array}{l}\text { Lumen } \\
\text { Ratio }\end{array}$ & $\begin{array}{l}\text { Energy } \\
(\mathrm{kWh})\end{array}$ & $\begin{array}{l}\text { Demand } \\
\text { (kW/month) }\end{array}$ \\
\hline 1 & Compact Fluorescent & 27 & 69 & NA & 10,880 & 1.8 \\
\hline
\end{tabular}

\begin{tabular}{|c|c|c|c|c|c|c|c|c|c|c|c|c|c|}
\hline \multicolumn{10}{|c|}{ Efficient lighting ERO economics } & \multicolumn{4}{|c|}{ Life-cycle Cost } \\
\hline \multicolumn{8}{|c|}{ First Year Energy, $A / C$, and Demand Savings } & \multicolumn{2}{|c|}{ ERO Cost } & \multicolumn{2}{|c|}{ W/o Rebate } & \multicolumn{2}{|c|}{ With Rebate } \\
\hline $\begin{array}{l}\text { Item } \\
\text { No. }\end{array}$ & $\begin{array}{l}\text { Energy } \\
\text { (kWh) }\end{array}$ & $\begin{array}{l}A / C \\
\text { Energy } \\
(k W h)\end{array}$ & $\begin{array}{l}\text { Demand } \\
(\mathrm{kW})\end{array}$ & $\begin{array}{r}\text { Energy } \\
1992 \$\end{array}$ & $\begin{array}{l}\text { A/C } \\
\text { Energy } \\
19925\end{array}$ & $\begin{array}{l}\text { Demand } \\
1992 \$\end{array}$ & $\begin{array}{c}\text { Total } \\
1992 \$\end{array}$ & $\begin{array}{l}\text { First } \\
\text { Cost } \\
5\end{array}$ & $\begin{array}{c}\text { O\&M } \\
\text { Savings } \\
\$\end{array}$ & $\begin{array}{l}\text { NPV } \\
1992 \$\end{array}$ & $\begin{array}{l}\text { Value } \\
\text { Index }\end{array}$ & $\begin{array}{l}\text { NPV } \\
1992 \$\end{array}$ & $\begin{array}{l}\text { Value } \\
\text { Index }\end{array}$ \\
\hline 1 & 49,564 & 7,930 & 102 & 2,523 & 404 & 520 & 3,447 & 2.051 & 1,114 & 51,609 & 25.2 & 51,885 & 25.3 \\
\hline
\end{tabular}

\section{Energy, Demand, and Cost Savings}

Electric energy savings is estimated at $49,564 \mathrm{kWh} / \mathrm{yr}$ with $\mathrm{A} / \mathrm{C}$ savings of $7,930 \mathrm{kWh} / \mathrm{yr}$ and 
demand savings (with no possible A/C demand savings) of $102 \mathrm{~kW} / \mathrm{yr}$. Total cost savings is estimated at $\$ 3,447 / \mathrm{yr}$.

\section{Recommendations}

The replacement of the $150-\mathrm{W}$ incandescent lights in these areas affects a small number of fixtures, but eliminates some of the least efficient lighting in the medical center. Since the use of the light in each of the three areas varies in function (wall wash, general, food highlighting), consideration should be given to the ultimate applicability of the fluorescent technology prior to retrofit. In addition, the reduction in light output of the replacement lamps must be considered and may not be applicable in all areas. Apparently this type of retrofit was tried in certain nurses' stations and found unacceptable by hospital staff.

\subsubsection{Reduce Lighting Density}

\section{Description}

This ERO consists of reducing the wattage of interior metal halide (MH) lamps found in both the north and south corridors. The current lamps are 400-W (465 fixture watts). Current lighting levels are above that normally needed for corridor areas. In addition, the ceilings above these fixtures are relatively dark, causing inefficient use of the current lighting. The reduction of lamp wattage, along with painting the ceiling area with a light reflective color, is expected to provide adequate corridor lighting with energy savings. As with all lighting reduction EROs, a small test may be useful to determine the practicality and performance of this option.

\section{Data and Assumptions}

The seven fixtures under consideration in this ERO are estimated to have 24-h/d operation throughout the year. Cost estimates are based on MEANS Electrical Cost Data and Repair and Remodeling Cost Data (R.S. Means Co., Inc. 1991a, 1991c).

\begin{tabular}{lccc} 
& Material $(\$)$ & Labor $(\$)$ & Total (\$) \\
\cline { 2 - 4 } & 312 & 70 & 382 \\
Paint ceiling & 15 & 41 & $\frac{56}{438}$ \\
$\quad$ Total $=$ & & &
\end{tabular}

A/C savings are estimated to be $16 \%$ of the kilowatthour savings.

\section{Analysis Results}

The analysis results of this ERO appear in Table 6.5. 
Table 6.5. Reduce Lighting Density

Existing lighting operating parameters

\begin{tabular}{|l|l|l|l|l|c|}
\hline \multicolumn{3}{|c|}{ Existing Equipment } & \multicolumn{2}{|c|}{ Annual Energy Consumption } \\
\hline $\begin{array}{l}\text { Item } \\
\text { No. }\end{array}$ & Fixture Type & $\begin{array}{l}\text { Watts } \\
\text { Each }\end{array}$ & $\begin{array}{l}\text { No. of } \\
\text { Units }\end{array}$ & $\begin{array}{l}\text { Energy } \\
(\mathrm{kWh})\end{array}$ & $\begin{array}{c}\text { Demand } \\
(\mathrm{kW} / \text { month })\end{array}$ \\
\hline 1 & Metal Halide (400-W) & 465 & 7 & 28.514 & 3.3 \\
\hline
\end{tabular}

Efficient lighting operating parameters

\begin{tabular}{|l|l|l|l|l|l|l|}
\hline \multicolumn{2}{|l|}{ Energy Resource Opportunity } & \multicolumn{2}{|l|}{ Annual Energy Consumption } \\
\hline $\begin{array}{l}\text { Item } \\
\text { No. }\end{array}$ & New Fixture & $\begin{array}{l}\text { Watts } \\
\text { Each }\end{array}$ & $\begin{array}{l}\text { No. of } \\
\text { Units }\end{array}$ & $\begin{array}{l}\text { Lumen } \\
\text { Ratio }\end{array}$ & $\begin{array}{l}\text { Energy } \\
(\mathrm{kWh})\end{array}$ & $\begin{array}{l}\text { Denand } \\
(\mathrm{kW} / \mathrm{month})\end{array}$ \\
\hline 1 & Metal Halide (175-W) & 210 & 7 & $\star \star 0.36$ & 12.877 & 1.5 \\
\hline
\end{tabular}

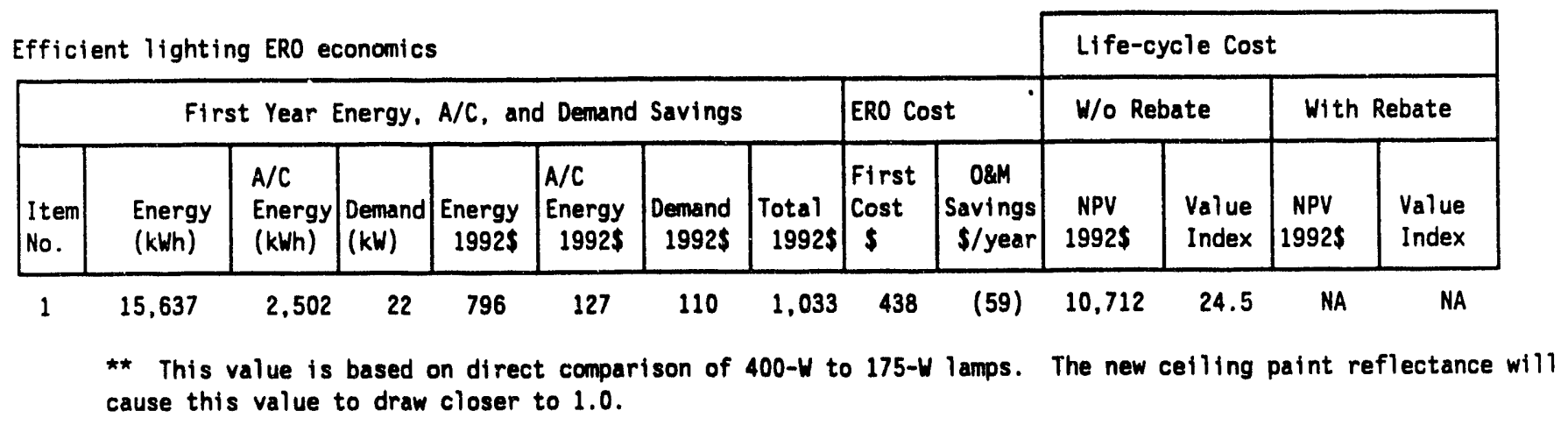

\section{Budget Information}

The total first cost of implementing this ERO would be \$438. This includes the cost of material and labor to install the 175-W MH lamp and painting the ceiling directly above these fixtures.

\section{Operation and Maintenance Impacts}

Maintenance costs are expected to rise by $\$ 59 / y r$ because of decreased lamp life and, therefore, increase replacement of the lower wattage lamps.

\section{Energy, Demand, and Cost Savings}

The electric energy savings is estimated to be $15,637 \mathrm{kWh} / \mathrm{yr}$ with $\mathrm{A} / \mathrm{C}$ savings of $2,502 \mathrm{kWh}$ and demand savings (not including possible A/C demand savings) of $22 \mathrm{~kW} / \mathrm{yr}$. The total energy cost saving is estimated at $\$ 1,033 / y r$. 


\section{Recommendations}

While the proposed replacement of lighting may decrease lighting levels, the results are expected to be adequate for hallway/lobby use. The savings available with this option would be substantial enough to consider the adequacy of lighting levels provided by the reduced-wattage lamps.

\subsubsection{Install Timers for Lighting}

\section{Description}

This ERO consists of installing timers on all walk-in refrigerator and freezer lights located in the hospital kitchen. Occupancy sensors were deleted from consideration because of the low temperature environment. Timers selected must have the warning flicker feature to warn occupants and allow ample time to manually turn the switch on again if it is necessary to reset the timer. No change in the $90-\mathrm{W}$ incandescent lamps is envisioned.

\section{Data and Assumptions}

The inventory of existing lamps is 25 . One refrigerator has four lamps and the remaining units have three lamps each. The hours of operation are estimated at $24 \mathrm{~h} / \mathrm{d}$ throughout the year based on observed practice. Energy savings because of reduced refrigeration/freezer operation are estimated to be equal to $100 \%$ of the energy savings. Cost estimates are based on vendor quotes and MEANS Electrical Cost Data (R.S. Means Co., Inc. 1991a), as follows:

\section{Material (\$) Labor (\$) Total (\$)}

Install timers for lighting control
352
632

\section{Results}

The analysis results appear in Table 6.6.

\section{Budget Information}

The total first cost of implementing this ERO would be $\$ 632$. This includes the cost of material and labor to install the timers. With the standard utility rebate included, the first costs of installation would be reduced to $\$ 382$.

Operation and Maintenance Impacts

Maintenance cost savings are estimated at $\$ 558 / \mathbf{y r}$. 
Table 6.6. Reduce Refrigeration Lighting with Timers

Existing lighting operating parameters

\begin{tabular}{|l|l|l|l|l|l|}
\hline \multicolumn{3}{|c|}{ Existing Equipment } & \multicolumn{2}{|c|}{ Annual Energy Consumption } \\
\hline $\begin{array}{l}\text { Item } \\
\text { No. }\end{array}$ & Fixture Type & $\begin{array}{l}\text { Watts } \\
\text { Each }\end{array}$ & $\begin{array}{l}\text { No. of } \\
\text { Units }\end{array}$ & $\begin{array}{l}\text { Energy } \\
(\mathrm{kWh})\end{array}$ & $\begin{array}{c}\text { Denand } \\
\text { (kW/month) }\end{array}$ \\
\hline 1 & Incandescent $(90-W)$ & 90 & 25 & 19.710 & 2.2 \\
\hline
\end{tabular}

Efficient lighting operating parameters

\begin{tabular}{|l|l|l|l|l|l|l|}
\hline \multicolumn{2}{|l|}{ Energy Resource Opportunity } & \multicolumn{2}{|l|}{ Annual Energy Consumption } \\
\hline $\begin{array}{l}\text { Item } \\
\text { No. }\end{array}$ & New Fixture & $\begin{array}{l}\text { Watts } \\
\text { Each }\end{array}$ & $\begin{array}{l}\text { No. of } \\
\text { Units }\end{array}$ & $\begin{array}{l}\text { Lumen } \\
\text { Ratio }\end{array}$ & $\begin{array}{l}\text { Energy } \\
\text { (kWh) }\end{array}$ & $\begin{array}{l}\text { Demand } \\
\text { (kW/month) }\end{array}$ \\
\hline 1 & Inc. (90-W) w/Timer & 90 & 25 & 1.00 & 821 & 2.2 \\
\hline
\end{tabular}

\begin{tabular}{|c|c|c|c|c|c|c|c|c|c|c|c|c|c|}
\hline \multicolumn{10}{|c|}{ Efficient lighting ERO economics } & \multicolumn{4}{|c|}{ Life-cycle Cost } \\
\hline \multicolumn{8}{|c|}{ First Year Energy, Refrigeration, and Demand Savings } & \multicolumn{2}{|c|}{ ERO Cost } & \multicolumn{2}{|c|}{ W/o Rebate } & \multicolumn{2}{|c|}{ With Rebate } \\
\hline $\begin{array}{l}\text { Item } \\
\text { No. }\end{array}$ & $\begin{array}{l}\text { Energy } \\
\text { (kWh) }\end{array}$ & $\begin{array}{l}\text { Refr. } \\
\text { Energy } \\
\text { (kWh) }\end{array}$ & $\begin{array}{l}\text { Demand } \\
(\mathrm{kW})\end{array}$ & \begin{tabular}{|} 
Energy \\
$1992 \$$
\end{tabular} & $\begin{array}{l}\text { Refr. } \\
\text { Energy } \\
1992 \$\end{array}$ & $\begin{array}{l}\text { Demand } \\
1992 \$\end{array}$ & $\begin{array}{c}\text { Total } \\
1992 \$\end{array}$ & $\begin{array}{l}\text { First } \\
\text { Cost } \\
5\end{array}$ & $\begin{array}{c}\text { O\&M } \\
\text { Savings } \\
\text { S/year }\end{array}$ & $\begin{array}{c}\text { NPV } \\
1992 \$\end{array}$ & $\begin{array}{l}\text { Value } \\
\text { Index }\end{array}$ & $\begin{array}{c}\text { NPY } \\
1992 \$\end{array}$ & $\begin{array}{l}\text { Value } \\
\text { Index }\end{array}$ \\
\hline 1 & 18,889 & 18,889 & 0 & 961 & 961 & 0 & 1,923 & 632 & 558 & 27.400 & 43.4 & 27,650 & 37.7 \\
\hline
\end{tabular}

\section{Energy, Demand, and Cost Savings}

The electric energy savings is estimated to be $18,889 \mathrm{kWh} / \mathrm{yr}$ with reduced refrigeration load savings at an additional $18,889 \mathrm{kWh} / \mathrm{yr}$. Demand savings cannot be considered applicable because the exact time of use of the lighting is not on a set schedule. The total first year cost saving is estimated at $\$ 1,923 / \mathrm{yr}$.

\section{Recommendations}

Other methods of achieving this savings, such as improved diligence by staff in turning off lights, were not considered as permanent or effective as the installation of timers. This same timer system may also be applicable in other storage or low/ use areas.

\subsubsection{Install Daylight Lighting Control}

\section{Description}

This ERO consists of installing electronic lighting controls to lights located in curridors with 
windows that provide sufficient lighting during the daylight hours, eliminating hallway lighting during daylight hours. The electronic lighting control is similar in function to a photocell control, but considered more reliable. It is also programmable with an on-off adjustment for program flexibility.

\section{Data and Assumptions}

The applicable lighting fixtures are as follows:

- North corridor - two 175-W metal halide (MH) fixtures per floor (four floors) in hall by windows. The two 175-W MH fixtures by the elevator are omitted for all four floors.

- South corridor - two 175-W MH fixtures per floor (three floors) by the windows of elevators.

- North corridor fluorescent light fixtures

- 1st floor, 9 ea

- 2nd floor, $17 \mathrm{ea}$

- 3rd floor, 16 ea

- 4th floor, 17 ea

- East corridor fluorescent light fixtures

- 1st floor, 9 ea.

These lights are on $24 \mathrm{~h} / \mathrm{d}$ throughout the year. With the completion of this ERO, the hours of operation will be 4,307 nondaylight hours. Data were obtained from the Cimactic Atlas of the United States (U.S. Department of Commerce 1977) for 38-1/4 north latitude. Cost estimates are based on vendor quotes and labor estimates and MEANS Electrical Cost Data (R.S. Means Co., Inc. 1991a) as follows:

Install electronic lighting control

Material (\$) Labor $(\boldsymbol{S})$ Total (\$)

1. North corridor, $8 \mathrm{MH}$ fixtures

2. South corridor, $6 \mathrm{MH}$ fixtures

1,148

560

1,708

3. North corridor, 59 fluorescent fixtures

861

420

1,281

4. East corridor, 9 fluorescent fixtures

1,148

2,065

3,213

Total

287

315

$-602$

6,804

A/C savings from reduced lighting are estimated to be $16 \%$ of the energy saved by the retrofit.

Analysis Results

The analysis results appear in Table 6.7. 
Table 6.7. Corridor Daylighting Control

Existing lighting operating parameters

\begin{tabular}{|l|l|l|l|l|l|}
\hline \multicolumn{3}{|l|}{ Existing Equipinent } & \multicolumn{2}{|c|}{ Annual Energy Consumption } \\
\hline $\begin{array}{l}\text { Item } \\
\text { No. }\end{array}$ & Fixture Type & $\begin{array}{l}\text { Watts } \\
\text { Each }\end{array}$ & $\begin{array}{l}\text { No. of } \\
\text { Units }\end{array}$ & $\begin{array}{l}\text { Energy } \\
\text { (kWh) }\end{array}$ & $\begin{array}{c}\text { Demand } \\
\text { (kW/month) }\end{array}$ \\
\hline 1 & MH (175-W) & 210 & 14 & 25.754 & 2.9 \\
2 & Fluorescent & 68 & 68 & 40,506 & 4.6 \\
\hline
\end{tabular}

Efficient lighting operating parameters

\begin{tabular}{|l|l|l|l|l|l|l|}
\hline \multicolumn{2}{|l|}{ Energy Resource Opportunity } & \multicolumn{2}{|l|}{ Annual Energy Consumption } \\
\hline $\begin{array}{l}\text { Item } \\
\text { No. }\end{array}$ & New Fixture & $\begin{array}{l}\text { Watts } \\
\text { Each }\end{array}$ & $\begin{array}{l}\text { No. of } \\
\text { Units }\end{array}$ & $\begin{array}{l}\text { Lumen } \\
\text { Ratio }\end{array}$ & $\begin{array}{l}\text { Energy } \\
(\mathrm{kWh})\end{array}$ & $\begin{array}{l}\text { Demand } \\
\text { (kW/month) }\end{array}$ \\
\hline 1 & MH (175-6) w/Control & 210 & 14 & 1.00 & 12.663 & 0 \\
2 & Fluorescent w/Control & 68 & 68 & 1.00 & 19.916 & 0 \\
\hline
\end{tabular}

Efficient lighting ERO economics

\begin{tabular}{|c|c|c|c|c|c|c|c|c|c|c|c|c|c|}
\hline \multicolumn{8}{|c|}{ First Year Energy, A/C, and Demand Savings } & \multicolumn{2}{|c|}{ ERO Cost } & \multicolumn{2}{|c|}{ W/o Rebate } & \multicolumn{2}{|c|}{ With Rebate } \\
\hline $\begin{array}{l}\text { Item } \\
\text { No. }\end{array}$ & $\begin{array}{l}\text { Energy } \\
\text { (kWh) }\end{array}$ & $\begin{array}{l}A / C \\
\text { Energy } \\
\text { (kWh) }\end{array}$ & $\begin{array}{l}\text { Demand } \\
(\mathrm{kW})\end{array}$ & \begin{tabular}{|} 
Energy \\
$1992 \$$
\end{tabular} & $\begin{array}{l}A / C \\
\text { Energy } \\
1992 \$\end{array}$ & $\begin{array}{r}\text { Demand } \\
1992 \$\end{array}$ & \begin{tabular}{|c|} 
Total \\
$1992 \$$
\end{tabular} & $\begin{array}{l}\text { First } \\
\text { Cost } \\
5\end{array}$ & $\begin{array}{l}\text { O\&M } \\
\text { Savings } \\
\text { \$/year }\end{array}$ & $\begin{array}{l}\text { NPV } \\
1992 S\end{array}$ & $\begin{array}{l}\text { Value } \\
\text { Index }\end{array}$ & $\begin{array}{c}\text { NPV } \\
1992 \$\end{array}$ & $\begin{array}{l}\text { Value } \\
\text { Index }\end{array}$ \\
\hline $\begin{array}{l}1 \\
2\end{array}$ & $\begin{array}{l}13,091 \\
20,590\end{array}$ & $\begin{array}{l}2.095 \\
3.294\end{array}$ & $\begin{array}{l}35 \\
55\end{array}$ & $\begin{array}{r}666 \\
1,048\end{array}$ & $\begin{array}{l}107 \\
168\end{array}$ & $\begin{array}{l}177 \\
281\end{array}$ & $\begin{array}{r}950 \\
1.497\end{array}$ & $\begin{array}{l}6.804 \\
3.815\end{array}$ & $\begin{array}{l}123 \\
100\end{array}$ & $\begin{array}{l}11,389 \\
16,447\end{array}$ & $\begin{array}{l}1.7 \\
4.3\end{array}$ & $\begin{array}{l}\text { NA } \\
\text { NA }\end{array}$ & $\begin{array}{l}\text { NA } \\
\text { NA }\end{array}$ \\
\hline
\end{tabular}

\section{Budget Information}

The total first cost of implementing this ERO would be $\$ 10,619$. This includes the cost of material and labor to install the electronic controls for both the MH and fluorescent fixtures.

\section{Operation and Maintenance Impacts}

Maintenance cost saving is estimated at $\$ 223 / \mathrm{yr}$ because of reduced need for lamp replacement.

\section{Energy, Demand, and Cost Savings}

The electric energy savings is estimated to be 33,681 $\mathrm{kWh} / \mathrm{yr}$ with A/C savings of 5,389 $\mathrm{kWh} / \mathrm{yr}$. Demand savings are estimated at $90 \mathrm{~kW}$ with no demand credit taken for $\mathrm{A} / \mathrm{C}$ reduction. The total first year energy cost saving would be $\$ 1,714 / \mathrm{yr}$. 


\section{Recommendations}

This ERO makes optimal use of "free" lighting and may apply to other hospital areas. Care should be taken in the programming of the controls for the MH fixtures. Because continuous on and off operation can erode the life of these lamps more than others, care should be taken to reduce these effects with longer lead times between switching. The hospital should also consider replacing failed exterior light photocells with electronic lighting controls proposed here on a replacement-on-failure basis. The reliability of the electronic control is considered better than photocells.

\subsection{Fan and Pump Motor EROs}

The rooftop unit (RTU) fans and drive motors for the air handler units (AHUs) are all energy efficient. At the present time, these units are operated $24 \mathrm{~h} / \mathrm{d}$ throughout the year. Installing adjustable frequency drive controls for both the supply and exhaust fan motors, for those AHUs that only need to be operated from 7:00 a.m. to 6:00 p.m. or 7:00 a.m. to 11:00 p.m., will result in substantial electric energy savings.

Pumps located at the Energy Plant are driven by standard efficiency electric motors. The units that operate at least half-time and are 2 hp or larger were analyzed for replacement with energyefficient (EE) motors. Downsizing of electric motors was also considered for some of the applications.

\subsubsection{Install Adjustable Speed Drives for Ventilation Fans}

\section{Description}

This ERO consists of installing adjustable speed drive (ASD) controls to selected AHU supply and exhaust fans. The drive motors selected are ones that need to be operated at full capacity from 7:00 a.m. to 6:00 p.m. or from 7:00 a.m. to 11:00 p.m. only and are 2 hp or larger. Optimum start/stop was tried, but was not acceptable to occupants because of the resulting poor air circulation, temperature, humidity, and indoor air quality. Use of ASDs will permit fan operation during the "off hours" at 25\% speed (25\% volume flow). These units would be controlled through the existing energy management system currently used by the hospital (see Section 7.2 for more details).

\section{Data and Assumptions}

The AHUs considered for ASD installation are listed in Table 6.8. The energy cost used is based on the transmission rate schedule at an average cost of $\$ 0.046 / \mathrm{kWh}$. This rate was based on an energy consumption split between the partial-peak and off-peak rates of $27 \%$ and $73 \%$, respectively. The summer and winter rates were averaged (six months each) prior to prorating the rates to the above percentages. No demand savings was used because operation of the ASDs occurs during nonpeak hours. All fans are operated from 7:00 a.m. to 6:00 p.m., except No. E27, which operates 
until 11:00 p.m. Cost estimates are based on vendor quotes and labor estimates from MEANS Electrical Cost Data (R.S. Means Co., Inc. 1991a).

Table 6.8 Roof Top AHU Characteristics

$\begin{array}{cccc}\text { Item } & \text { L. } D . \text { No, } & \text { Supply hp } & \text { Exhaust hp } \\ 1 & \text { A18 } & 15 & 3 \\ 2 & A 37 & 15 & 2 \\ 3 & \text { B23/46 } & 20 & 5 \\ 4 & B 45 & 15 & 2 \\ 5 & \text { C21 } & 25 & 7.5 \\ 6 & \text { C28 } & 25 & 5 \\ 7 & \text { C34 } & 25 & 5 \\ 8 & \text { C43 } & 25 & 5 \\ 9 & \text { D40 } & 30 & 7.5 \\ 10 & \text { D42 } & 40 & 7.5 \\ 11 & \text { D44 } & 40 & 7.5 \\ 12 & \text { E15 } & 40 & 10 \\ 13 & \text { E16 } & 40 & 10 \\ 14 & \text { E27 } & 40 & 10 \\ 15 & \text { F22 } & 60 & 15 \\ 16 & \text { F41 } & 50 & 15\end{array}$

\section{Analysis Results}

Results for the supply fans appear in Table 6.9 and in Table 6.10 for the exhaust fans. Because the DGMC motors are relatively new and energy efficient, no current utility rebates apply.

\section{Budget Information}

The total first cost of this ERO for all supply and exhaust fan motors would be $\$ 283,371$.

\section{Operation and Maintenance Impacts}

No appreciable operation or maintenance impacts are expected.

\section{Energy, Demand, and Cost Savings}

The electric energy savings is estimated to be $2,272,564 \mathrm{kWh} / \mathrm{yr}$. No demand saving would be realized from this ERO because savings occur on'y during nonpeak hours. The total energy cost saving would be $\$ 104,608$. 
Table 6.9. Adjustable Speed Drive Supply Fan Motors

Existing supply fan motor operating paramaters

\begin{tabular}{|c|c|c|c|c|}
\hline \multicolumn{3}{|c|}{ Existing Equipment } & \multicolumn{2}{|c|}{ Annual Energy Consumption } \\
\hline $\begin{array}{l}\text { Item } \\
\text { No. }\end{array}$ & Supply Fan Size & $\begin{array}{l}\text { No. of } \\
\text { Units }\end{array}$ & $\begin{array}{l}\text { Energy } \\
(\mathrm{kWh})\end{array}$ & $\begin{array}{l}\text { Demand } \\
\text { (kW/month) }\end{array}$ \\
\hline $\begin{array}{l}1 \\
2 \\
3 \\
4 \\
5 \\
6 \\
7 \\
8\end{array}$ & $\begin{array}{l}15 \mathrm{hp} \text { Fan } \\
20 \mathrm{hp} \text { Fan } \\
25 \mathrm{hp} \text { Fan } \\
30 \mathrm{hp} \text { Fan } \\
40 \mathrm{hp} \text { Fan } \\
50 \mathrm{hp} \text { Fan } \\
60 \mathrm{hp} \text { Fan } \\
40 \mathrm{hp} \text { Fan }\end{array}$ & $\begin{array}{l}3 \\
1 \\
4 \\
1 \\
4 \\
1 \\
1 \\
1\end{array}$ & $\begin{array}{r}323,157 \\
143,626 \\
718,128 \\
215,438 \\
1,140,232 \\
356,3 \varepsilon 3 \\
418,908 \\
285,058\end{array}$ & $\begin{array}{l}0 \\
0 \\
0 \\
0 \\
0 \\
0 \\
0 \\
0\end{array}$ \\
\hline
\end{tabular}

Efficient supply fan motor operating parameters

\begin{tabular}{|c|c|c|c|c|}
\hline \multicolumn{3}{|c|}{ Energy Resource Opportunity } & \multicolumn{2}{|c|}{ Annual Energy Consumption } \\
\hline $\begin{array}{l}\text { Item } \\
\text { No. }\end{array}$ & $\begin{array}{l}\text { Supply Fan S1ze } \\
\text { (w/Control) }\end{array}$ & $\begin{array}{l}\text { No. of } \\
\text { Units }\end{array}$ & $\begin{array}{l}\text { Energy } \\
\text { (kWh) }\end{array}$ & $\begin{array}{l}\text { Demand } \\
\text { (kW/month) }\end{array}$ \\
\hline $\begin{array}{l}1 \\
2 \\
3 \\
4 \\
5 \\
6 \\
7 \\
8\end{array}$ & $\begin{array}{l}15 \mathrm{hp} \text { Fan } \\
20 \mathrm{hp} \text { Fan } \\
25 \mathrm{hp} \text { Fan } \\
30 \mathrm{hp} \text { Fan } \\
40 \mathrm{hp} \text { Fan } \\
50 \mathrm{hp} \text { Fan } \\
60 \mathrm{hp} \text { Fan } \\
40 \mathrm{hp} \text { Fan }\end{array}$ & $\begin{array}{l}3 \\
1 \\
4 \\
1 \\
4 \\
1 \\
1 \\
1\end{array}$ & $\begin{array}{r}153,573 \\
68,255 \\
341,272 \\
102,382 \\
541,872 \\
169,335 \\
199,076 \\
193,008\end{array}$ & $\begin{array}{l}0 \\
0 \\
0 \\
0 \\
0 \\
0 \\
0 \\
0\end{array}$ \\
\hline
\end{tabular}

\begin{tabular}{|c|c|c|c|c|c|c|c|c|c|c|c|}
\hline \multicolumn{8}{|c|}{ Efficient supply fan motor ERO economics } & \multicolumn{4}{|c|}{ Life-cycle Cost } \\
\hline \multicolumn{6}{|c|}{ First Year Energy, and Demand Savings } & \multicolumn{2}{|c|}{ ERO Cost } & \multicolumn{2}{|c|}{ W/o Rebate } & \multicolumn{2}{|c|}{ With Rebate } \\
\hline $\begin{array}{l}\text { Item } \\
\text { No. }\end{array}$ & $\begin{array}{l}\text { Energy } \\
\text { (kWh) }\end{array}$ & $\begin{array}{l}\text { Demand } \\
(k W)\end{array}$ & $\begin{array}{r}\text { Energy } \\
19925\end{array}$ & $\begin{array}{r}\text { Demand } \\
19925\end{array}$ & $\begin{array}{c}\text { Total } \\
19925\end{array}$ & $\begin{array}{l}\text { First } \\
\text { Cost } \\
\$\end{array}$ & $\begin{array}{c}\text { O\&y } \\
\text { Savings } \\
\$\end{array}$ & $\begin{array}{l}\text { NPV } \\
1992 S\end{array}$ & $\begin{array}{l}\text { Value } \\
\text { Index }\end{array}$ & $\begin{array}{c}\text { NPV } \\
1992 \$\end{array}$ & $\begin{array}{l}\text { Value } \\
\text { Index }\end{array}$ \\
\hline $\begin{array}{l}1 \\
2 \\
3 \\
4 \\
5 \\
6 \\
7 \\
8\end{array}$ & $\begin{array}{r}169,584 \\
75,371 \\
376,856 \\
113,056 \\
598,360 \\
186,988 \\
219,832 \\
92,050\end{array}$ & $\begin{array}{l}0 \\
0 \\
0 \\
0 \\
0 \\
0 \\
0 \\
0\end{array}$ & $\begin{array}{r}7.806 \\
3.469 \\
17.348 \\
5.204 \\
27.544 \\
8.607 \\
10.119 \\
4.237\end{array}$ & $\begin{array}{l}0 \\
0 \\
0 \\
0 \\
0 \\
0 \\
0 \\
0\end{array}$ & $\begin{array}{r}7.806 \\
3.469 \\
17.348 \\
5.204 \\
27.544 \\
8,607 \\
10,119 \\
4.237\end{array}$ & $\begin{array}{r}21,495 \\
8,148 \\
37,744 \\
13,153 \\
56,820 \\
15,343 \\
19,276 \\
14,205\end{array}$ & $\begin{array}{l}\text { NA } \\
\text { NA } \\
\text { NA } \\
\text { NA } \\
\text { NA } \\
\text { MA } \\
\text { NA } \\
\text { NA }\end{array}$ & $\begin{array}{r}96,894 \\
43,064 \\
215,321 \\
64,596 \\
341,879 \\
106,838 \\
125,603 \\
52,594\end{array}$ & $\begin{array}{l}4.5 \\
5.3 \\
5.8 \\
4.9 \\
6.0 \\
6.9 \\
6.5 \\
3.7\end{array}$ & $\begin{array}{l}\text { NA } \\
\text { NA } \\
\text { NA } \\
\text { NA } \\
\text { NA } \\
\text { NA } \\
\text { NA } \\
\text { NA }\end{array}$ & $\begin{array}{l}\text { NA } \\
N A \\
N A \\
N A \\
N A \\
N A \\
N A \\
N A\end{array}$ \\
\hline
\end{tabular}


Table 6.10. Adjustable Speed Drive Exhaust Fan Motors

Existing exhaust fan motor operating parameters

\begin{tabular}{|c|c|c|c|c|}
\hline \multicolumn{3}{|c|}{ Existing Equipment } & \multicolumn{2}{|c|}{ Annual Energy Consumption } \\
\hline $\begin{array}{l}\text { Item } \\
\text { No. }\end{array}$ & Exhaust Fan Size & $\begin{array}{l}\text { No. of } \\
\text { Units }\end{array}$ & $\begin{array}{l}\text { Energy } \\
\text { (kWh) }\end{array}$ & $\begin{array}{l}\text { Demand } \\
\text { (kW/month) }\end{array}$ \\
\hline 1 & hp Fan & 2 & 31.494 & 0 \\
\hline 2 & 3 hp Fan & 1 & 22,612 & 0 \\
\hline 3 & 5 hp Fan & 4 & 149.200 & 0 \\
\hline 4 & $7.5 \mathrm{hp} \mathrm{Fan}$ & 4 & 221,524 & 0 \\
\hline 5 & 10 hp Fan & 2 & 145.870 & 0 \\
\hline 6 & 15 hp Fan & 2 & 215,438 & 0 \\
\hline 7 & 10 hp Fan & 1 & 72,935 & 0 \\
\hline
\end{tabular}

Efricient exhaust fan motor operating paraneters

\begin{tabular}{|c|c|c|c|c|c|}
\hline \multicolumn{4}{|c|}{ Energy Resource Opportunity } & \multicolumn{2}{|c|}{ Annual Energy Consumption } \\
\hline $\begin{array}{l}\text { Item } \\
\text { No. }\end{array}$ & $\begin{array}{l}\text { Exhau } \\
\text { (w/C }\end{array}$ & $\begin{array}{l}\text { st Fan Size } \\
\text { ontrol) }\end{array}$ & $\begin{array}{l}\text { No. of } \\
\text { Units }\end{array}$ & $\begin{array}{l}\text { Energy } \\
(k W h)\end{array}$ & $\begin{array}{l}\text { Demand } \\
\text { (kW/month) }\end{array}$ \\
\hline 1 & 2 & hp Fan & 2 & 14.968 & 0 \\
\hline 2 & 3 & hp Fan & 1 & 10.746 & 0 \\
\hline 3 & & hp Fan & 4 & 70.904 & 0 \\
\hline 4 & 7.5 & hp Fan & 4 & 105.276 & 0 \\
\hline 5 & 10 & hp Fan & 2 & 69.222 & 0 \\
\hline 6 & 15 & hp Fan & 2 & 102,382 & 0 \\
\hline 7 & 10 & hp Fan & 1 & 49.383 & 0 \\
\hline
\end{tabular}

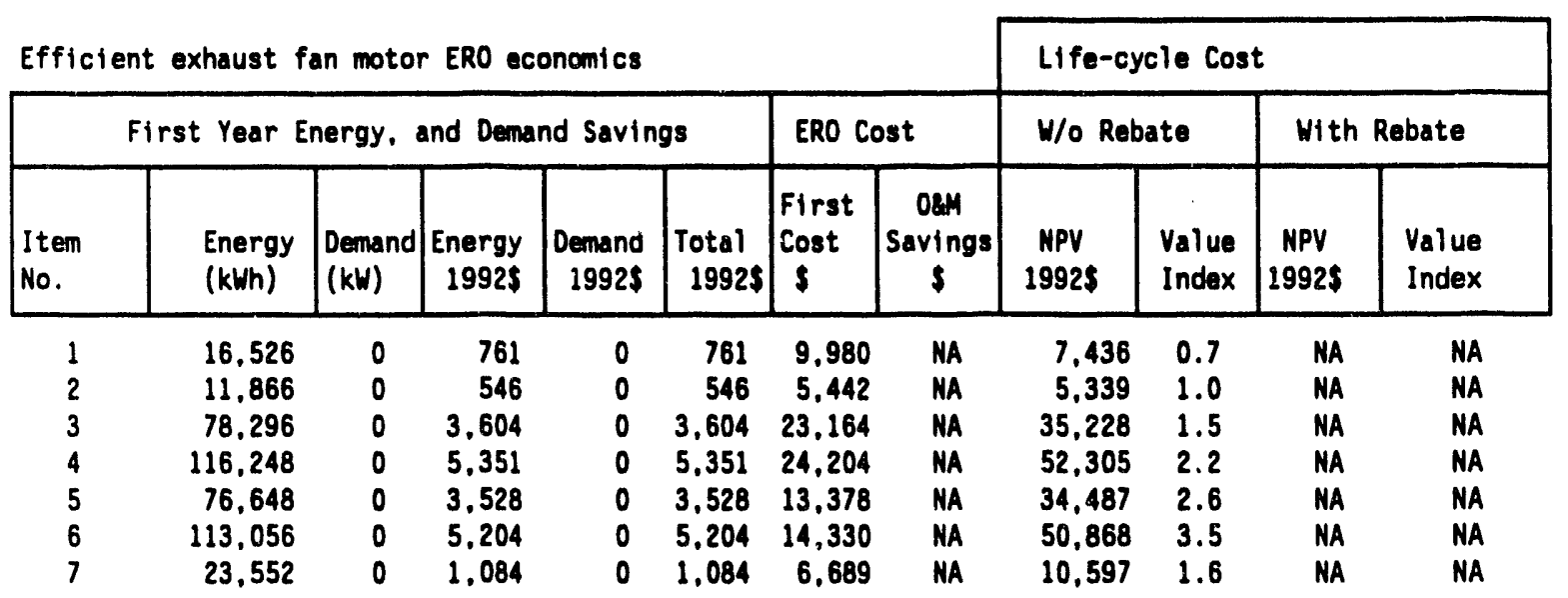

\section{Recommendations}

The reduction in fan speed associated with this ERO relates directly to substantial energy savings while maintaining occupant comfort with base level ventilation. Additional optimization of operating speed can be made by adjustments up or down to the $25 \%$ speed once the ASDs are installed. 
Because the AHUs are assigned to areas by zones, fine tuning can be accomplished for additional occupancy comfort and energy savings. An additional possible benefit of the ASD technology would be the use of reduced fan speed for load shedding. During times of possible utility load strains, or to shave demand peaks, fans could be run at lower than normal levels. This would maintain a base level of ventilation while reducing demand levels.

\subsubsection{Install Energy-Efficient Motors for Energy Plant Pumps}

\section{Description}

This ERO consists of immediately replacing standard electric motors with EE motors. The motors selected for analysis operate one-half to full time and are $2 \mathrm{hp}$ or larger. Some of the motors currently in use appear to be oversized for their application. These motors should also be downsized in addition to being replaced with energy-efficient models. Their power factor and efficiency would increase while the cost of the new EE motor would be less.

\section{Data and Assumptions}

The pumps considered for EE motor installation are listed in Table 6.11.

Table 6.11 Pump Motor Characteristics

\begin{tabular}{|c|c|c|c|c|c|c|}
\hline Item & $\begin{array}{l}\text { I.D. } \\
\text { No. } \\
\end{array}$ & Service & hp & $\begin{array}{c}\text { Efficiency } \\
(x) \\
\end{array}$ & $\begin{array}{c}\text { Operation } \\
\text { (time) }\end{array}$ & $\begin{array}{c}\text { Replacement } \\
\text { efficiency } \\
\text { (x) }\end{array}$ \\
\hline 1 & P-1004 & Condensate & 40 & 87.5 & $1 / 4$ & 93 \\
\hline 2 & $P-1005$ & Condensate & 40 & 87.5 & $1 / 4$ & 93 \\
\hline 3 & P-1010 & Hesting Coil & 60 & 90.2 & $1 / 2$ & 93.3 \\
\hline 4 & $P-1011$ & Heating Coll & 60 & 90.2 & $1 / 2$ & 93.3 \\
\hline 5 & $P-1026$ & Feedwater & 20 & 87.5 & $1 / 2$ & 91.6 \\
\hline 6 & $P-1027$ & Feedwater & 20 & 87.5 & $1 / 2$ & 91.6 \\
\hline 7 & $P-1101$ & DHW Booster & 20 & 87.5 & $1 / 4$ & 91.6 \\
\hline 8 & $P-1102$ & DHN Booster & $30(25)$ & 89.5 & $1 / 4$ & 92.8 \\
\hline 9 & P-1103 & DHN Booster & $30(25)$ & 89.5 & $1 / 4$ & 92.8 \\
\hline 10 & $P-1.104$ & DHW Booster & 20 & 87.5 & $1 / 4$ & 91.6 \\
\hline 11 & P-1105 & Booster & $5(3)$ & 80.5 & $1 / 4$ & 87 \\
\hline 12 & P-1106 & Booster & $5(3)$ & 80.5 & $1 / 4$ & 87 \\
\hline 13 & $P-1117$ & Booster & 25 & 87.5 & $3 / 4$ & 92.6 \\
\hline 14 & $P-1118$ & Booster & 3 & 80.1 & $1 / 2$ & 87.6 \\
\hline$\vdots 5$ & P-1012 & Aux. Cooling & $20(\vdots 5)$ & 87.5 & $1 / 2$ & 91.6 \\
\hline 16 & P-1013 & Aux. Cooling & $20 ! \cdot 15)$ & 87.5 & $1 / 2$ & 91.6 \\
\hline
\end{tabular}

Items 8, 9, 11, 12, 15, and 16 show downsized EE motors (recommended size in parenthesis). Many of the listed motors operate in pairs with one unit running at any given time. These include the sets of $1-2,3-4,5-6,7-10,8-9$, and 14-15. For these sets, the pump operation time shown is actually one-half the value for one motor only. Since it is not known which motor will operate at a given time, both units are considered to run one-half of the time. This also requires that the motor changeout costs include both units. 
Cost estimates are based on vendor quotes and labor estimates from MEANS Electrical Cost Data (R.S. Means Co., Inc. 1991a) and Energy-Efficient Motor Systems - A Handbook on Technology, Programs, and Policy Opportunities (Nadel et al. 1991).

\section{Results}

The results for this ERO appear in Table 6.12. If the motor pairs were considered primary with a backup situation, additional cost savings could be achieved by replacement of the primary unit only (one-half the total cost). These additional savings would be achieved only if the primary pump was predominantly used rather than alternated with the backup, as is usually the case.

\section{Recommendations}

Although this measure would save ernegy dollars, the initial cost of replacing of the motors is too high to justify immediate replacement, making this option not cost-effective (NPV $<0$ ). An alternative option to immediate replacement of the motors would be a replacement-on-failure program. This would replace each unit upon failure with an energy-efficient model. In effect, this would reduce the initial cost to the difference between a standard and energy-efficient motor.

Table 6.12. Energy-efficient Motor Upgrade

Existing pump motor operating parameters

\begin{tabular}{|c|c|c|c|c|}
\hline \multicolumn{3}{|c|}{ Sxisting Equipment } & \multicolumn{2}{|c|}{ Annual Energy Consumption } \\
\hline $\begin{array}{l}\text { Item } \\
\text { No. }\end{array}$ & Sup ply Fan Size & $\begin{array}{l}\text { No. of } \\
\text { Units }\end{array}$ & $\begin{array}{l}\text { Energy } \\
(\mathrm{kWh})\end{array}$ & $\begin{array}{c}\text { Denand } \\
\text { (kW/month) }\end{array}$ \\
\hline 1 & P-1004 & 1 & 49.815 & 22.8 \\
\hline 2 & P-1005 & 1 & 49,815 & 22.8 \\
\hline 3 & P-1010 & 1 & 130,409 & 29.8 \\
\hline 4 & $p-1011$ & 1 & 130,409 & 29.8 \\
\hline 5 & $p-1026$ & 1 & 24,870 & 5.7 \\
\hline 6 & $p-1027$ & 1 & 24,870 & 5.7 \\
\hline 7 & $P-1101$ & 1 & 24,646 & 11.2 \\
\hline 8 & P-1102 & 1 & 29.750 & 13.6 \\
\hline 9 & P-1103 & 1 & 29.750 & 13.6 \\
\hline 10 & P-1104 & 1 & 24.646 & 11.2 \\
\hline 11 & P-1105 & 1 & 3,958 & 1.8 \\
\hline 12 & P-1106 & 1 & 3,958 & 1.8 \\
\hline 13 & $P-1117$ & 1 & 92,423 & 14.1 \\
\hline 14 & $P-1118$ & 1 & 8,077 & 1.8 \\
\hline 15 & P-1012 & 1 & 35,476 & 8.1 \\
\hline 16 & $P-1013$ & 1 & 35.476 & 8.1 \\
\hline
\end{tabular}


Table 6.12. (contd)

Efficient pump motor operating parameters

\begin{tabular}{|c|c|c|c|c|}
\hline \multicolumn{3}{|c|}{ Energy Resource Opportunity } & \multicolumn{2}{|c|}{ Annual Energy Consumption } \\
\hline $\begin{array}{l}\text { Item } \\
\text { No. }\end{array}$ & $\begin{array}{l}\text { Supply Fan Size } \\
\text { (w/Control) }\end{array}$ & $\begin{array}{l}\text { No. of } \\
\text { Units }\end{array}$ & $\begin{array}{l}\text { Energy } \\
(\mathrm{kWh})\end{array}$ & $\begin{array}{l}\text { Demand } \\
\text { (kW/month) }\end{array}$ \\
\hline 1 & p-1004 & 1 & 46,869 & 21.4 \\
\hline 2 & $p-1005$ & 1 & 46,869 & 21.4 \\
\hline 3 & $p-1010$ & 1 & 126,076 & 28.8 \\
\hline 4 & $p-1011$ & $i$ & 126,076 & 28.8 \\
\hline 5 & $P-1026$ & 1 & 23.757 & 5.4 \\
\hline 6 & $p-1027$ & $i$ & 23.757 & 5.4 \\
\hline 7 & $P-1101$ & 1 & 23,543 & 10.8 \\
\hline 8 & $p-1102$ & 1 & 27.788 & 12.7 \\
\hline 9 & $P-1103$ & 1 & 27.788 & 12.7 \\
\hline 10 & $P-1104$ & 1 & 23,543 & 10.8 \\
\hline 11 & $p-1105$ & 1 & 3.740 & 1.7 \\
\hline 12 & $P-1106$ & 1 & 3.740 & 1.7 \\
\hline 13 & $p-1117$ & 1 & 87,333 & 13.3 \\
\hline 14 & $P-1118$ & 1 & 7.385 & 1.7 \\
\hline 15 & $p-1012$ & 1 & 33.932 & 7.7 \\
\hline 16 & $p-1013$ & 1 & 33.932 & 7.7 \\
\hline
\end{tabular}

\begin{tabular}{|c|c|c|c|c|c|c|c|c|c|c|c|}
\hline \multicolumn{8}{|c|}{ Efficient pump motor ERO economics } & \multicolumn{4}{|c|}{ Life-cycle Cost } \\
\hline \multicolumn{6}{|c|}{ First Year Energy, and Demand Savings } & \multicolumn{2}{|c|}{ ERO Cost } & \multicolumn{2}{|c|}{ W/o Rebate } & \multicolumn{2}{|c|}{ With Rebate } \\
\hline $\begin{array}{l}\text { Item } \\
\text { No. }\end{array}$ & $\begin{array}{l}\text { Energy } \\
\text { (kWh) }\end{array}$ & $\begin{array}{l}\text { Demand } \\
(k W)\end{array}$ & $\begin{array}{r}\text { Energy } \\
1992 \$\end{array}$ & $\begin{array}{l}\text { Demand } \\
19925\end{array}$ & $\begin{array}{c}\text { Total } \\
\text { 1992\$ }\end{array}$ & $\mid \begin{array}{l}\text { First } \\
\text { Cost } \\
\rho\end{array}$ & $\begin{array}{c}\text { O\&M } \\
\text { Savings } \\
\$\end{array}$ & $\begin{array}{l}\text { NPV } \\
1992 \$\end{array}$ & $\begin{array}{l}\text { Value } \\
\text { Index }\end{array}$ & $\begin{array}{l}\text { NPV } \\
1992 \$\end{array}$ & $\begin{array}{l}\text { Value } \\
\text { Index }\end{array}$ \\
\hline 1 & 2,946 & 16.8 & 150 & 86 & 236 & 2,247 & NA & (148) & NA & NA & NA \\
\hline 2 & 2.946 & 16.8 & 150 & 86 & 236 & 2.247 & NA & (148) & NA & NA & NA \\
\hline 3 & 4,333 & 12 & 221 & 61 & 282 & 3.941 & NA & (217) & NA & NA & NA \\
\hline 4 & 4,333 & 12 & 221 & 61 & 282 & 3,941 & NA & (217) & NA & NA & NA \\
\hline 5 & 1,113 & 3.6 & 57 & 18 & 75 & 1.252 & NA & (56) & NA & NA & NA \\
\hline 6 & 1.113 & 3.6 & 57 & 18 & 75 & 1.252 & NA & (56) & NA & NA & NA \\
\hline 7 & 1.103 & 4.8 & 56 & 24 & 80 & 1,252 & NA & (55) & NA & NA & NA \\
\hline 8 & 1.962 & 10.8 & 99 & 55 & 154 & 1.586 & HA & (98) & NA & NA & NA \\
\hline 9 & 1,962 & 10.8 & 99 & 55 & 154 & 1,586 & NA & (98) & NA & NA & NA \\
\hline 10 & 1.103 & 4.8 & 56 & 24 & 80 & 1.252 & NA & (56) & NA & NA & NA \\
\hline 11 & 218 & 1.2 & 11 & 6 & 17 & 457 & NA & (12) & NA & NA & NA \\
\hline 12 & 218 & 1.2 & 11 & 6 & 17 & 457 & NA & (12) & $N A$ & $N A$ & $N A$ \\
\hline 13 & 5.090 & 9.6 & 259 & 49 & 308 & 1,586 & MA & (255) & NA & NA & NA \\
\hline 14 & 692 & 1.2 & 35 & 6 & 41 & 457 & NA & (35) & NA & NA & NA \\
\hline 15 & 1,544 & 4.8 & 79 & 24 & 103 & 1.068 & NA & (77) & NA & NA & NA \\
\hline 16 & 1.544 & 4.8 & 79 & 24 & 103 & 1.068 & NA & (77) & NA & NA & NA \\
\hline
\end{tabular}

\subsection{Boiler and Building Structure EROs}

This section presents the analysis and recommendations for two EROs involving the operation of 
the boilers and ventilation losses through the loading dock opening.

\subsubsection{Boiler Oxygen Reset}

\section{Description}

All three boilers are new (less than four years old) and are generally well maintained. Operational changes can usually "fine tune" equipment or processes, resulting in energy savings. At DGMC, excess combustion air was noted as a possible energy reduction opportunity. The trimming of excess oxygen flow results in increased combustion efficiency leading to energy use reduction.

\section{Data and Assumptions}

Data from the boiler logs indicates an average excess oxygen $\left(\mathrm{O}_{2}\right)$ level of $5.44 \%$ in the flue gas:

Month / Year

April 1991

July 1991

October 1991

January 1992

May 1992

\section{Excess $0_{20} \%$}

5.0 and 5.9

5.9 and 6.0

5.5 and 5.0

4.9 and 5.3

5.5 (one boiler operation)

$$
\text { Average }=\quad 49 / 9=5.44
$$

The average combustion efficiency with $5.44 \%$ excess $\mathrm{O}_{2}$ is considered to be approximately 83.8\%. This leads to an excess air estimate of $40 \%$ with $8.3 \% \mathrm{CO}_{2}$ and $6.3 \%$ dry $\mathrm{O}_{2}$. Reducing the $\mathrm{O}_{2}$ in the flue gas to $2.5 \%$ will increase combustion efficiency one percentage point (to $84.8 \%$ ) with excess air at about $15 \%, \mathrm{CO}_{2}$ at $10.3 \%$ by volume, and $3 \%$ dry $\mathrm{O}_{2}$. Based on this information, an estimate of the possible reduction in natural gas use is set at $1.2 \%$ of the current use.

\section{Analysis Results}

The results of the life-cycle cost analysis of this option appear in Table 6.13.

\section{Budget Information}

There is virtually no cost associated with this ERO because it is a quick boiler adjustment. 
Table 6.13. Boiler Oxygen Reset

Existing boiler operating parameters

\begin{tabular}{|l|l|l|l|}
\hline \multicolumn{2}{|c|}{ Existing Equipment } & Annual Gas Consumption \\
\hline $\begin{array}{l}\text { Item } \\
\text { No. }\end{array}$ & Equipment Type & $\begin{array}{l}\text { No. of } \\
\text { Units }\end{array}$ & $\begin{array}{c}\text { Natural Gas } \\
\text { (kcf) }\end{array}$ \\
\hline
\end{tabular}

1 Gas Boiler $\quad 4 \quad 86,030$

Efficient boiler operating parameters

\begin{tabular}{|l|l|l|l|}
\hline \multicolumn{2}{|l|}{ Energy Resource Opportunity } & Annual Gas Consumption \\
\hline Item & $\begin{array}{l}\text { Efficient } \\
\text { No. }\end{array}$ & $\begin{array}{l}\text { No. of } \\
\text { Enipment Type }\end{array}$ & $\begin{array}{c}\text { Natural Gas } \\
\text { (kcf) }\end{array}$ \\
\hline
\end{tabular}

1 Gas Boiler $w / \mathrm{O}_{2}$ Trim $4 \quad 84,998$

\begin{tabular}{|c|c|c|c|c|c|c|}
\hline \multicolumn{5}{|c|}{ Efficient boiler ERO economics } & \multicolumn{2}{|c|}{ Life-cycle Cost } \\
\hline \multicolumn{3}{|c|}{ First Year Energy Savings } & \multicolumn{2}{|c|}{ ERO Cost } & \multicolumn{2}{|c|}{ W/o Rebate } \\
\hline $\begin{array}{l}\text { Item } \\
\text { No. }\end{array}$ & $\begin{array}{l}\text { Natural Gas } \\
\text { (kcf) }\end{array}$ & $\begin{array}{c}\text { Total } \\
\text { Natural Gas } \\
\text { 1992\$ }\end{array}$ & $\begin{array}{l}\text { First } \\
\text { Cost } \\
\$\end{array}$ & $\begin{array}{c}\text { Osu } \\
\text { Savings } \\
\text { S/year }\end{array}$ & $\begin{array}{c}\text { NPV } \\
1992 \$\end{array}$ & $\begin{array}{l}\text { Value } \\
\text { Index }\end{array}$ \\
\hline 1 & 1,032 & 2.936 & $\sim$ & 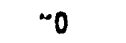 & 55,313 & $\star \star \star$ \\
\hline
\end{tabular}

\section{Energy and Cost Savings}

Estimated energy savings would be $1.2 \%$ of the natural gas consumed by the three boilers. The annual consumption of the three boilers would be 86,030 kef (meters GM-1001, -1002, and -1003) as shown in Table 2.8. The total reduction in natural gas use would be $1032 \mathrm{kcf}$ at an annual cost savings of $\$ 2,936$.

\section{Operation and Maintenance Impacts}

Operations and maintenance will have no appreciable change with implementation of this ERO.

\section{Recommendations}

Because excess oxygen trim is an easy and very cost-effective option it should be implemented immediately. Oxygen level checks should be made to ensure that it neither rises or falls. A rise 
would mean excessive use of fuel and a fall might indicate too lean a mixture causing unnecessary stack pollution.

\subsubsection{Install Infiltration Air Curtain}

\section{Description}

The loading dock entrance presently allows large quantities of outside air into the building. Installing an air curtain at the loading dock entrance will reduce both the cooling load in the summer and heating load in the winter. Another key benefit in installing this air curtain would be the reduction of outdoor air contaminants that would otherwise enter the hospital (i.e., dust, pollen, vehicle exhaust). At this time, the loading dock has double doors at two locations. They are actuated by touch control. These doors have magnetic latches that keep the doors open during receipt of supplies from the loading dock. This would be the only access to the kitchen and dining room stores and supplies. The magnetic latch is tied in with the hospital fire control system. Both double doors

are usually left open during part of the day. Infiltration is high because of the pressure differential of the hospital.

\section{Data and Assumptions}

The doors are assumed to be left open $1 \mathrm{~h} / \mathrm{d}$. The cooling and heating loads based on an air velocity of $350 \mathrm{ft} / \mathrm{min}$ amounts to $14,700 \mathrm{ft}^{3} / \mathrm{min}$ (6- $\mathrm{ft} \times 7-\mathrm{ft}$ opening). The estimated cooling and heating load savings are $18.8 \mathrm{MBtu} / \mathrm{yr}$ and $18.5 \mathrm{MBtu} / \mathrm{yr}$, respectively. Both the cooling and heating loads (sensible and latent) were obtained using calculations from the ASHRAE Handbook (ASHRAE 1989). The total first cost for implementing this ERO would be $\$ 1,254$. This includes the cost of material and labor to install the air curtain and its on-off control. Cost estimates are based on the MEANS Mechanical Cost Data (R.S. Means Co., Inc. 1991b) and manufacturers data.

\section{Analysis Results}

The results from this analysis are shown in Table 6.14.

\section{Budget Information}

The total first cost of implementing this ERO would be $\$ 1,254$.

\section{Operation and Maintenance Impacts}

Maintenance would be minimal on the air curtain electric motor. 


\section{Energy and Cost Saving}

The cooling load electrical savings would amount to $5,508 \mathrm{kWh} / \mathrm{yr}$ with heating load natural gas savings of $18.0 \mathrm{kcf}$. Cost savings are estimated to be $\$ 280$ for electricity and $\$ 51$ for gas in a typical year, for a total of $\$ 331 / y r$.

Table 6.14. Air Curtain at Loading Door

Existing door operating parameters

\begin{tabular}{|l|l|l|l|c|}
\hline \multicolumn{3}{|c|}{ Existing Equipment } & \multicolumn{2}{|c|}{ Annual Energy Consumption } \\
\hline $\begin{array}{l}\text { Item } \\
\text { No. }\end{array}$ & Equipment Type & $\begin{array}{c}\text { No. of } \\
\text { Units }\end{array}$ & $\begin{array}{c}\text { Natural Gas } \\
\text { (kef) }\end{array}$ & $\begin{array}{c}\text { Elec. } \\
\text { (kWh) }\end{array}$ \\
\hline
\end{tabular}

1 Double Loading Door 2 (See Net Value Below)

Efficient door operating parameters

\begin{tabular}{|l|l|l|l|c|}
\hline \multicolumn{2}{|c|}{ Energy Resource Opportunity } & \multicolumn{2}{|c|}{ Annual Energy Consumption } \\
\hline $\begin{array}{l}\text { Item } \\
\text { No. }\end{array}$ & $\begin{array}{l}\text { Efficient } \\
\text { Equipment Type }\end{array}$ & $\begin{array}{l}\text { No. of } \\
\text { Units }\end{array}$ & $\begin{array}{c}\text { Natural Gas } \\
\text { (kcf) }\end{array}$ & $\begin{array}{c}\text { Elec. } \\
\text { (kWh) }\end{array}$ \\
\hline 1 & Door w/Air Curtain & 2 & \multicolumn{2}{|c|}{ (See Net Value Below) }
\end{tabular}

\begin{tabular}{|c|c|c|c|c|c|c|c|c|c|}
\hline \multicolumn{8}{|c|}{ Efficient door ERO economics } & \multirow{2}{*}{\multicolumn{2}{|c|}{$\frac{\text { Life-cycle Cost }}{\text { W/o Rebate }}$}} \\
\hline \multicolumn{6}{|c|}{ First Year Energy Savings } & \multicolumn{2}{|c|}{ ERO Cost } & & \\
\hline $\begin{array}{l}\text { Item } \\
\text { No. }\end{array}$ & $\begin{array}{c}\text { Gas } \\
\text { (kcf) }\end{array}$ & $\begin{array}{l}\text { Elec. } \\
\text { (kwh) }\end{array}$ & $\begin{array}{c}\text { Gas } \\
\text { 19925 }\end{array}$ & $\begin{array}{l}\text { Elec. } \\
\text { 1992s }\end{array}$ & $\begin{array}{l}\text { Total } \\
1992 S\end{array}$ & $\begin{array}{l}\text { First } \\
\text { Cost } \\
\$\end{array}$ & $\begin{array}{c}\text { OelM } \\
\text { Savings } \\
\text { S/year }\end{array}$ & $\begin{array}{c}\text { NPV } \\
19925\end{array}$ & $\begin{array}{l}\text { Value } \\
\text { Index }\end{array}$ \\
\hline 1 & 18.0 & 5,508 & 51 & 280 & 331 & 1,254 & $\sim 0$ & 3,811 & 3.04 \\
\hline
\end{tabular}

\section{Recommendations}

Because the air curtain technology involves no physical barriers other than air, there should be minimal interference with normal operations, and this ERO should be a very cost-effective energysaving option. Prior to installation, the issue of the large building pressure differential must be addressed to ensure that the chosen air curtain is designed to meet that load.

\subsection{Electricity Demand-Reduction EROs}

Electricity demand at the medical center might be reduced by several primary methods available at the site. The first method involves the use of the existing KTA38-G1 Cummins emergency 
generators for peak shaving. Operation would be during the summer peak period only. Other options involve the utilization of emergency generator coolant and exhaust gas waste heat for cogeneration. This waste heat would power an absorption chiller, which would help in supplying chilled water to the hospital's chilled water cooling system. An additional option involves the use of direct or indirect gas-fired absorption chillers for similar supplementation of the chilled water system.

\subsubsection{Electric Load Peak Shaving Using Emergency Generators}

\section{Description}

The six emergency generators are presently checked out once each week without load, and once a month at $80 \%$ load for a total of approximately $64 \mathrm{~h} / \mathrm{yr}$. The generators are on standby the rest of the year. Utilizing three of the six Cummins diesel generators for peak shaving will reduce the hospital's electricity cost. The three generators will operate during the servicing utility's summer peak period (May 1 through October 31) from 1130 through 1830, Monday through Friday (except holidays). The half-hour start and stop before and after the actual peak period is a safety margin and system stabilization period. All six units will be used with alternating schedules. This will permit servicing of generators while three are operational.

\section{Data and Assumptions}

The yearly operating hours subject to the utility peak conditions noted above total $889 \mathrm{~h} / \mathrm{yr}$. Each unit will operate at $600 \mathrm{~kW}$ electrical output for savings as follows:

- energy savings $=1,600,200 \mathrm{kWh} / \mathrm{yr}$

- demand savings $=1,800 \mathrm{~kW}$.

The total estimated cost of switch materials, equipment, and labor necessary to affect the efficient tie-in of the generators to the hospital power supplies would be $\$ 10,000$. Since the planned operation of the emergency generators exceeds $100 \mathrm{~h} / \mathrm{yr}$, and is to be used for purposes other than emergency generation, the BAAQMD ${ }^{(a)}$ requirements for emissions go into effect. These requirements include:

- Application for permit to operate (considered full time) the emergency generators at the conditions specified, which are 1130 to 1830, Monday through Friday, from May 1 through October 31 , except holidays.

- BAAQMD will evaluate the permit application. The best available control technology (BACT) limits are

(a) Telephone conversations with Greg Solomon and Dennis Jang of the Bay Area Air Quality Management District, San Francisco, California, 1982. 
- Nitrous Oxides $\left(\mathrm{NO}_{\mathrm{x}}\right)=0.75 \mathrm{~g} / \mathrm{hp} \cdot \mathrm{hr}$

- Organics $=1.5 \mathrm{~g} / \mathrm{hp} \cdot \mathrm{h}$

- Carbon Monoxide (CO) $=2 \mathrm{~g} / \mathrm{hpohr}$

- If emissions exceed the BAAQMD limits, options to abate, including selective catalytic reduction (SCR), can be reviewed and analyzed.

Exhaust emissions data were obtained from a telephone conversation with representatives of the Cummins Engine Company, Inc. are as follows:

- $\mathrm{NO}_{\mathrm{x}}=10.46 \mathrm{~g} / \mathrm{hp} \mathrm{h}$

- Organics $(\mathrm{HC})=0.08 \mathrm{~g} / \mathrm{hp} \cdot \mathrm{hr}$

- $\mathrm{CO}=0.82 \mathrm{~g} / \mathrm{hp} \cdot \mathrm{h}$.

The estimated $\mathrm{NO}_{\mathrm{x}}$ emissions currently exceed the BACT limit and, therefore, the BAAQMD would not permit operation of the emergency generators for peak sharing or as cogeneration units without emission control. To go from 10.46 to $0.75 \mathrm{~g} / \mathrm{hpoh}$ requires a reduction of $93 \% \mathrm{NO}_{\mathrm{x}}$. There are $\mathrm{NO}_{\mathrm{x}}$ reduction devices that reduce this component by $97 \%$, which would meet the BACT limits. These devices include the use of ammonia injection, powder injection, and selective catalytic reduction. Estimated costs for this mitigation are approximately $\$ 67,000 /$ unit or $\$ 402,000$ total. Adding the $\$ 10,000$ tie-in cost shows a total implementation cost for this ERO of $\$ 412,000$. The fuel oil required to operate the emergency generators is as follows:

- After deducting the fuel consumed for the weekly check-out runs during the six summer months, the additional fuel oil consumed equals fuel consumed by the three generators - fuel used during the weekly check-out tests $=117,348-2,124=115,224 \mathrm{gal} / \mathrm{yr}$.

Operation and maintenance costs will increase because of additional generator operating hours and care of emissions-mitigation equipment. The estimated changes in O\&M costs are as follows:

- increase in operating hours $=889-32=857 \mathrm{~h}$

- generator operator cost $=857 \mathrm{~h} / \mathrm{yr} \times \$ 25 / \mathrm{h}=\$ 21,435 / \mathrm{yr}$

- increase in maintenance cost:

$$
\begin{aligned}
& \text { maintenance factor }=\frac{857 \mathrm{~h} / \mathrm{yr}}{250 \mathrm{~h}} \text { between servicing }=3.43 \\
& \text { material cost }=\$ 200 / \text { unit } \times 3 \text { units }=\$ 600 \\
& \text { labor cost }=2 \mathrm{~h} / \text { unit } \times 3 \text { units } \times \$ 25 / \mathrm{h}=\$ 150 \\
& \text { total generator maintenance cost }=(\$ 600+\$ 150) 3.43=\$ 2,573 / \mathrm{yr} \text {. }
\end{aligned}
$$


Total mitigation maintenance per year is estimated at $\mathbf{\$ 2 . 4 3 / o p e r a t i n g ~ h o u r ~ b a s e d ~ o n ~ s i m i l a r ~}$ costs at other facilities. At a total operation of $889 \mathrm{~h} / \mathrm{yr}$ for three units, the maintenance is estimated at $\$ 6480 / y r$.

total maintenance cost increase $=\$ 9,053$.

If the medical center decides to implement peak shaving with their generators, they must also incur PG\&E's standby service charges in order to maintain backup capacity in the event of generator failures. The PG\&E standby service (Schedule S) charge would be $\$ 0.60 / \mathrm{kW}$ applied to $85 \%$ of the ccntract capacity with a 12-month ratchet period. At a contracted amount of $1800 \mathrm{~kW}$, this would ancount to $1,800 \times .85 \times \$ 0.60 \times 12=\$ 11,016 / y r$.

At approximately 900 hours of operation per year, the generator units may not last longer than 15 years. The cost of replacement of the units at 15-year periods is included in the analysis.

\section{Analysis Results}

Results of the analysis of this ERO are shown in Table 6.15. Unlike previous ERO analyses, this life-cycle cost analysis does include the benefits of electricity demand reduction. This is because of the relatively large contribution of demand reduction in the total savings. Unlike other EROs, demand reduction is the primary source of savings.

\section{Budget Information}

The total first cost of this ERO would be $\$ 412,000$ for the emissions-mitigation equipment and hospital electrical supply tie in.

\section{Operation and Maintenance Impacts}

The cost of O\&M would be expected to increase by $\$ 41,504 / y r$ for operator time, increased labor and materials for routine maintenance on the units in use, and associated emissions-mitigation costs. Also included in the total would be the $\$ 11,016 /$ yr utility electric capacity standby service fee.

\section{Energy Demand and Cost Savings}

Energy reduction as a result of the peak shaving use of the generators is estimated at $1,600,200$ $\mathrm{kWh}$ at a cost savings of $\$ 81,450$. Peak shaving demand savings is expected to be $1,800 \mathrm{~kW} / \mathrm{mo}$ in the summer for a savings of $\$ 103,680$. Total yearly savings are expected to be $\$ 185,130$. 
Table 6.15. Peak Shaving With Emergency Generators

Existing electricity use

\begin{tabular}{|l|l|l|l|}
\hline \multicolumn{2}{|c|}{ Existing Condition } & \multicolumn{2}{|c|}{ Annual Energy Consumption } \\
\hline $\begin{array}{l}\text { Item } \\
\text { No. }\end{array}$ & Energy Use Area & $\begin{array}{l}\text { Energy } \\
(\mathrm{kWh})\end{array}$ & $\begin{array}{l}\text { Demand } \\
(\mathrm{kW} / \mathrm{yr})\end{array}$ \\
\hline 1 & DGMC Med Center & $22,946,000$ & 24,311
\end{tabular}

Electricity use with peak shaving

\begin{tabular}{|l|l|l|l|}
\hline \multicolumn{2}{|l|}{ Energy Resource Opportunity } & \multicolumn{2}{|l|}{ Annual Energy Consumption } \\
\hline $\begin{array}{l}\text { Item } \\
\text { No. }\end{array}$ & $\begin{array}{l}\text { Energy Use Area } \\
\text { W/Peak Shaving }\end{array}$ & $\begin{array}{l}\text { Energy } \\
(\mathrm{kWh})\end{array}$ & $\begin{array}{l}\text { Demand } \\
(\mathrm{kW} / \mathrm{yr})\end{array}$ \\
\hline
\end{tabular}

1 DGMC Med Center 21,345,800 13,511

\begin{tabular}{|c|c|c|c|c|c|c|c|c|c|c|}
\hline \multicolumn{9}{|c|}{ Electricity use with peak shaving ERO sconomics } & \multicolumn{2}{|c|}{ Life-cycle Cost } \\
\hline \multicolumn{6}{|c|}{ First Year Energy and Demand Savings } & \multicolumn{3}{|c|}{ ERO Cost } & \multicolumn{2}{|c|}{ W/o Rebate } \\
\hline $\begin{array}{l}\text { Item } \\
\text { No. }\end{array}$ & $\begin{array}{l}\text { Energy } \\
\text { (kWh) }\end{array}$ & $\begin{array}{l}\text { Demand } \\
(\mathrm{kW})\end{array}$ & $\begin{array}{r}\text { Energy } \\
1992 \$\end{array}$ & $\begin{array}{r}\text { Demand } \\
1992 \$\end{array}$ & $\begin{array}{c}\text { Total } \\
19925\end{array}$ & $\begin{array}{l}\text { First } \\
\text { Cost } \\
5\end{array}$ & $\begin{array}{c}\text { Fuel } \\
\text { Cost } \\
5\end{array}$ & $\begin{array}{c}\text { OaM } \\
\text { Savings } \\
s\end{array}$ & $\begin{array}{l}\text { NPV } \\
1992 \$\end{array}$ & $\begin{array}{l}\text { Value } \\
\text { Index }\end{array}$ \\
\hline 1 & $1,600,200$ & 10,800 & 81.450 & 103,680 & 185,13 & 412.00 & 87.57 & $(41,504)$ & 124,3 & 0.30 \\
\hline
\end{tabular}

\section{Recommendations}

This ERO can have a large impact on the medical center's energy, and most importantly, electricity demand use. All factors must be considered to ensure that backup emergency power supplies are not compromised.

\subsubsection{Peak Shaving with Jacket Coolant Cogeneration}

\section{Description}

This ERO applies only if the emergency generators are used to peak shave. The waste heat from the jacket coolant can be utilized to power a 100-ton absorption chiller, thus operating the system as a cogeneration unit. This would reduce electricity demand while reducing current fuel consumption for hot water supply. 


\section{Data and Assumptions}

The data and assumptions detailed in Section 6.4.1 also apply here with respect to the use of the generators for peak shaving. The additional information presented here applies to the use of the jacket cooling waste heat recovery.

The operating time of the cogeneration unit is based on $6.5 \mathrm{~h} / \mathrm{d}$ instead of $7 \mathrm{~h}$ to allow for temperature uniformity and stabilization. Manifolding of the jacket coolant water will permit operation of any three emergency generators at a given time. The values below are incremental to the peak shaving option in Section 6.4.1 and are, therefore, added to those values for the analysis.

The total first cost of implementing the cogeneration part of this ERO would be $\$ 148,915$. This estimate is based on installing a 100-ton absorption unit and required piping and valves to tie into the chilled water and condenser water loops. The cost estimate is as follows:

$$
\begin{array}{lc}
\text { Material }= & \$ 90,378 \\
\text { Labor }= & 38,398 \\
20 \% \text { engineering design and support }= & \frac{25,755}{\$ 154,531} \\
\quad \text { Total cost }= &
\end{array}
$$

The cost estimate is based on data from MEANS Mechanical Cost Data (R.S. Means Co., Inc. 1991b) and manufacturer's information. The total hours of operation for the cogeneration unit would be $127 \mathrm{~d} \times 6.5 \mathrm{~h} / \mathrm{d}=826 \mathrm{~h} / \mathrm{yr}$. The additional energy savings is based on reduced mechanical chiller (existing) operation, deletion of emergency generator radiator fans (10 hp each), and addition of required energy to run the 100-ton absorption chiller. The estimated incremental savings (additional to the savings achieved in Section 6.4.1) are as follows:

- energy savings $=137,200 \mathrm{kWh} / \mathrm{yr}$

- demand savings $=166 \mathrm{~kW}$ (996 over the six-month peak season)

Fuel costs for the chiller would be minimal because the absorption unit uses the waste heat from the emergency generators. Increased operational cost is estimated at $\$ 5,162 / \mathrm{yr}$ and maintenance cost at $\$ 3,750 / y r$, for a total additional O\&M cost of $\$ 8,912 / y r$.

\section{Analysis Results}

The results of the analysis of this ERO are shown in Table 6.16. Similar to the first peak shaving ERO (see Section 6.4.1), this life-cycle cost analysis includes the benefits of electricity demand reduction. This is done because of the relatively great contribution of demand reduction in the total savings. 
Table 6.16. Peak Shaving With Jacket Waste Heat Cogeneration

Existing chiller use

\begin{tabular}{|c|c|c|c|}
\hline \multicolumn{2}{|r|}{ Existing Condition } & \multicolumn{2}{|c|}{ Annual Energy Consumption } \\
\hline $\begin{array}{l}\text { Item } \\
\text { No. }\end{array}$ & Chiller Cooling Area & $\begin{array}{l}\text { Energy } \\
(k W h)\end{array}$ & $\begin{array}{l}\text { Demand } \\
(k W / y r)\end{array}$ \\
\hline
\end{tabular}

1 DGMC Med Center (See Net Value Below)

Peak shaving w/Jacket waste heat cogeneration

\begin{tabular}{|l|l|l|l|}
\hline \multicolumn{2}{|l|}{ Energy Resource Opportunity } & \multicolumn{2}{|l|}{ Annual Enorgy Consumption } \\
\hline Item & Cooling With Waste & $\begin{array}{l}\text { Energy } \\
\text { No. }\end{array}$ & Heat From Cogeneration \\
(kWh) & (kW/yr) \\
\hline
\end{tabular}

1 DGMC Med Center (See Net Value Below)

\begin{tabular}{|c|c|c|c|c|c|c|c|c|c|c|}
\hline \multicolumn{9}{|c|}{ Peak shaving w/jacket waste heat cogeneration ERO economics } & \multicolumn{2}{|c|}{ Life-cycle Cost } \\
\hline \multicolumn{6}{|c|}{ First Year Energy and Demand Savings } & \multicolumn{3}{|c|}{ ERO Cost } & \multicolumn{2}{|c|}{ W/o Rebate } \\
\hline $\begin{array}{l}\text { Item } \\
\text { No. }\end{array}$ & $\begin{array}{l}\text { Energy } \\
\text { (kWh) }\end{array}$ & $\begin{array}{l}\text { Demand } \\
(\mathrm{kW})\end{array}$ & \begin{tabular}{|r} 
Energy \\
19925
\end{tabular} & $\begin{array}{l}\text { Demand } \\
1992 \$\end{array}$ & $\begin{array}{c}\text { Total } \\
1992 \$\end{array}$ & $\begin{array}{l}\text { First } \\
\text { Cost } \\
5\end{array}$ & $\begin{array}{c}\text { Fuel } \\
\text { Cost } \\
\$\end{array}$ & $\begin{array}{c}\text { Osu } \\
\text { Savings } \\
\$\end{array}$ & $\begin{array}{c}\text { NPV } \\
19925\end{array}$ & $\begin{array}{l}\text { Value } \\
\text { Index }\end{array}$ \\
\hline 1 & $1,737.400$ & 11.796 & 88,434 & 113,242 & 201.676 & 566.53 & 87.57 & $(50,416)$ & 81.8 & 0.14 \\
\hline
\end{tabular}

\section{Budget Information}

Total first costs are estimated at \$566,531 for installation of a 100-ton chiller and associated piping and controls, as well as the peak shaving equipment detailed in Section 6.4.1.

\section{Operation and Maintenance Impacts}

The incremental operational costs of the new chiller system are estimated at $\$ 5,162 / \mathrm{yr}$. Associated increased maintenance costs are estimated at $\$ 3,750 / y r$. The total increased O\&M cost is estimated at $\$ 8,912 / \mathrm{yr}$, for a peak shaving plus heat recovery total of $\$ 50,416 / \mathrm{yr}$.

\section{Energy, Demand, and Cost Savings}

Total yearly energy savings for peak shaving plus heat recovery is estimated at $1,737,400 \mathrm{kWh}$ with demand savings of $11,796 \mathrm{~kW}$. Corresponding energy and demand savings amount to $\$ 88,434$ and $\$ 113,242$, respectively, for a total of $\$ 201,676$. 


\section{Recommendations}

This ERO has a lower NPV and VI than peak shaving alone, but could still be considered a valuable part of a combined emergency generator package project. This option involves higher initial costs and maintenance, but produces greater savings at a cost-effective level. If funding is available, this option should be considered in place of peak shaving alone. Considerations of increased maintenance and system complexity should be considered along with potential energy savings.

\subsubsection{Peak Shaving With Jacket Coolant And Exhaust Gas Cogeneration}

\section{Description}

This ERO also applies only if the emergency generators are used to peak shave. This analysis is similar to that in Section 6.4.2, but includes the additional costs and savings associated with exhaust gas heat recovery from the peak shaving generator operation. The waste heat from both the jacket coolant and exhaust can be utilized to power an absorption chiller, thus operating the system as a cogeneration unit.

\section{Data and Assumptions}

Discussions with several major cogeneration and heat recovery companies indicate that problems with fouling and damper control have all but eliminated this heat source as a practical cogeneration option. However, this option is analyzed here for the sake of completeness. An appropriate bare-fire tube-exhaust waste heat recovery silencer, complete with aluminum-jacketed blanket insulation and a soot chaser water injection tube cleaning system, was found to be available for the existing generators. These units could be installed on each emergency generator unit for heat recovery.

The diesel engine exhaust mass flow of $5700 \mathrm{lb} / \mathrm{h}$ at $860^{\circ} \mathrm{F}$ will supply $200^{\circ} \mathrm{F}$ hot water at 30 psig design pressure. The anticipated recoverable exhaust heat is $744,192 \mathrm{Btu} / \mathrm{h}$ with an exhaust gas pressure drop of $5 \mathrm{in}$. water column. This additional heat recovery requires the installation of a nominal 200-ton chiller instead of the 100-ton unit described in Section 6.4.2.

The following savings and costs are incremental in that they are additional costs associated with the exhaust heat recovery and must be added to the values used in Section 6.4 .2 for complete analysis of this option.

The additional cooling using this heat source is 62 tons with additional estimated savings as follows:

- energy savings $=75,992 \mathrm{kWh} / \mathrm{yr}$

- demand savings $=92 \mathrm{~kW}(552 \mathrm{~kW} / \mathrm{mo}$ over the six-month peak season). 
The additional installation cost estimate is as follows:

\begin{tabular}{|c|c|c|}
\hline Material & $\$ 227,170$ & $\begin{array}{l}\text { ( } \$ 60,170 \text { incremental chiller cost plus } \$ 167,000 \\
\text { exhaust recovery cost) }\end{array}$ \\
\hline Labor & $\$ 85,617$ & $\begin{array}{l}\text { ( } \$ 15,147 \text { incremental chiller cost plus } \$ 70,470 \text { exhaust } \\
\text { recovery cost) }\end{array}$ \\
\hline Engineering design & $\$ 22.717$ & $\begin{array}{l}\text { ( } \$ 6,017 \text { incremental chiller cost plus } \$ 16,700 \text { exhaust } \\
\text { recovery cost) }\end{array}$ \\
\hline Total & $\$ 334,904$ & \\
\hline
\end{tabular}

Increased O\&M cost is estimated at $\$ 8,750 / y r$.

The soot chaser is operated onca an hour for proper operation of the heat recovery unit.

\section{Analysis Results}

The results of the analysis of this ERO are shown in Table 6.17.

Table 6.17. Peak Shaving With Jacket And Exhaust Waste Heat Cogeneration

Existing chiller use

\begin{tabular}{|l|l|l|l|}
\hline \multicolumn{2}{|c|}{ Existing Condition } & \multicolumn{2}{|c|}{ Annual Energy Consumption } \\
\hline $\begin{array}{l}\text { Item } \\
\text { No. }\end{array}$ & Chiller Cooling Area & $\begin{array}{l}\text { Energy } \\
(\mathrm{kWh})\end{array}$ & $\begin{array}{l}\text { Demand } \\
(\mathrm{kW} / \mathrm{yr})\end{array}$ \\
\hline
\end{tabular}

Peak shaving wijacket plus exhaust waste heat cogeneration

\begin{tabular}{|l|l|l|l|}
\hline \multicolumn{2}{|l|}{ Energy Resource Opportunity } & \multicolumn{2}{l|}{ Annual Energy Consumption } \\
\hline Item & Cooling With Waste & Energy & Demand \\
No. & Heat From Cogeneration & $(\mathrm{kWh})$ & $(\mathrm{kW} / \mathrm{yr})$ \\
\hline
\end{tabular}

1 DGMC Med Center (See Net Value Below)

\begin{tabular}{|c|c|c|c|c|c|c|c|c|c|c|}
\hline \multirow{2}{*}{\multicolumn{6}{|c|}{$\begin{array}{l}\text { Peak shaving } w / \text { jacket plus exhaust waste heat cog } \\
\text { First Year Energy and Demand Savings }\end{array}$}} & & RO & ics & \multicolumn{2}{|c|}{ Life-cycle Cost } \\
\hline & & & & & & \multicolumn{3}{|c|}{ ERO Cost } & \multicolumn{2}{|c|}{ W/O Rebate } \\
\hline $\begin{array}{l}\text { Item } \\
\text { No. }\end{array}$ & $\begin{array}{l}\text { Energy } \\
\text { (kWh) }\end{array}$ & $\begin{array}{l}\text { Demand } \\
\text { (KW) }\end{array}$ & \begin{tabular}{|} 
Energy \\
$1992 \$$
\end{tabular} & $\begin{array}{l}\text { Demand } \\
19925\end{array}$ & $\begin{array}{c}\text { Total } \\
1992 \$\end{array}$ & $\begin{array}{l}\text { First } \\
\text { Cost } \\
\$\end{array}$ & $\begin{array}{c}\text { Fuel } \\
\text { Cost } \\
5\end{array}$ & $\begin{array}{c}\text { OxM } \\
\text { Savings } \\
\$\end{array}$ & $\begin{array}{c}\text { NPV } \\
1992 \$\end{array}$ & $\begin{array}{l}\text { Value } \\
\text { Index }\end{array}$ \\
\hline 1 & $1,813,392$ & 12.348 & 92,302 & 118,541 & 210,843 & 901,4 & 87.57 & $(59,166)$ & $(247.5$ & NA \\
\hline
\end{tabular}


Similar to the other peak shaving EROs (see Sections 6.4.1, and 6.4.2), this life-cycle cost analysis includes the benefits of electricity demand reduction. The inclusion of demand benefits is done because of the relatively great contribution of demand reduction in the total savings.

\section{Recommendations}

This ERO has a negative NPV and, therefore, is not considered a life-cycle cost-effective option. Although energy and demand savings are available, the costs of installing and maintaining the additional equipment are too great to realize any net savings.

\subsubsection{Peak Shaving With Direct Or Indirect Absorption Cooling}

\section{Description}

Direct fired (natural gas) or indirect fired (steam) absorption chillers could be utilized to peak shave some of the current electric centrifugal chiller capacity. The absorption chiller would reduce demand and electrical energy use during the six-month peak summer period. Based on the data found in the chiller operating logs, an absorption chiller of 500 tons was determined to be appropriate. The unit would operate at its design point most of the time with part load operation down to $80 \%$ during early May and late October.

\section{Data and Assumptions}

Based on manufacturers' information, the existing medical center chillers are estimated to operate at $0.775 \mathrm{~kW} /$ ton. Similarly, a direct-fired absorption chiller is expected to use $12 \mathrm{ft}^{3}$ of natural gas per hour for each ton of cooling capacity. An indirect-fired unit is expected to consume $10 \mathrm{lb}$ of steam per hour for each cooling ton. The absorption unit is expected to run the same $889 \mathrm{~h}$ as represented in the other peak shaving opportunities. Natural gas fuel costs are applied at a blended rate of $\$ 0.276 /$ therm based on current 1992 rates.

Based on these assumptions, the savings from reduced operation of the existing electric centrifugal chiller are estimated as follows:

- energy savings $=344,488 \mathrm{kWh} / \mathrm{yr}$

- demand savings $=388 \mathrm{~kW}$ (or $2,328 \mathrm{~kW} /$ mo over the six-month peak period).

The salvage value of the centrifugal chiller based on industry quotes is estimated at $\$ 12,000$ on a consignment basis. For the direct-fired replacement unit, the natural gas cost is as follows

- at $12 \mathrm{ft}^{3} /$ hoton and natural gas cost of $\$ 0.276 /$ therm 
- consumption $=6,000 \mathrm{ft}^{3} / \mathrm{h}=60$ therm $/ \mathrm{h}(6 \mathrm{MBtu} / \mathrm{h})=53,340$ therm $/ \mathrm{yr}$

- fuel cost $=\$ 14,722 / y r$

Because BAAQMD emission requirements are exempt for natural gas-fired units under $10 \mathrm{MBtu} / \mathrm{h}$, there are no additional constraints on the operation of this unit.

For the indirect-fired unit, the steam cost is as follows:

- at $10 \mathrm{lb} / \mathrm{h} \cdot$ ton and $1100 \mathrm{Btu} / \mathrm{lb}$ of steam:

- consumption $=5000 \mathrm{lb} / \mathrm{h}$

- required steam $=5000 \times 1100=5.5 \mathrm{MBtu} / \mathrm{h}$.

- at relatively new boiler efficiency of $82 \%$ and allowing for $5 \%$ system losses, the fuel (natural gas) by the existing boiler is

- natural gas rate of consumption for boilers = $5.5 / 0.78=7.051 \mathrm{MBtu} / \mathrm{h}=70.5$ therm $/ \mathrm{h}$

- total natural gas used $=$

$70.5 \times 889=62,686$ therm/yr.

- at $\$ 0.276 /$ therm:

- fuel cost $=\$ 17,301 / y r$

For the direct-fired unit, the installation cost estimate is as follows:

\begin{tabular}{|c|c|}
\hline Material & $\$ 326,911$ \\
\hline Labor & $\$ 89,444$ \\
\hline Engineering design & $\$ 32,691$ \\
\hline Shipping & $\frac{\$ 4.000}{\$ 452.046}$ \\
\hline
\end{tabular}

Increased O\&M costs over the electric chiller are estimated at $\$ 4375 / y r$ based on labor and supplies needed for routine maintenance of direct-fired absorption chiller systems. For the indirect-fired unit, the installation costs are estimated at

\begin{tabular}{lr} 
Material & $\mathbf{\$ 3 3 2 , 2 9 3}$ \\
Labor & $\$ 94,333$ \\
Engineering design & $\$ 33,229$ \\
Shipping & $\$ \mathbf{\$ 4 , 0 0 0}$ \\
\hline \multicolumn{1}{|c|}{ Total } & $\$ 462,855$
\end{tabular}


Increased O\&M costs over the electric chiller are also estimated at $\$ 4375 / \mathrm{yr}$ based on labor and supplies needed for routine maintenance of indirect-fired absorption chiller systems.

\section{Analysis Results}

The results of the analysis of this ERO are shown in Table 6.18. Similar to the other peak shaving EROs this, life-cycle cost analysis includes the benefits of electricity demand reduction. This is done because of the relatively important contribution of demand reduction in the total savings.

\section{Recommendations}

The NPV for both absorption unit options for peak shaving are negative values and, therefore, are not considered viable EROs. Although energy and demand savings are available, the initial costs of installing the absorption units coupled with the corresponding fuel costs are too great to realize any net savings.

Table 6.18. Electricity Savings With Direct Or Indirect Absorption Cooling

Existing chiller use

\begin{tabular}{|l|l|l|l|}
\hline \multicolumn{2}{|c|}{ Existing Condition } & \multicolumn{2}{|c|}{ Annual Energy Consumption } \\
\hline $\begin{array}{l}\text { Item } \\
\text { No. }\end{array}$ & Chiller Cooling Area & $\begin{array}{l}\text { Energy } \\
(\mathrm{kWh})\end{array}$ & $\begin{array}{l}\text { Demand } \\
(\mathrm{kW} / \mathrm{yr})\end{array}$ \\
\hline
\end{tabular}

1 DGMC Med Center (See Net Savings Below)

Cooling with direct or indirect absorption units

\begin{tabular}{|l|l|l|l|}
\hline \multicolumn{2}{|l|}{ Energy Resource Opportunity } & \multicolumn{2}{|l|}{ Annual Energy Consumption } \\
\hline $\begin{array}{l}\text { Item } \\
\text { No. }\end{array}$ & $\begin{array}{l}\text { Cooling With } \\
\text { Absorption Technology }\end{array}$ & $\begin{array}{l}\text { Energy } \\
\text { (kWh) }\end{array}$ & $\begin{array}{l}\text { Demand } \\
\text { (kW/yr) }\end{array}$ \\
\hline la & Direct Fired Unit & (See Net Savings Below) \\
lb. Indirect Fired Unit & (See Net Savings Below)
\end{tabular}

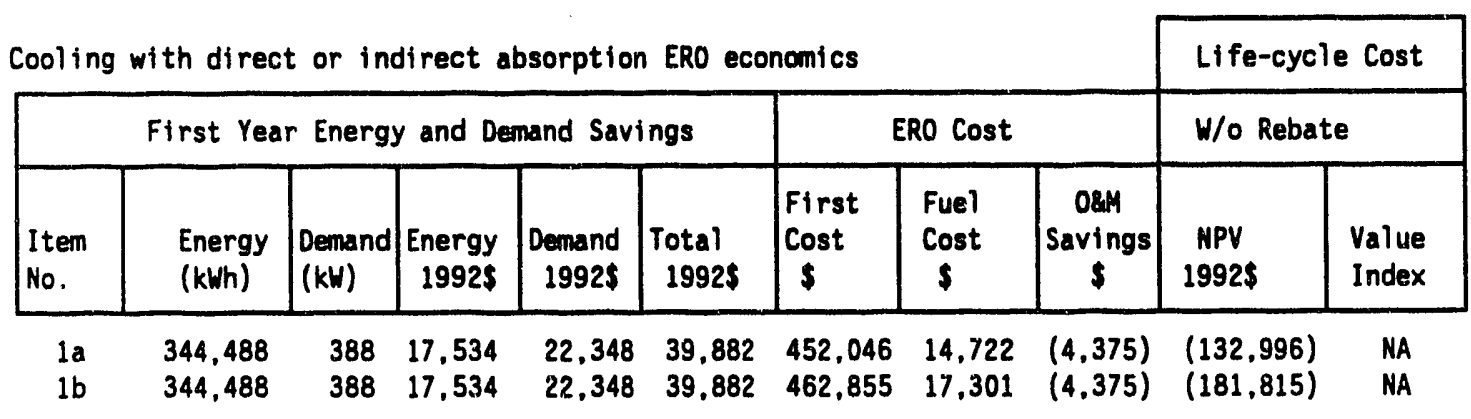




\subsubsection{Emergency Generator Fuel Switching}

\section{Description}

The increased use of the emergency generators for peak shaving might make fuel switching from fuel oil to natural gas an attractive option. Fuel switching can be accomplished with the conversion of the existing generators to dual fuel or gas only, or the complete replacement with new natural gas units. According to the manufacturer (Cummins) of the existing generators, the engines are not convertible to natural gas at the present time. The manufacturer has started research and development work on its K-19 engine, which can be fueled by natural gas, but there are no current plans to develop gas conversion for the existing KTA 38-G1 engines in use at DGMC. New natural gas units would need to be installed to replace the existing generators for this ERO option.

\section{Data and Assumptions}

The estimated cost of a new natural gas $600-\mathbf{k W}$ generator is $\$ 275,000$ with associated installation labor of $\$ 13,500 /$ unit for a total of $\$ 1,731,000$ for the site. The yearly operating hours subject to the utility peak conditions total $889 \mathrm{~h} / \mathrm{yr}$ as stated in Section 6.4.1. Similarly, the savings from operation of three units is

- energy savings $=1,600,200 \mathrm{kWh} / \mathrm{yr}$

- demand savings $=1,800 \mathrm{~kW}$.

The total estimated cost of the switch materials, equipment, and labor necessary to effect the efficient tie-in of the generators to the hospital power supplies is $\$ 10,000$.

Because the planned operation of the emergency generators exceeds $100 \mathrm{~h} / \mathrm{yr}$ and is to be used for purposes other than emergency generation, the BAAQMD requirements for emissions go into effect. Natural gas generator operation will reduce $\mathrm{NO}_{\mathbf{x}}$ emissions an estimated $40 \%$ compared to diesel fuel, but will still require control. The control requirements discussed in Section 6.4.1 apply here and require the installation of similar equipment. Estimated costs for this control are about $\$ 67,000 /$ unit or $\$ 402,000$ total. Removal costs for the six existing diesel generators is estimated at $\$ 200,000$ based on industry quotes. A salvage value of each of the existing units is also estimated from industry quotes at $\$ 12,000$ /unit on a consignment basis for a total of $\$ 72,000$. The total implementation cost for this ERO, including equipment, labor, mitigation, removal, salvage, and service tie-in, is $\$ 2,271,000$.

The natural gas cost to operate the emergency generators for peak shaving is as follows:

- The natural gas units have a standard operation rate of $111,156 \mathrm{Btu} / \mathrm{min}$ or 66.7 therm/h-unit. At 889 hours of operation and three units running, the total yearly consumption is 177,889 therm for a total cost of $\$ 49,097$ (at $\$ 0.276 /$ therm). A small diesel fuel savings also occurs for the $32-$ 
hour generator "checkout" use. This amounts to $2,124 \mathrm{gal} / \mathrm{yr}$ (see Section 6.1.4) or $\$ 1,614$. Therefore, the actual net fuel cost is $\$ 47,483$.

Operation and maintenance costs will increase because of additional generator operating hours and care of emissions mitigation equipment. Estimated changes in O\&M costs are as follows:

- Generator operator costs are considered to be the same $\$ 21,435 / \mathrm{yr}$ as derived in Section 6.4 .1

- The increase in generator maintenance cost is estimated to be approximately half of the value derived in Section 6.4 .1 , or $\$ 1,287 / \mathrm{yr}$. Emissions mitigation equipment maintenance is estimated to remain at the $\$ 6,480 / y r$ value derived in Section 6.4.1. As with the other peak shaving EROs, the $\$ 11,016 / y r$ utility standby service charge would be in effect.

- Total maintenance cost increase equals $\$ 40,218 / y r$, including the standby charge.

\section{Analysis Results}

The results of the analysis of this ERO are shown in Table 6.19.

Table 6.19. Peak Shaving With Natural Gas Emergency Generators

Existing electricity use

\begin{tabular}{|l|l|l|l|}
\hline \multicolumn{2}{|c|}{ Existing Condition } & \multicolumn{2}{|c|}{ Annual Energy Consumption } \\
\hline $\begin{array}{l}\text { Item } \\
\text { No. }\end{array}$ & Energy Use Area & $\begin{array}{l}\text { Energy } \\
(\mathrm{kWh})\end{array}$ & $\begin{array}{l}\text { Demand } \\
(\mathrm{kW} / \mathrm{yr})\end{array}$ \\
\hline 1 & DGMC Med Center & $22,946,000$ & 24,311
\end{tabular}

Electricity use with peak shaving

\begin{tabular}{|l|l|l|l|}
\hline \multicolumn{2}{|l|}{ Energy Resource Opportunity } & \multicolumn{2}{|l|}{ Annual Energy Consumption } \\
\hline $\begin{array}{l}\text { Item } \\
\text { No. }\end{array}$ & $\begin{array}{l}\text { Energy Use Area } \\
\text { W/Peak Shaving }\end{array}$ & $\begin{array}{l}\text { Energy } \\
(\mathrm{kWh})\end{array}$ & $\begin{array}{l}\text { Demand } \\
(\mathrm{kW} / \mathrm{yr})\end{array}$ \\
\hline 1 & DGMC Med Center & $21,345,800$ & 13,511
\end{tabular}

\begin{tabular}{|c|c|c|c|c|c|c|c|c|c|c|}
\hline \multicolumn{9}{|c|}{ Electricity use with peak shaving ERO economics } & \multicolumn{2}{|c|}{ Life-cycle Cost } \\
\hline \multicolumn{6}{|c|}{ First Year Energy and Demand Savings } & \multicolumn{3}{|c|}{ ERO Cost } & \multicolumn{2}{|c|}{ W/o Rebate } \\
\hline $\begin{array}{l}\text { Item } \\
\text { No. }\end{array}$ & $\begin{array}{l}\text { Energy } \\
(\mathrm{kWh})\end{array}$ & $\left|\begin{array}{l}\text { Demand } \\
(\mathrm{kW})\end{array}\right|$ & $\begin{array}{r}\text { Energy } \\
1992 \$\end{array}$ & $\begin{array}{l}\text { Demand } \\
1992 \$\end{array}$ & $\begin{array}{c}\text { Total } \\
1992 \$\end{array}$ & $\begin{array}{l}\text { First } \\
\text { Cost } \\
\$\end{array}$ & $\begin{array}{c}\text { Fuel } \\
\text { Cost } \\
\$\end{array}$ & $\begin{array}{c}\text { O\&N } \\
\text { Savings } \\
\$\end{array}$ & $\begin{array}{l}\text { NPV } \\
1992 \$\end{array}$ & $\begin{array}{l}\text { Value } \\
\text { Index }\end{array}$ \\
\hline
\end{tabular}


Similar to other demand-reduction EROs, this life-cycle cost analysis does include the benefits of electricity demand reduction. This is because of the relatively large contribution of demand reduction in the total savings. Unlike other EROs, demand reduction is the primary source of savings.

\section{Budget Information}

The total first cost of this ERO would be $\$ 2,271,000$ for the new generators, emissions control equipment, removal and salvage, and hospital electrical supply tie-in.

\section{Operation and Maintenance Impacts}

The cost of O\&M would be expected to increase by $\$ 40,218 / y r$ for operator time and increased labor and materials for routine maintenance on the units in use and for associated emissions mitigation.

\section{Energy, Demand, and Cost Savings}

Energy reduction as a result of the peak shaving use of the generators is estimated at $1,600,200$ $\mathrm{kWh}$ at a cost savings of $\$ 81,450$. Peak shaving demand savings would be expected to be 1,800 $\mathrm{kW} / \mathrm{mo}$ in the summer for a savings of $\$ 103,680$, Total yearly savings are expected to be $\$ 185,130$.

\section{Recommendations}

This ERO has a large negative NPV and, therefore, is not considered a cost-effective option. As with other peak shaving options, large energy and cost savings could be achieved with this option. The capital and maintenance costs are too high, however, to offset these savings.

\subsection{Electric Rate Structure Resource Opportunity}

\section{Description}

The hospital currently uses two electric power sources (primary and transmission service voltages). It aiso has six emergency generators available $(3,600 \mathrm{~kW}$ electrical capacity) in the event of PG\&E power outages. The overall electric rate paid by the medical center can be reduced by electing to receive nonfirm service under Schedule E-20. The use of the emergency generators, as specified by PG\&E, will qualify for the nonfirm service at a reduced cost from that currently paid. There is no actual energy or demand reduction associated with this option. Cost reduction for energy consumption is achieved, however, by restructuring the applicable electricity rate schedule.

Under the E-20 program, the hospital may be required to reduce demand to a designated number of kilowatts, referred to as the hospital's contractual "firm service level." PG\&E will make requests for such curtailments from its non firm service customers when, in PG\&E's sole judgment, a 
system-wide or local operating condition exists that will impair the ability of PG\&E to meet the demands of its other customers.

To qualify for nonfirm service, the customer must have had an average peak-period demand of at least $500 \mathrm{~kW}$ during each of the last six summer billing months prior to the customer's application for nonfirm service. The frequency of activation of the curtailment is up to 30 times a year with 30 minutes notification. A maximum of $6 \mathrm{~h} / \mathrm{d}$ operation with a cumulative operating time of $100 \mathrm{~h} / \mathrm{yr}$ are the limits for emergency generator operation.

\section{Data and Assumptions}

With the assistance of Mr. Richard Horsma of PG\&E, average blended rates (demand charges included) for both firm and nonfirm (curtailable) rates were obtained. The blended rate values provided by Mr. Horsma for the "transmission" and "primary" portions of the March 1991 through February 1992 billing period (see Section 3.1.2) were combined to obtain a total service rate. The average blended firm rate based on current usage was calculated at $\$ 0.0757 / \mathrm{kWh}$, and the corresponding curtailable rate was calculated at $\$ 0.0697 / \mathrm{kWh}$ based on a $1,000-\mathrm{kW}$ firm service level. At this $1,000-\mathrm{kW}$ level, the medical center would be required (during curtailment) to provide all of its own capacity above $1,000 \mathrm{~kW}$.

This analysis is completed on the assumption that all other EROs (including only the highest kilowatthour saving of the mutually exclusive EROs) are incorporated. This provides a conservative consumption value for assessment of potential savings from a curtailable rate. There are no costs involved with this resource opportunity. From the first electricity demand-reduction ERO (see Section 6.4.1), it can be seen that the fuel cost of operating the emergency generators is only slightly more than the electric kilowatthour savings alone. In subsequent electricity demand options, the fuel cost is less than the kilowatthour savings. For this analysis, the savings and fuel costs are considered to be equal.

Coordination would be required with PG\&E to set up and participate in this program. The operation of the emergency generators would be similar to the present weekly check-out tests, with PG\&E notifying the medical center when and how long to operate the emergency generators at times of curtailment.

\section{Energy and Cost Savings}

The electrical energy use after incorporation of the EROs would be $16,869,639 \mathrm{kWh} / \mathrm{yr}$. At $\$ 0.0757 / \mathrm{kWh}$, the annual total cost (including demand) would be $\$ 1,277,032 / \mathrm{yr}$. At $\$ 0.0697 / \mathrm{kWh}$, the annual cost would be $\$ 1,175,814$.

The dollar savings per year would be $\$ 101,218$. There are no actual energy savings and no appreciable costs. 


\section{Recommendations}

Because of its minimal administration cost and high potential dollar savings, this ERO should be considered regardless of its lack of energy impact. At a current high monthly demand of around 4500 $\mathrm{kW}$, the combination of the $1000 \mathrm{~kW}$ firm service level plus the six emergency generator output of $3600 \mathrm{~kW}$ (total $4600 \mathrm{~kW}$ ) should be able to handle the hospital load. Because this situation would leave minimal reserve capacity $(<100 \mathrm{~kW}$ ), a higher firm service level may be required. The emissions requirements imposed by the air quality board would not be in effect because the program limits generator operation to $100 \mathrm{~h} / \mathrm{yr}$. By selecting the nonfirm service program, the backup emergency generators would, in effect, be allocated to the nonfirm program, and any other use, such as peak shaving, would not by possible. This means that this ERO option is mutually exclusive with respect to the five peak shaving options analyzed in Sections 6.4.1, 6.4.2, 6.4.3, 6.4.4, and 6.4.5.

\subsection{Natural Gas Supply Source Resource Opportunity}

\section{Description}

An option to using utility-supplied natural gas is the purchase of natural gas at a wellhead that is subsequently transported through existing utility lines at a specified utility transport fee. Savings could be achieved in natural gas costs if a favorable supply is available to the site that is substantially less costly than the supplies used by the utility.

\section{Data and Assumptions}

Natural gas is currently supplied to the medical center at approximately $\$ 0.284 /$ therm. Current utility gas transportation rates for customer supplied gas are \$0.12016 (summer)/therm and \$0.13724 (winter)/therm. Current spot market gas prices range from $\$ 0.209$ to $\$ 0.288 /$ therm. The combination of spot gas at its lowest offering and the lowest utility transportation rate produces an equivalent wellhead gas rate of $\$ 0.329 /$ therm.

\section{Recommendations}

There appears to be no advantage to seeking a wellhead gas rate purchase for the purpose of cost reduction. Currently, the cost would be higher than that obtainable from the local utility. 


\subsection{Energy-Related Issues}

This section contains a discussion of issues pertaining to the medical center that are not specifically analyzable EROs. Each of these issues can have a potential effect on energy use or cost savings and, therefore, are included here.

\subsection{Chiller Heat Recovery}

The current heat recovery system applied to primary chillers $\# 1$ and $\# 2$ located in the plant building is a sound, efficient system that is designed to supplement both the domestic hot water and terminal space reheat systems throughout the hospital facility. Recently, the system was unable to provide recovered heat. Apparently, the cause was poor chiller performance, which caused deactivation of the system. As of the writing of this report, a solution to the problem is believed to have been found by the site staff and site support engineers. The heat recovery system relies on a temperature-driven control that regulates the supply of chiller fluid that is routed away from the cooling tower system into the heat recovery loop. If this control is not functioning, it is believed that the immediate fluid flow through the heat recovery loop is not of sufficient thermal capacity to be effective and, in turn, derates chiller performance because of low fluid flows. When the system is again functioning as designed, it is unlikely that any cost-effective improvements or changes would exist to improve the efficiency of the system.

\subsection{Energy Management Control System}

The existing energy management and control system (EMCS) is a Honeywell Delta 5600 system. The central computer unit is located in the master control room in Building 877 of Travis Air Force Base. Presently, the EMCS control and monitoring for DGMC is located in a second floor room of the main hospital (Building 777). A limited monitoring station is also located in the energy plant (Building 779).

Currently, the existing system encompasses all of the control capability that can reasonably be used at the hospital. Some of the available control capability is unused because of specific hospital operations and environment control requirements. A new EMCS system would not significantly improve any control functions that would reduce energy because the current system performs well in those areas. However, as the existing system continues to age, replacement parts and maintenance will continue to increase in cost and availability. Eventually, it may be cost effective from a maintenance cost perspective to replace the primary processing portions of the system with a more compact and reduced maintenance module, resulting in the removal of the hospital EMCS system from the Travis site-wide system. The replacement system would probably be a personal-computer based system that could utilize all of the existing control and monitoring equipment already in place. This would be more cost-effective and less complex than attempting to update and bring on line the existing Delta 5600 system. 
Information on heating and cooling load requirements for the hospital is currently relayed by telephone to the plant operators from the main hospital control and monitoring staff. In some cases, this relay can cause lags in supply of needed heating or cooling capacity because of lead times required by the plant equipment. If the plant personnel were able to also monitor hospital equipment loading and operation, more consistent heating and cooling might be achieved. While this is not a specific ERO, it may have a definite effect on patient comfort. 


\subsection{Summary of ERO Options}

A summary of all cost-effective proposed EROs ranked by their value index is shown in Table 8.1. This table includes the primary characteristics, energy consumption, cost, NPV (difference in life-cycle cost of present and proposed options), value index (NPV divided by installation cost), and savings to investment ratio (SIR), also known as return on investment (ROI), for each ERO. The options not shown in the table are those that were found not life-cycle cost-effective EROs.

Each of the EROs represented in the table are independent of each other, except for the two costeffective peak shaving and waste heat recovery cogeneration options, and the nonfirm rate option (single asterisked items - "*n). These items are exclusive of each other because they represent either versions of a similar peak shaving option or rate structure changes that would preclude peak shaving. They are all represented in Table 8.1 because they all provide valid choices for large energy consumption, demand, and/or billing rate reductions. When faced with limited funding or other constraints, one of the options may prove to be more appropriate than the others without regard to maximum savings potential or present value. The totals at the bottom of Table 8.1 are for all independent EROs and include only the value for the mutually exclusive option with the highest yearly energy savings value (see Section 6.4.2). The "total net (\$)" savings value for the peak shaving/cogeneration options includes the loss in cost savings because of the increased oil use.

Table 8.1. DGMC ERO Summary and Ranking by Value Index

\begin{tabular}{|c|c|c|c|c|c|c|c|c|c|c|}
\hline \multirow[b]{2}{*}{$\begin{array}{l}\text { Report } \\
\text { Section }\end{array}$} & \multirow[b]{2}{*}{$\begin{array}{c}\text { ERO } \\
\text { Description }\end{array}$} & \multirow[b]{2}{*}{$\begin{array}{l}\text { First } \\
\text { Cost }(\$)\end{array}$} & \multicolumn{5}{|c|}{ Yearly Energy Savings } & \multirow[b]{2}{*}{ NPV } & \multirow[b]{2}{*}{$\begin{array}{l}\text { Value } \\
\text { Index }\end{array}$} & \multirow[b]{2}{*}{$\begin{array}{c}\text { SIR } \\
\text { (ROI) }\end{array}$} \\
\hline & & & kWh & $\begin{array}{c}\mathrm{kH} \\
\text { (year) }\end{array}$ & $\begin{array}{c}\text { Gas } \\
\text { (kcf) }\end{array}$ & $\begin{array}{c}011 \\
(g a 1)\end{array}$ & $\begin{array}{c}\text { Total } \\
\text { Net }(\$)\end{array}$ & & & \\
\hline $6.5 \star$ & Non-firm rate change & 0 & 0 & 0 & 0 & & 101,218 & NA & NA & NA \\
\hline 6.3 .1 & Bofler oxygen reset & 0 & 0 & 0 & 1,032 & 0 & 2,936 & 55,313 & NA & NA \\
\hline 6.1 .7 & Refrigeration light timers & 632 & 37.778 & NA & 0 & 0 & 1.923 & 27.400 & 43.40 & 44.35 \\
\hline 6.1 .5 & Incandescent upgrade & 2,051 & 57.494 & 102 & 0 & 0 & 3,447 & 51.609 & 25.20 & NA \\
\hline 6.1 .6 & Light intensity decrease & 438 & 23,829 & 22 & 0 & 0 & 1.033 & 10.712 & 24.50 & 25.46 \\
\hline 6.1 .8 & Daylight control (Fluor.) & 3,815 & 23,884 & 55 & 0 & 0 & 1,497 & 16,447 & 4.30 & 5.31 \\
\hline 6.2 .1 & ASD fan control & 283,371 & 2.272 .564 & NA & 0 & 0 & 104,608 & $1,243,049$ & 3.78 & 5.4 \\
\hline 6.3 .2 & Air curtain & 1.254 & 5,508 & 0 & 18 & 0 & 331 & 3,811 & 3.04 & 4.04 \\
\hline 6.1 .3 & 4-tube fluor. upgrade & 50.952 & 163,652 & 309 & 0 & 0 & 9,909 & 106,826 & 2.10 & NA \\
\hline 6.1 .8 & Daylight control (MH) & 6.804 & 15,186 & 35 & 0 & 0 & 950 & 11,389 & 1.70 & 4.81 \\
\hline 6.1 .3 & 3-tube fluor. upgrade & 99,682 & 209,176 & 365 & 0 & 0 & 12,512 & 118,397 & 1.19 & 8.07 \\
\hline 6.1 .3 & 2-tube fluor. upgrade & 445,543 & 902,103 & 1,592 & 0 & 0 & 54,043 & 389,500 & 0.87 & 2.99 \\
\hline 6.1 .3 & 6-tube fluor. upgrade & 54,171 & 96,458 & 135 & 0 & 0 & 5,601 & 36,477 & 0.67 & 2.74 \\
\hline 6.1 .3 & 1-tube fluor. upgrade & 407.222 & 515,538 & 650 & 0 & 0 & 29.559 & 209,993 & 0.52 & 2.69 \\
\hline $6.4 .1 *$ & Peak shave $w / g e n e r a t o r s$ & 112,000 & 1.600 .200 & 10.800 & 0 & $(115,224)$ & 97.560 & 124,360 & 0.30 & 1.28 \\
\hline 6.1 .4 & Exit sign upgrade & 11,534 & 15,791 & 16 & 0 & 0 & 885 & 3,098 & 0.27 & 1.27 \\
\hline $6.4 .2 \star$ & Peak shave w/jacket cogen & 566,531 & $1.737,400$ & 11.796 & 0 & $(115,224)$ & 114,106 & 81,200 & 0.14 & 1.13 \\
\hline & TOTALS * & $1.934,000$ & $6,07.6,361$ & 15.077 & 1,050 & $(115,224)$ & 343,340 & $2,365,221$ & & \\
\hline
\end{tabular}


The NPV for the nonfirm rate change option (see Section 6.5) is undefined and considered to be infinite because the option has virtually no first cost. The value indexes for the ASD fan control and EE motor upgrade EROs are averages over the list of fans and motors represented. The nonfirm rate change ERO (see Section 6.5) and boiler oxygen reset ERO (see Section 6.3.1) have undefined value indexes that are considered to be infinite for purposes of this analysis. This is because the first cost value is virtually zero for both of these options. These items are ranked at the top of all EROs because they are near no-cost EROs with large energy savings. The nonfirm rate change ERO (see Section 6.5), boiler oxygen reset ERO (see Section 6.3.1), incandescent upgrade (see Section 6.1.5), and four-tube fluorescent upgrade (see Section 6.1.3) have undefined SIRs, which are also considered to be infinite in this analysis. This is because of either a zero first cost or the offset of first costs by the value of the O\&M savings. In effect, the O\&M savings are considered to produce a net cash flow so there is no net first cost over the life of the measure. The nonfirm rate ERO is unusual in that it has a large cost saving impact, but no energy-saving impact.

The implementation of all EROs could result in a yearly electricity savings of more than 6000 MWh, or $26 \%$ of current yearly electricity consumption. More than $15 \mathrm{MW}$ of billable load (total megawatt billed by the utility for a 12-month period), or more than $34 \%$ of current billed demand, could also be saved. Corresponding natural gas savings would be $1050 \mathrm{kcf}$ (just over $1 \%$ of the current consumption). Total yearly net energy cost savings for all options would be $>\$ 343,340$. This value could be considered a conservative estimate of overall cost savings since it does not included any O\&M savings for all of the nonpeak shaving options. A yearly increase in fuel oil use of $115,224 \mathrm{gal}$ would be required to achieve this savings, as well as installation costs of approximately $\$ 2.3 \mathrm{M}$.

For comparison, the EROs are presented in Tables 8.2, 8.3, and 8.4 with different ranking criteria. Table 8.2 shows the EROs ranked by NPV without regard to VI. This table indicates those items with the greatest overall cost savings potential with respect to both energy and maintenance costs. Again, all three mutually exclusive options are included for comparison. The nonfirm rate change option is included at the top of the table since its NPV is considered to be infinite.

Table 8.3 shows the EROs ranked by potential total yearly energy savings (kilowatthour plus natural gas savings on a MBtu basis). Like the two previous tables, the mutually exclusive options are included. It is important to remember when reviewing this table that the kilowatthour savings represented for the two peak shaving options is more than offset by the increased fuel oil use. In this respect, the kilowatthour saving values for the peak shaving options should be considered nonexistent compared to all other EROs. Table 8.4 shows the EROs ranked by "first cost." As with the other tables, the mutually exclusive options are included. 
Table 8.2. DGMC ERO Summary and Ranking by Net Present Value

\begin{tabular}{|c|c|c|c|c|c|c|c|c|c|c|}
\hline \multirow[b]{2}{*}{$\begin{array}{l}\text { Report } \\
\text { Section }\end{array}$} & \multirow[b]{2}{*}{$\begin{array}{c}\text { ERO } \\
\text { Description }\end{array}$} & \multirow[b]{2}{*}{$\begin{array}{l}\text { Ftrst } \\
\text { Cost (\$) }\end{array}$} & \multicolumn{5}{|c|}{ Yearly Energy Savings } & \multirow[b]{2}{*}{ NPV } & \multirow[b]{2}{*}{$\begin{array}{l}\text { Value } \\
\text { Index }\end{array}$} & \multirow[b]{2}{*}{$\begin{array}{c}\text { SIR } \\
\text { (ROI) }\end{array}$} \\
\hline & & & kWh & $\begin{array}{c}k W \\
\text { (year) }\end{array}$ & $\begin{array}{c}\text { Gas } \\
(k c f)\end{array}$ & $\begin{array}{c}011 \\
(g a 1)\end{array}$ & $\begin{array}{c}\text { Total } \\
\text { Net }(\$)\end{array}$ & & & \\
\hline $6.5 \star$ & Non-firm rate change & 0 & 0 & 0 & 0 & 0 & 101.218 & NA & NA & NA \\
\hline 6.2 .1 & ASD fan control & 283.371 & $2,272.564$ & NA & 0 & 0 & 104,608 & $1,243,049$ & 3.78 & 5.4 \\
\hline 6.1 .3 & 2-tube fluor. upgrade & 445,543 & 902.103 & 1,592 & 0 & 0 & 54,043 & 389,500 & 0.87 & 2.99 \\
\hline 6.1 .3 & 1-tube fluor. upgrade & 407.222 & 515,538 & 650 & 0 & 0 & 29.559 & 209.993 & 0.52 & 2.69 \\
\hline $6.4 .1 *$ & Peak shave w/generators & 412,000 & 1.600 .200 & 10,800 & 0 & $(115,224)$ & 97,560 & 124.360 & 0.30 & 1.28 \\
\hline 6.1 .3 & 3-tube fluor. upgrade & 99,682 & 209,176 & 365 & 0 & 0 & 12,512 & 118,397 & 1.19 & 8.07 \\
\hline 6.1 .3 & 4-tube fluor. upgrade & 50.952 & 163.652 & 309 & 0 & 0 & $0 \quad 9.909$ & 106,826 & 2.10 & NA \\
\hline 6.4 .2 * & Peak shave w/ Jacket cogen & 566.531 & $1,737,400$ & 11.796 & 0 & $(115,224)$ & 114,106 & 81,200 & 0.14 & 1.13 \\
\hline 6.3 .1 & Boiler oxygen reset & & & 0 & 1.032 & 0 & $0 \quad 2,936$ & 55,313 & NA & NA \\
\hline 6.1 .5 & Incandescent upgrade & 2.051 & 57.494 & 102 & 0 & 0 & 3,447 & 51.609 & 25.20 & NA \\
\hline 6.1 .3 & 6-tube fluor. upgrade & 54,171 & 96,458 & 135 & 0 & & 5,601 & 36,477 & 0.67 & 2.74 \\
\hline 6.1 .7 & Refrigeration light timers & 632 & 37.778 & NA & 0 & 0 & 1,923 & 27.400 & 43.40 & 44.35 \\
\hline 6.1 .8 & Daylight control (Fluor) & 3,815 & 23.884 & 55 & 0 & 0 & 1.497 & 16,447 & 4.30 & 5.31 \\
\hline 6.1 .8 & Daylight control (MH) & 6.804 & 15,186 & 35 & 0 & 0 & 950 & 11.389 & 1.70 & 4.81 \\
\hline 6.1 .6 & Light intensity decrease & 438 & 23,829 & 22 & 0 & & 1.033 & 10.712 & 24.50 & 25.46 \\
\hline 6.3 .2 & Air curtain & 1.254 & 5,508 & 0 & 18 & & 331 & 3,811 & 3.04 & 4.04 \\
\hline 6.1 .4 & Exit sign upgrade & 11,534 & 15.791 & 16 & 0 & & 885 & 3.098 & 0.27 & 1.27 \\
\hline
\end{tabular}

TOTALS *

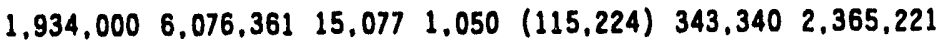

Table 8.3. DGMC ERO Summary and Ranking by Total Energy Savings

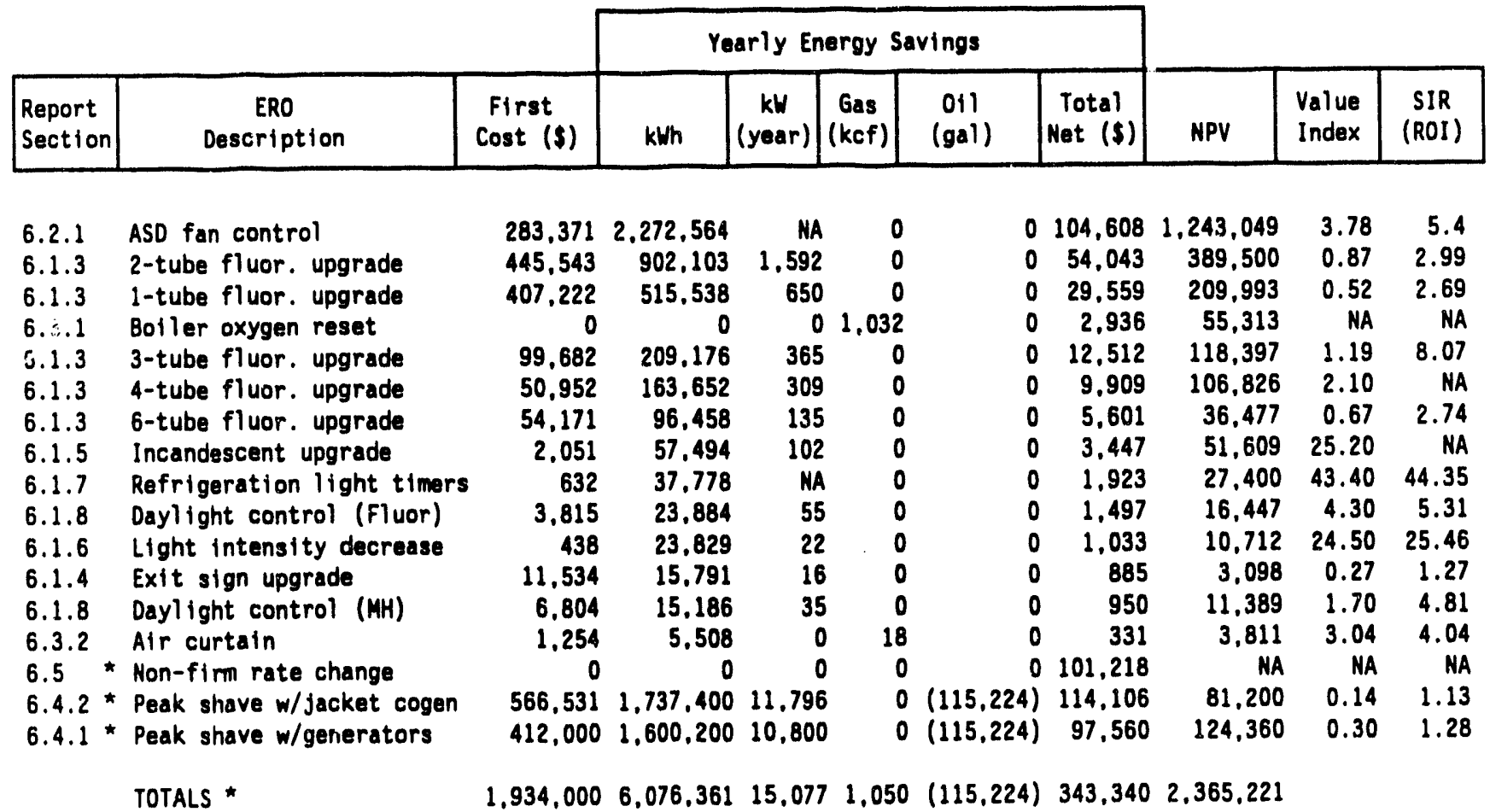


Table 8.4. DGMC ERO Summary and Ranking by First Cost

\begin{tabular}{|c|c|c|c|c|c|c|c|c|c|c|}
\hline \multirow[b]{2}{*}{$\begin{array}{l}\text { Report } \\
\text { Section }\end{array}$} & \multirow[b]{2}{*}{$\begin{array}{c}\text { ERO } \\
\text { Description }\end{array}$} & \multirow[b]{2}{*}{$\begin{array}{l}\text { First } \\
\text { Cost (\$) }\end{array}$} & \multicolumn{5}{|c|}{ Yearly Energy Savings } & \multirow[b]{2}{*}{ NPV } & \multirow[b]{2}{*}{$\begin{array}{l}\text { Value } \\
\text { Index }\end{array}$} & \multirow[b]{2}{*}{$\begin{array}{c}\text { SIR } \\
(R O I)\end{array}$} \\
\hline & & & kWh & $\begin{array}{c}k W \\
\text { (year) }\end{array}$ & $\begin{array}{c}\text { Gas } \\
(k c f)\end{array}$ & $\begin{array}{c}011 \\
(g a 1)\end{array}$ & $\begin{array}{c}\text { Total } \\
\text { Net }(\$)\end{array}$ & & & \\
\hline $6.5 \star$ & Non-firm rate change & 0 & 0 & 0 & 0 & & 0101,218 & NA & NA & NA \\
\hline 6.3 .1 & Boiler oxygen reset & 0 & 0 & & 1,032 & 0 & 2.936 & 55,313 & NA & NA \\
\hline 6.1 .6 & Light intensity decrease & 438 & 23.829 & 22 & 0 & & $0 \quad 1.033$ & 10.712 & 24.50 & 25.46 \\
\hline 6.1 .7 & Refrigeration light timers & 632 & 37,778 & $\mathrm{NA}$ & 0 & & $0 \quad 1,923$ & 27,400 & 43.40 & 44.35 \\
\hline 6.3 .2 & Air curtain & 1.254 & 5,508 & 0 & 18 & & 331 & 3,811 & 3.04 & 4.04 \\
\hline 6.1 .5 & Incandescent upgrade & 2,051 & 57,494 & 102 & 0 & & 3,447 & 51.609 & 25.20 & NA \\
\hline 6.1 .8 & Daylight control (Fluor) & 3,815 & 23.884 & 55 & 0 & & 1,497 & 16,447 & 4.30 & 5.31 \\
\hline 6.1 .8 & Daylighi :ontrol (MH) & 6,804 & 15,186 & 35 & 0 & & 950 & 11.389 & 1.70 & 4.81 \\
\hline 6.1 .4 & Exit sign ufqrade & 11.534 & 15,791 & 16 & 0 & & 885 & 3,098 & 0.27 & 1.27 \\
\hline 6.1 .3 & 4-tube fluor. upgrade & 50,952 & 163.652 & 309 & 0 & & 9,909 & 106,826 & 2.10 & NA \\
\hline 6.1 .3 & 6-tube fluor. upgrade & 54.171 & 96.458 & 135 & 0 & & 5,601 & 36,477 & 0.67 & 2.74 \\
\hline 6.1 .3 & 3-tube fluor. upgrade & 39.682 & 209,176 & 365 & 0 & & 12,512 & 118,397 & 1.19 & 8.07 \\
\hline 6.2 .1 & ASD fan control & 283.371 & 2.272 .564 & NA & 0 & & 0104,608 & 1.243 .049 & 3.78 & 5.4 \\
\hline 6.1 .3 & 1-tube fluor. upgrade & 407,222 & 515,538 & 650 & 0 & & $0 \quad 29.559$ & 209.993 & 0.52 & 2.69 \\
\hline $6.4 .1 *$ & Peak shave $w / g e n e r a t o r s$ & 412.000 & $1,600,200$ & 10.800 & 0 & $(115,224)$ & 97.560 & 124,360 & 0.30 & 1.28 \\
\hline 6.1 .3 & 2-tube fluor. upgrade & 445,543 & 902.103 & 1.592 & 0 & 0 & $0 \quad 54,043$ & 389,500 & 0.87 & 2.99 \\
\hline $6.4 .2 \star$ & Peak shave w/jacket cogen & 566,531 & 1.737 .400 & 11.796 & 0 & $(115,224)$ & 114.106 & 81.200 & 0.14 & 1.13 \\
\hline & TOTALS * & $1.934,000$ & $6,076,361$ & 15.077 & 1.050 & $(115,224)$ & 343,340 & $2,365,221$ & & \\
\hline
\end{tabular}




\subsection{References}

American Society of Heating, Refrigerating and Air-Conditioning Engineers, Inc. (ASHRAE). 1989. 1989 ASHRAE Handbook Fundamentals. Atlanta, Georgia.

American Society of Heating, Refrigerating and Air-Conditioning Engineers, Inc. (ASHRAE). 1987. 1987 ASHRAE Handbook HVAC Systems and Applications. Atlanta, Georgia.

Dirks, J. A., E. E. Richman, R. W. Schultz, and S. A. Shankle. 1992. Lighting Technology Screening Matrix (LTSM). Developed by Pacific Northwest Laboratory, Richland, Washington, July 13, 1992. Copyright 1992, Battelle Memorial Institute.

Illuminating Engineering Society of North America (IES). 1981. Mluminating Engineering Society of North America Lighting Handbook. New York.

Mendelson, C., and R. Rundquist. 1991. "The Domino Effect: Lighting/Air

Conditioning/Energy/Environment." Strategic Planning for Energy and the Environment 2(1):53-60.

Nadel, S., M. Shepard, S. Greenberg, A. T. de Almeida. 1991. Energy-Efficient Motor Systems - A Handbook on Technology, Programs, and Policy Opportunities. American Council for an Energy-Efficient Economy, Washington, D.C.

National Bureau of Standards (NBS). 1987. Life-Cycle Costing Manual for the Federal Energy Management Program. NBS Handbook 135, U.S. Government Printing Office, Washington, D.C.

National Institu'e of Standards and Technology (NIST). 1991. Energy Prices and Discount Factors for LifeCycle Cost Analysis 1992. iv ST Handbook 135, National Technical Information Service, Springfield, Virginia.

R. S. Means Company, Inc. 1991a. MEANS Electrical Cost Data: 1992 15th Annual Edition. Kingston, Massachusetts.

R. S. Means Company, Inc. 1991b. MEANS Mechanical Cost Data: 1992 15th Annual Edition. Kingston, Massachusetts.

R. S. Means Company, Inc. 1991c. MEANS Repair and Remodeling Cost Data: 1992 15th Annual Edition. Kingston, Massachusetts.

U.S. Department of Commerce. 1977. Climactic Atlas of the United States. Washington, D.C.. 
Washington State Energy Office (WSEO). 1991. Commercial Energy Auditing: Getting Organized. Olympia, Washington. 


\section{Appendix}

Analysis Details and Electricity Demand Profiles 


\section{Appendix}

\section{Analysis Details and Electricity Demand Profiles}

\section{Lighting Technology Screening Matrix}

The LTSM (Dirks et al. 1992) is a software program developed at PNL in support of the Federal Relighting Initiative. It was designed to assist federal government facilities in their efforts to comply with mandated life-cycle costing for energy equipment investments. The LTSM is a DOS-based software tool that calculates the life-cycle cost of an existing lighting fixture and of a large number of potential energy-efficient replacements. The LTSM calculates life-cycle cost based on federal lifecycle cost guidelines.

\section{Building Life-Cycle Cost Program}

The BLCC is a software tool developed by NIST for use with the NBS Handbook 135 (NBS 1987) and the NIST Handbook 135 (NIST 1991). It is designed to be used for applying the Federal Life-Cycle Cost Guidelines to analysis of proposed energy capital investments. The BLCC has been prepared as an aid to implementing life-cycle cost evaluations of potential energy conservation and renewable EROs in new and existing federal buildings. It can also be used for evaluating similar resource opportunities in the private sector.

\section{DGMC Electricity demand Profiles}

Although limited data were available to assess the demand profile of consumption for the DGMC, the information provided is useful. While metering was not within the scope of this project, some short-term electrical service monitoring was available through the local utility. These data are not a complete picture of the site's demand profile, but does indicate the kind of demand requirements present at the medical center.

None of the chiller load points or main hospital feeders were monitorable using the available equipment without requiring a temporary shutdown of hospital areas. This was considered an undesirable risk for the available data and not pursued. Four primary motor control centers to the power plant were monitored from 24 to 72 hours. The metering points included

- "Z1" cooling towers, condensate, chilled water supply, and other cooling mode equipment

- " $\mathrm{Z} 2$ " primarily cooling tower and condensate with some fuel oil and domestic water functions

- "Z3" boiler support, hot water supply and feedwater, air compressor, and some exhaust 
- "X2" primarily fuel oil supply, air drying, and emergency ventilation.

Figures A.1 through A.8 show the relative demand profile for various time periods available for metering. Please note that the metering periods were not consistent for all metering points; some started in late morning and others around midnight. For ease of comparison, the data has been fit to consistent "midnight to midnight" periods. In most cases, the cooling load beginning around 10:00 a.m. or 11:00 a.m. is very evident. 


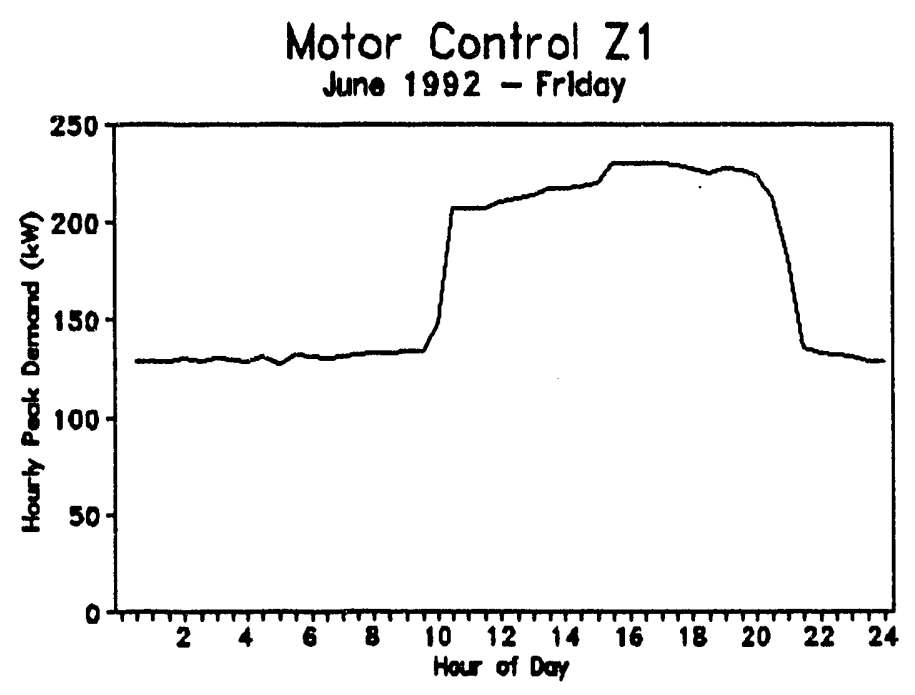

Figure A.1 "Z1" 24-Hour Electricity Demand Profile - Friday

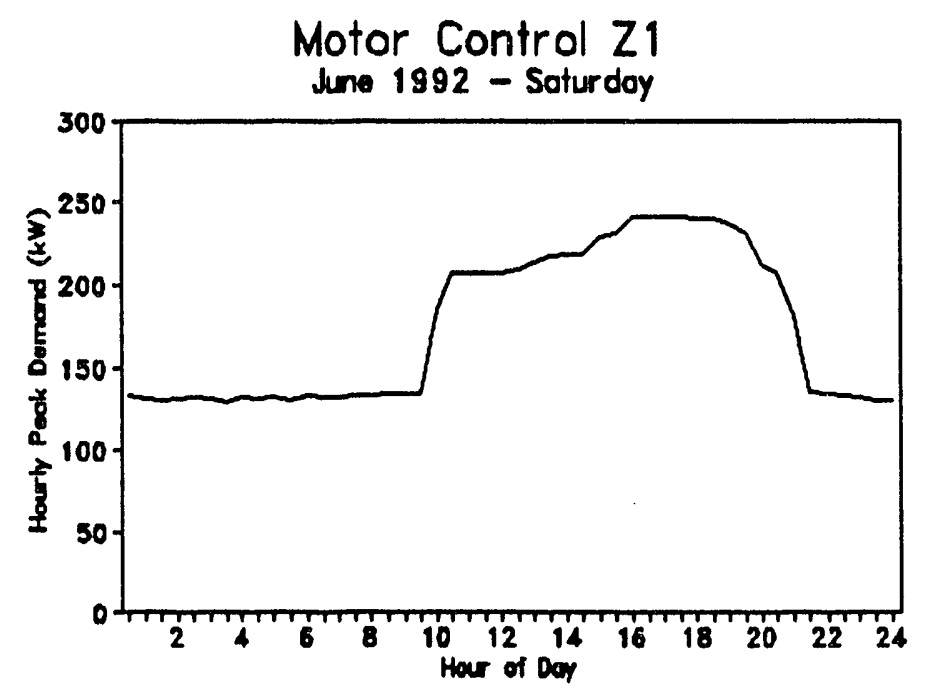

Figure A.2 "Z1" 24-Hour Electricity Demand Profile - Saturday 


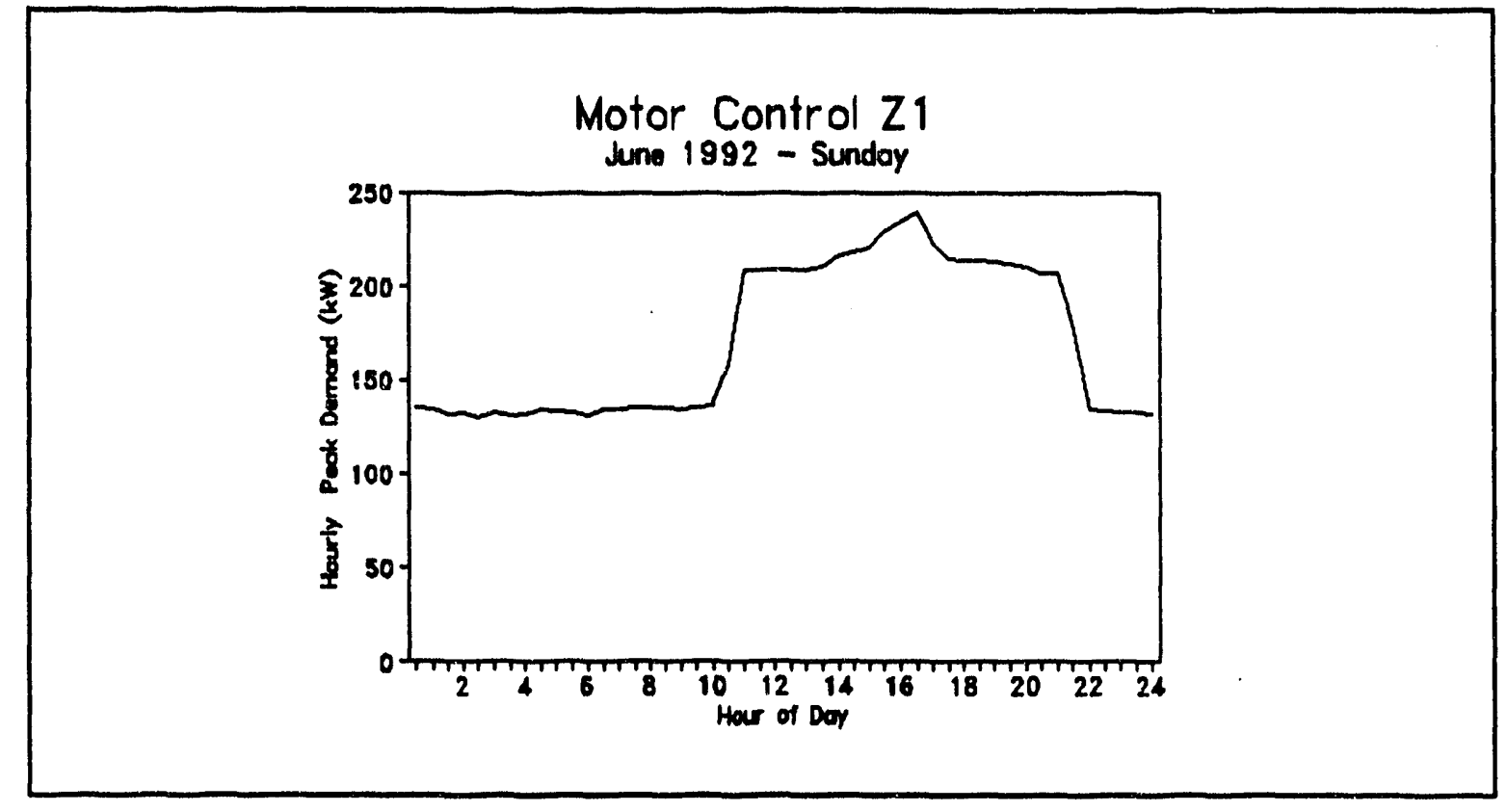

Figure A.3 "Z1" 24-Hour Electricity Demand Profile - Sunday

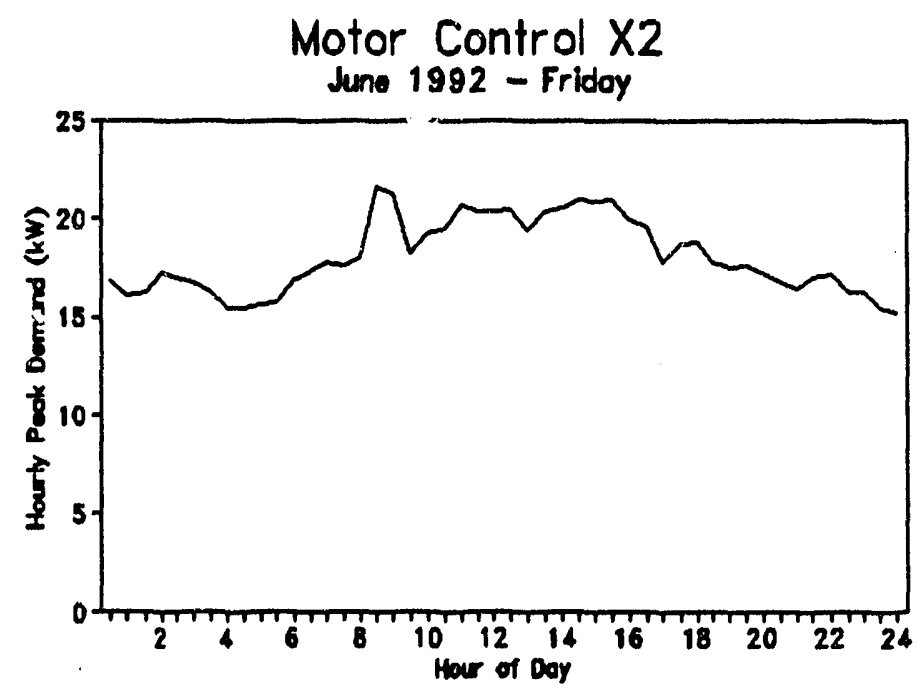

Figure A.4 "X2" 24-Hour Electricity Demand Profile - Friday 


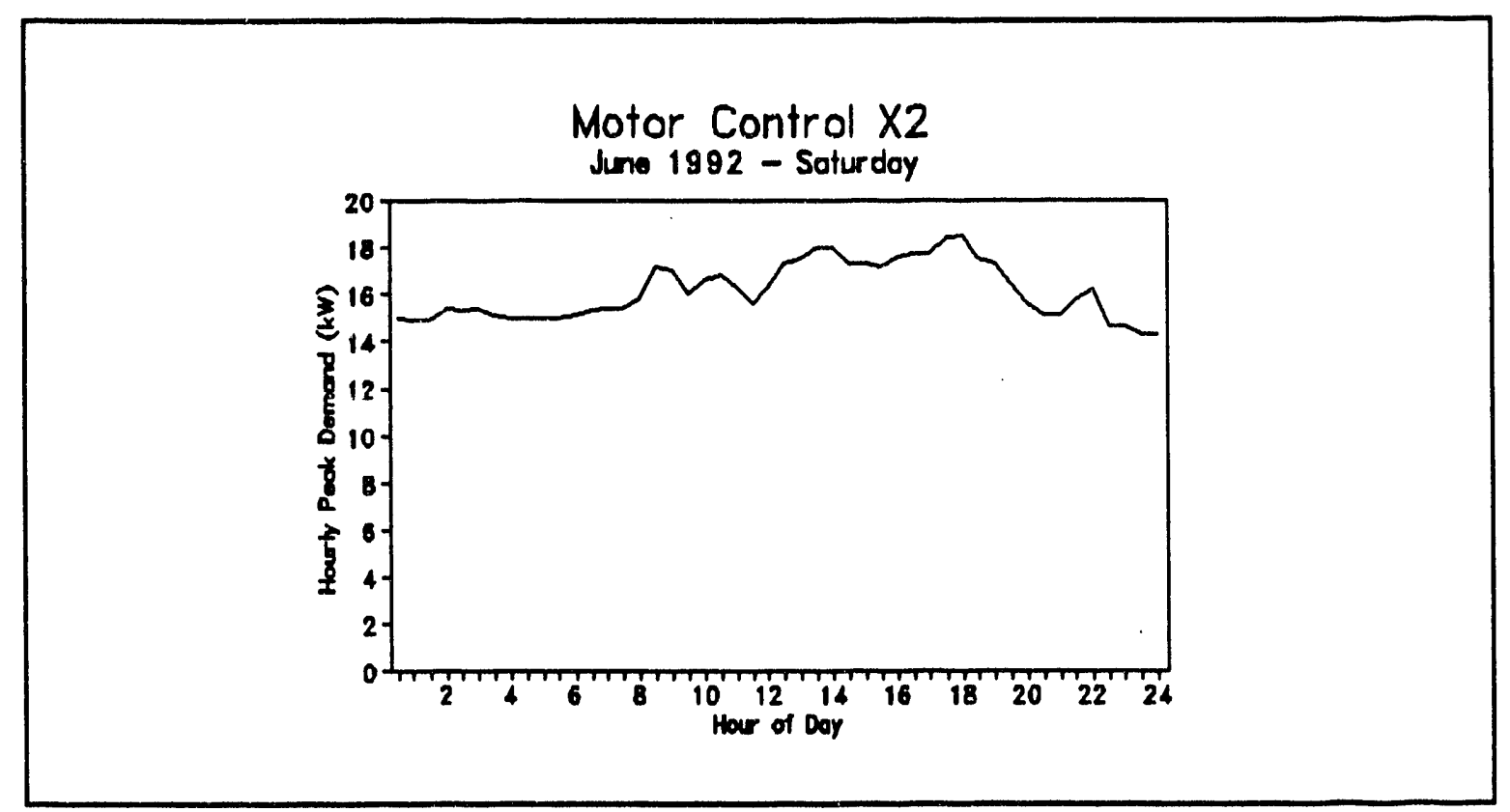

Figure A.5 "X2" 24-Hour Electricity Demand Profile - Saturday

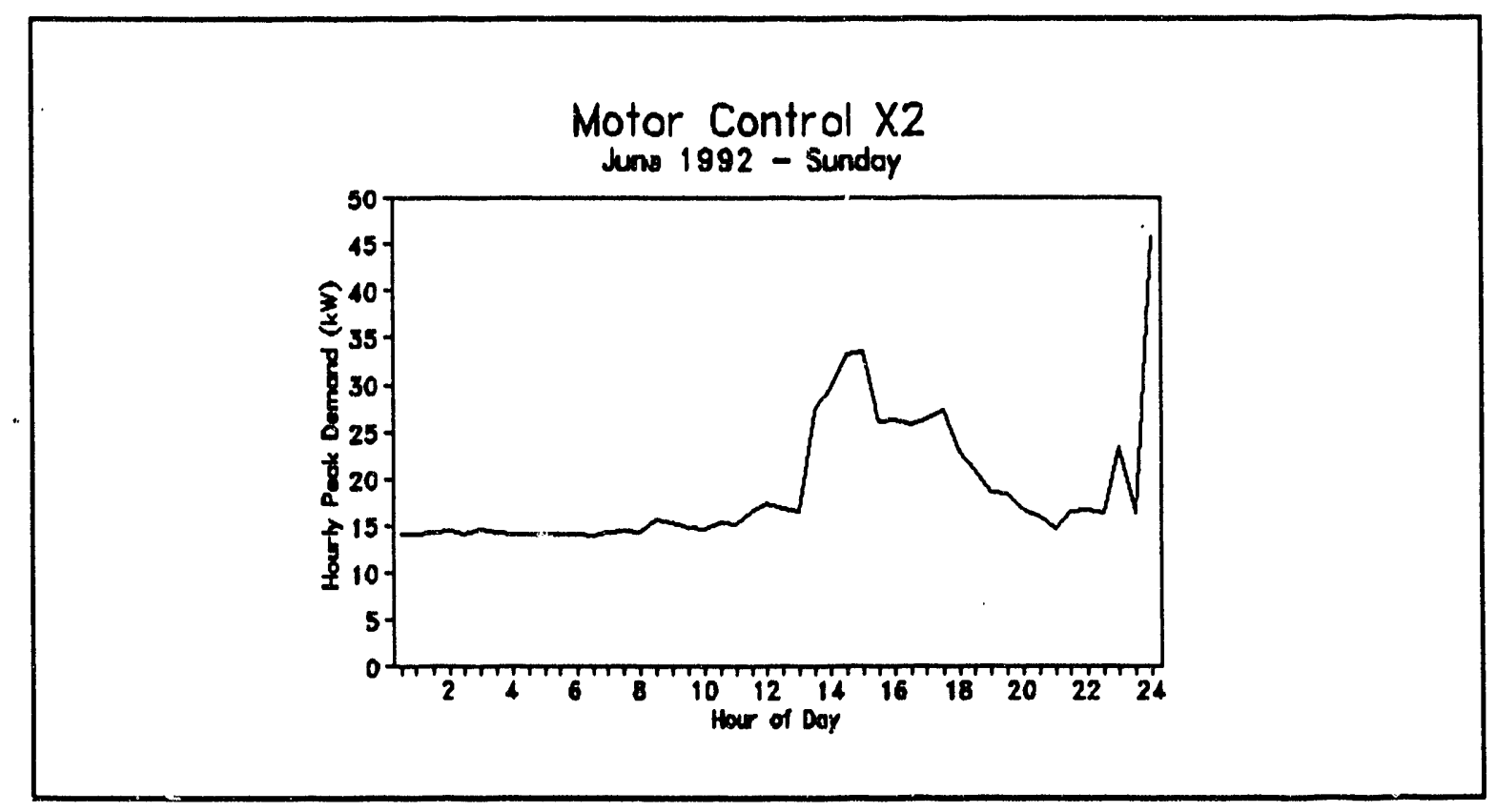

Figure A.6 "X2" 24-Hour Electricity Demand Profile - Sunday 


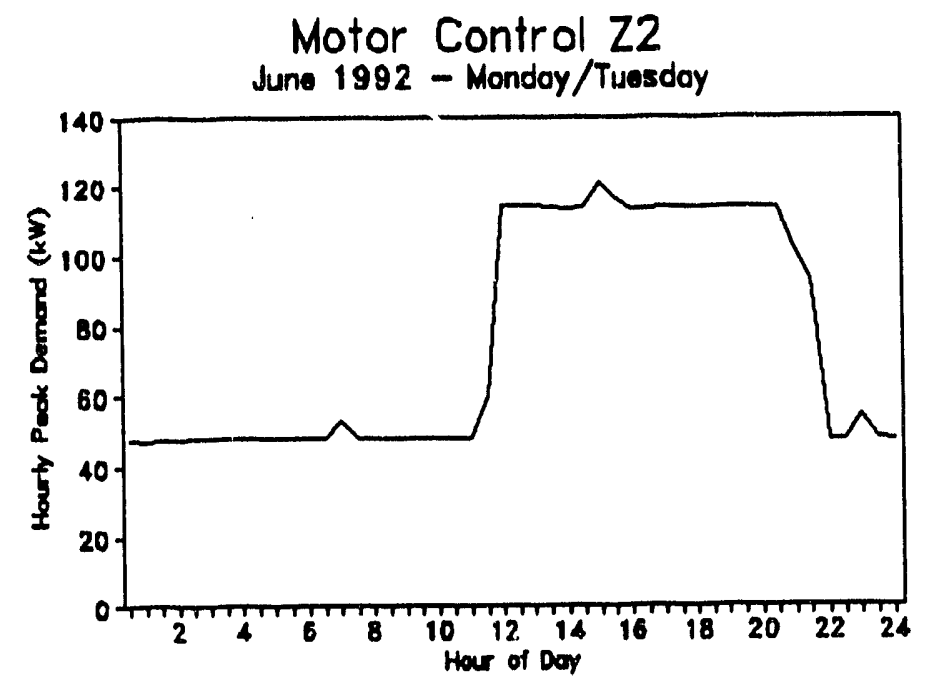

Figure A.7 "Z2" 24-Hour Electricity Demand Profile - Monday/Tuesday

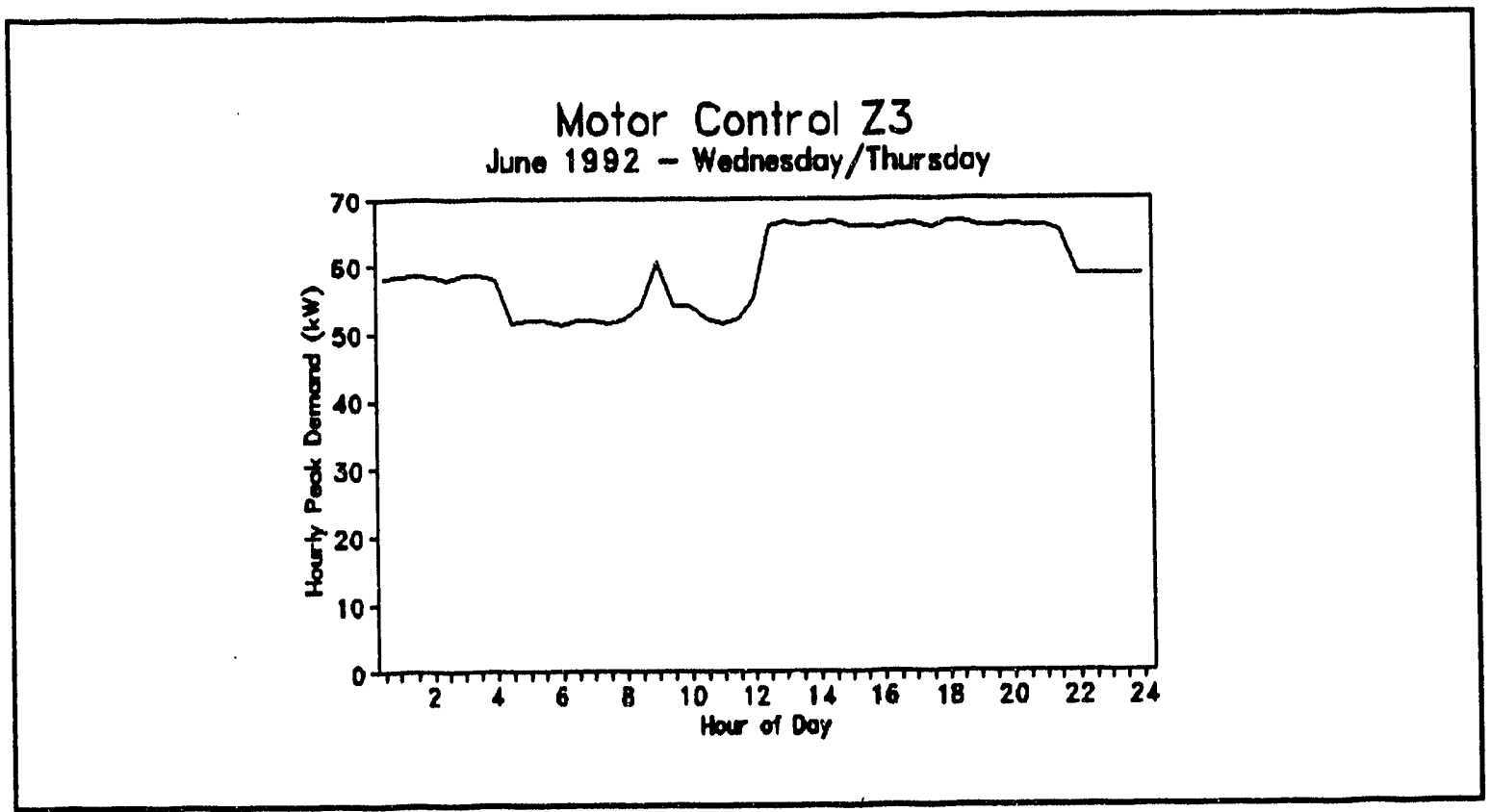

Figure A.8 "Z3" 24-Hour Electricity Demand Profile - Wednesday/Thursday 


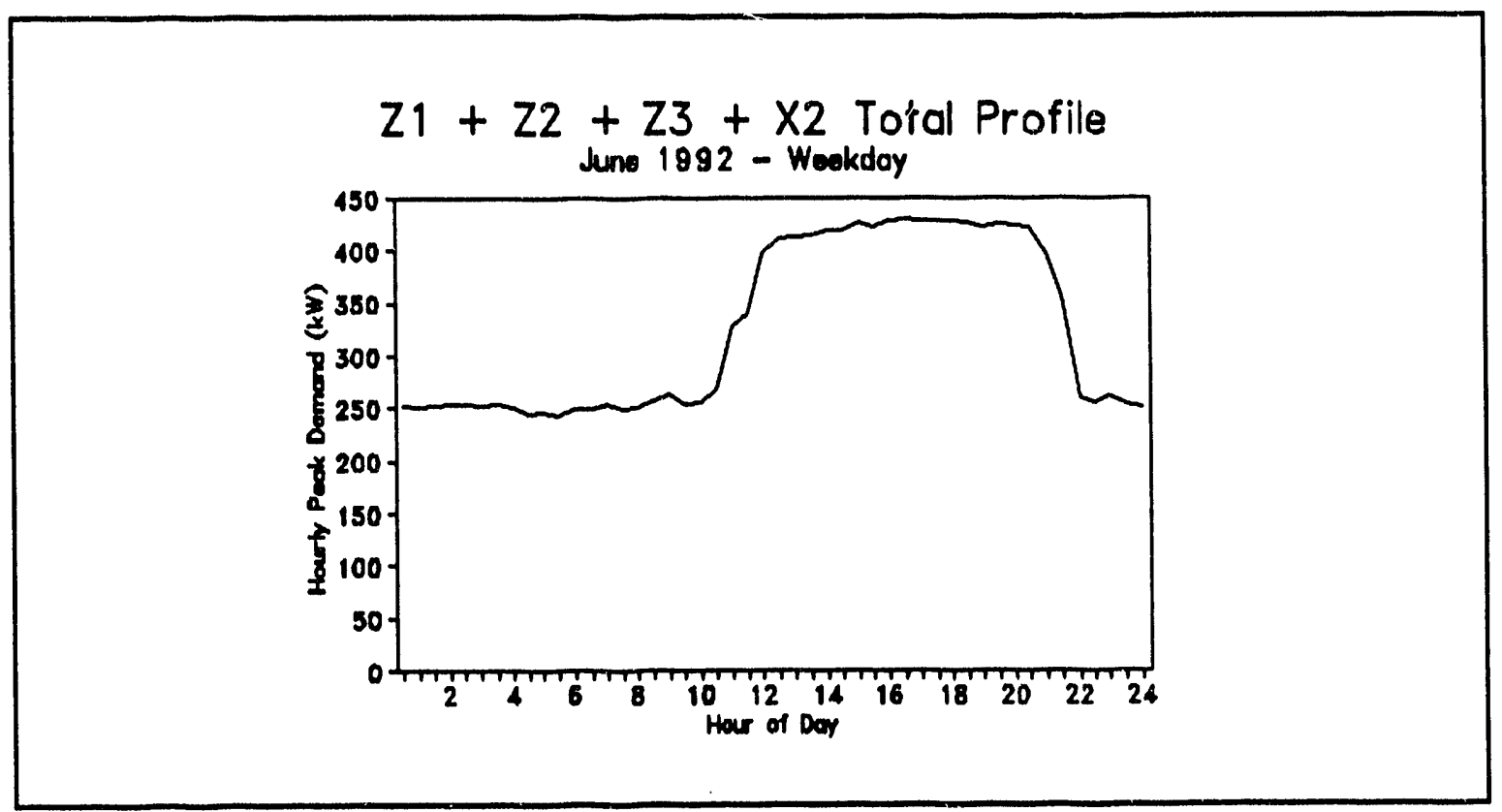

Figure A.9 "Z1" + "Z2" + "Z3" + "X2" 24-Hour Electricity Demand Profile - Weekday

The total demand profile shown in Figure A.9 provides a clear picture of the overall demand profile of the power plant equipment that supports the chiller and boiler operations. Because the equipment operates in direct association with the chillers and boilers, its demand schedule can be considered similar in shape to what might be expected for the chillers and boilers. 


\section{Distribution}

No. of

Copies

\section{Orfsite}

12 DOE/Office of Scientific and Technical Information

2 K. Devine

Federal Energy Management Program

U.S. Department of Energy

CE-10.1

6A-034/FORS

1000 Independence Avenue SW

Washington, DC 20585

2 M. Ginsberg

Federal Energy Management Program

U.S. Department of Energy

CE-44

1000 Independence Avenue SW

Washington, DC 20585

2 L. Harris

Federal Energy Management Program

U.S. Department of Energy

CE-44

1000 Independence Avenue SW

Washington, DC 20585

F. L. Beason

HQ/AFCESA/ENM

139 Barnes Drive

Tyndall AFB, FL 32403-5319

M. Carr

U.S. Department of Defense

Office of Secretary of Defense

DASD (L) EP, The Pentagon

Washington, DC 20301-8000
No. of

Copies

T. Cover

HQ/AMC/CES

507 A Street

Scott AFB, IL 62225-5022

T. Gildersleeve

AFCESA/ENE

139 Barnes Drive

Tyndall AFB, FL 32403-5319

J. Ingram

David Grant Medical Center

Travis AFB, CA 94535

R. K. Hoshide

Rockwell, ETEC

P.O. Box 7930, T038

Canoga Park, CA 91309-7930

Onsite

DOE Ricaland Field Office

D. R. Segna

18 Pacific Northwest Laboratory

R. Bartlett

D. J. Coomes (2)

A. J. Currie

J. W. Currie

A. L. Dittmer

G. B. Parker

R. W. Reilly

E. E. Richman (3)

W. F. Sandusky

Publishing Coordination

Technical Report Files (5)

Distr. 1 

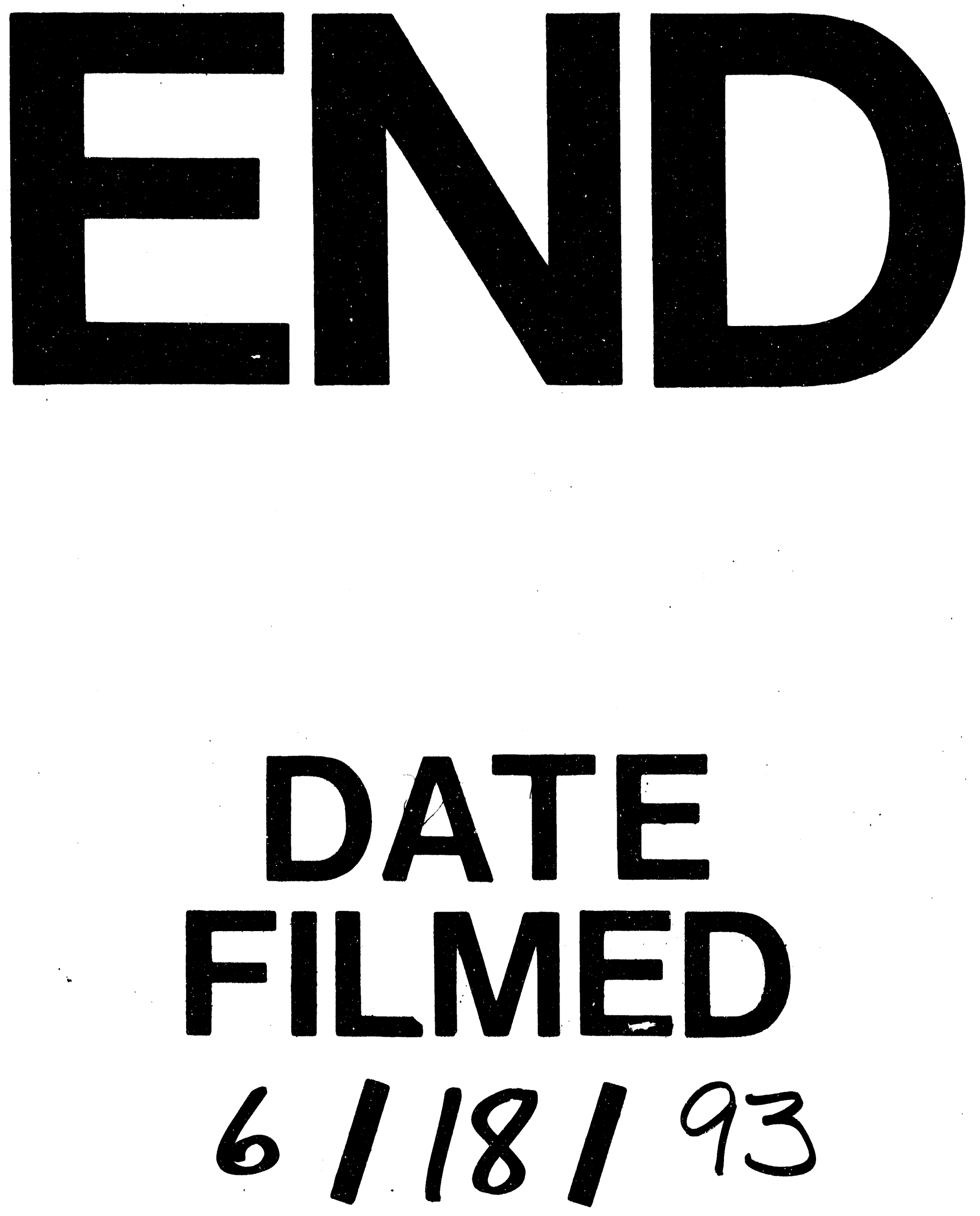
